UNIVERSIDADE DE SÃO PAULO

FACULDADE DE ZOOTECNIA E ENGENHARIA DE ALIMENTOS

ISABELA RODRIGUES DOS SANTOS

Estratégias para conservação de carne armazenada sob refrigeração: embalagem em atmosfera modificada e processamento em alta pressão 


\section{ISABELA RODRIGUES DOS SANTOS}

\section{Estratégias para conservação de carne armazenada sob refrigeração:}

embalagem em atmosfera modificada e processamento em alta pressão

\section{VERSÃO CORRIGIDA}

Dissertação apresentada á Faculdade de Zootecnia e Engenharia de Alimentos da Universidade de São Paulo, como parte dos requisitos para obtenção do título de mestre em Ciências do programa de PósGraduação em Engenharia de Alimentos.

Área de Concentração: Ciências da Engenharia de Alimentos

Orientador: Marco Antonio Trindade 
Dados Internacionais de Catalogação na Publicação

Serviço de Biblioteca e Informação da Faculdade de Zootecnia e Engenharia de Alimentos da Universidade de São Paulo

S237e Estratégias para conservação de carne armazenada sob refrigeração : embalagem em atmosfera modificada e processamento em alta pressão / Isabela Rodrigues dos Santos. -- Pirassununga, 2015.

$115 \mathrm{f}$.

Dissertação (Mestrado) -- Faculdade de Zootecnia e Engenharia de Alimentos - Universidade de São Paulo. Departamento de Engenharia de Alimentos.

Área de Concentração: Ciências da Engenharia de Alimentos.

Orientador: Prof. Dr. Marco Antonio Trindade.

1. Carne bovina 2. Estabilidade 3. Microbiologia 4. Cordeiro 5. Qualidade. I. Título. 
Dedico este trabalho aos meus pais Raimundo Dias e Lourdes Rodrigues, que me ensinaram a nunca desistir. 


\section{AGRADECIMENTOS}

À Deus, por caminhar ao meu lado em cada passo desta história,

Aos meus amados pais, Raimundo e Lourdes, por terem me preparado para enfrentar qualquer dificuldade,

Ao meu irmão, Bruno, que resolveu todos os meus problemas com computadores e outras tecnologias,

À minha vó, Joana, por todo zelo e preocupação,

Ao meu orientador Marco Antonio, que aceitou me orientar e acreditou em mim, antes que eu mesma acreditasse,

À professora Maria Teresa, que se esforçou tanto para me moldar em uma profissional melhor,

Aos meus colegas do laboratório Larissa, Yana, Manoela, Paulo, Juliana Baldin, Julliane Carvalho e Raul, pelo apoio e amizade,

Às minhas IC's Ana Flávia e Monica, por serem meu braço direito,

A todos os técnicos do ZEA, em especial o Fábio, pela disponibilidade em ajudar,

Às minhas queridas amigas da República Catraca Nayla Souki, Beatriz Antunes, Adrielly Ferrinho e Ana Luisa, por fazerem da nossa casa um lar,

À Segunda Igreja Batista em Pirassununga-SP e À Igreja Batista Rosa de Saron em Conceição do Almeida-BA, pelas orações,

À Fundação de Amparo á Pesquisa do Estado de São Paulo, pelo suporte financeiro (Bolsa no país: 2013/07015-3, BEPE: 2014/24412-1, Auxílio à Pesquisa: 2012/20660-2),

À todos que contribuíram para que essa pesquisa se desenvolvesse, sei que somos um grande time. 


\section{RESUMO GERAL}

A busca por produtos mais saudáveis e minimamente processados tem levado indústrias e pesquisadores a estudarem novas formas de preservação de alimentos. Os objetivos deste trabalho foram: 1) avaliar o efeito da embalagem com atmosfera modificada (ATM) na preservação de lombo ovino armazenado sob refrigeração e 2) Avaliar o efeito do processamento em alta pressão na conservação de carne bovina marinada e com teor de sódio reduzido. Em ambas as pesquisas, músculos Longissimus lumborum foram submetidos à contagem microbiana, avaliação de cor, $\mathrm{pH}$, oxidação lipídica (TBARS), perdas por cocção (PPC) e força de cisalhamento. Para o estudo do efeito da embalagem em atmosfera modificada, as amostras foram acondicionadas em cinco sistemas de ATM, $15 \% \mathrm{O}_{2}+85 \% \mathrm{CO}_{2} ; 30 \%$ de $\mathrm{O}_{2}+70 \%$ de $\mathrm{CO}_{2} ; 45 \%$ de $\mathrm{O}_{2}+55 \%$ de $\mathrm{CO}_{2} ; 60 \%$ de $\mathrm{O}_{2}+40 \%$ de $\mathrm{CO}_{2}$ e Vácuo (controle) e armazenadas a $1^{\circ} \mathrm{C}$ durante 21 dias. As análises de cor, $\mathrm{pH}, \mathrm{TBARS}, \mathrm{PPC}$ e força de cisalhamento foram realizadas a cada sete dias e as microbiológicas duas vezes por semana. Diferentes concentrações de oxigênio dentro da embalagem trouxeram diferença significativa na intensidade de cor vermelha das carnes armazenadas em ATM. Até o sétimo dia de estocagem tratamentos com maior quantidade de $\mathrm{O}_{2}$ apresentaram melhor coloração, após esse período embalagens a vácuo conseguiram preservar melhor a mioglobina. Diferentes concentrações gasosas não trouxeram causaram diferença $(\mathrm{p}>0,05)$ no $\mathrm{pH}$ da carne entre tratamentos. Nenhuma diferença significativa entre tratamentos foi encontrada para amostras embaladas em ATM nos parâmetros perda de peso por cocção e força de cisalhamento. A embalagem em atmosfera modificada foi capaz de retardar o crescimento da microbiota presente na carne. Isso levou á preservação da amostra por até 18 dias sob refrigeração, enquanto amostras a vácuo tiveram uma vida útil de 11 dias. Para o estudo do efeito da alta pressão em carne marinada com baixo teor de sódio, 
as carnes foram inoculadas com $10^{6} \mathrm{UFC} / \mathrm{g}$ de carne com E. faecium e Listeria innocua e em seguida marinadas durante 18 horas, a $4^{\circ} \mathrm{C}$, em diferentes soluções: $1 \% \mathrm{NaCl}+$ $1 \%$ ácido cítrico, $1 \% \mathrm{NaCl}+2 \%$ ácido cítrico, $2 \% \mathrm{NaCl}+2 \%$ ácido cítrico e $2 \% \mathrm{NaCl}$ $+2 \%$ ácido cítrico. Após a marinação as amostras foram submetidas ao tratamento nas seguintes pressões: Zero (controle), 300MPa, 450Mpa, 600MPa. As análises físicoquímicas e microbiológicas foram realizadas logo após o tratamento. O tratamento em alta pressão foi capaz de reduzir a população microbiana em até seis ciclos logarítmicos quando 600Mpa foram aplicados em todas as soluções estudadas. A não aplicação de alta pressão proporcionou a redução de apenas um ciclo log na população de E. faecium quando as carnes foram marinadas $\operatorname{com} 2 \% \mathrm{NaCl}+2 \%$ ácido cítrico. A alta pressão e as diferentes concentrações de sal e ácido, não trouxeram diferença significativa na coloração das amostras. Já o maior teor de ácido cítrico na marinada causou maior $(\mathrm{p}<0,05)$ redução do $\mathrm{pH}$ da carne em comparação com as amostras em baixa concentração de ácido. Os experimentos demonstraram que a tanto embalagem a vácuo quanto a aplicação de ácido cítrico foram eficientes em retardar a oxidação lipídica. Pressões de 600Mpa tornaram a carne significativamente mais dura que as demais pressões aplicadas. Os resultados demonstraram a possibilidade de extensão da vida útil da carne refrigerada através da aplicação de diferentes tecnologias: a embalagem com atmosfera modificada para carne fresca e processamento em alta pressão de carnes marinadas com reduzido teor de sal.

Palavras-chave: Carne bovina, estabilidade, microbiologia, cordeiro, qualidade. 


\begin{abstract}
The seek for healthier and minimally processed foods has led industries and researchers to study new forms of food preservation. The objective of this project was 1) to evaluate the effect of modified atmosphere packaging (MAP) in the preservation of lamb loin stored under refrigeration and 2) to evaluate the effect of high pressure on the conservation of marinated beef with reduced sodium content. In both cases, Longissimus lumborum muscles were submitted to microbial count, color evaluation, $\mathrm{pH}$, lipid oxidation (TBARS), cooking losses (CL) and shear force. To study the effect of modified atmosphere packaging, the samples were placed into five MAP systems, $15 \% \mathrm{O}_{2}+85 \% \mathrm{CO}_{2} ; 30 \% \mathrm{O}_{2}+70 \% \mathrm{CO}_{2} ; 45 \% \mathrm{O}_{2}+55 \% \mathrm{CO}_{2} ; 60 \% \mathrm{O}_{2}+40 \% \mathrm{CO}_{2}$ and vacuum (control) and stored at $1{ }^{\circ} \mathrm{C}$ for 21 days. The color, $\mathrm{pH}$, TBARS, CL and shear force analyzes were performed every seven days and microbiological loads counted twice a week. Different concentrations of oxygen in the headspace brought significant difference in the redness of samples packed in ATM. Until the seventh day of storage the treatments with higher concentration of $\mathrm{O}_{2}$ showed a better color, thereafter vacuum packaging managed to best preserve the myoglobin. Different gas concentrations have not brought significant difference $(\mathrm{p}>0.05)$ in the $\mathrm{pH}$ of the meat among treatments. No significant difference among treatments was found for samples packed in ATM for cooking loses and shear force parameters. The modified atmosphere packaging was able to retard the growth of microbial flora on meat. This led to the preservation of the sample for up to 18 days under refrigeration, while samples in vacuum had a shelf life of only 11 days. To evaluate the effect of high pressure in marinated meat, the steaks were inoculated with $106 \mathrm{CFU} / \mathrm{g}$ of meat with E. faecium and Listeria innocua and then marinated for 18 hours at $4^{\circ} \mathrm{C}$ in different solutions: $1 \% \mathrm{NaCl}+1 \%$ citric acid, $1 \%$ $\mathrm{NaCl}+2 \%$ citric acid, $2 \% \mathrm{NaCl}+2 \%$ citric acid and $2 \% \mathrm{NaCl}+2 \%$ citric acid. After
\end{abstract}


marination, samples were subjected to the following pressures: $600 \mathrm{MPa}, 450 \mathrm{MPa}$, 300MPa and 0MPa (control). The physicochemical and microbiological analyzes were conducted soon after treatment. The high pressure treatment was able to reduce six log cycles of the microbial population when $600 \mathrm{MPa}$ was applied to all solutions studied. Without high pressure application, the reduction was only of 1 log cycle in the population of $E$. faecium when the samples were marinated with $2 \% \mathrm{NaCl}+2 \%$ acid. The high pressure and different sodium and acid concentrations did not bring difference in the color of the samples. Higher citric acid content in the marinade caused higher ( $\mathrm{p}$ $<0.05)$ reduction of the $\mathrm{pH}$ of the meat, compared with samples of low concentration of acid. In order to slow down lipid oxidation, the experiments demonstrated that both vacuum packaging and citric acid are efficient implementation. The application of $600 \mathrm{MPa}$ made the meat significantly tougher than the meat treated with other pressures. The results demonstrated the possibility of extending the shelf-life of the chilled meat by applying different technologies: modified atmosphere packaging for fresh meat and marination of meat with reduced salt content by high pressure use.

Keywords: Beef, stability, microbiology, lamb, quality. 


\section{LISTA DE FIGURAS}

Figura 1 - Reações da mioglobina para formação de quatro produtos responsáveis pela coloração da carne 28

Figura 2 - Variação do teor de oxigênio dentro das embalagens durante o período de estocagem refrigerada.

Figura 3- Variação do teor de oxigênio dentro das embalagens durante o período de estocagem refrigerada

Figura 4- - Variação do valor de $L^{*}$ de lombos de cordeiro armazenados em atmosfera modificada e armazenados sob refrigeração.30 min após a abertura da embalagem durante todo o período de estocagem. 70

Figura 5- Variação do valor de $\mathrm{a}^{*}$ de lombos de cordeiro armazenados em atmosfera modificada e armazenados sob refrigeração.30 min após a abertura da embalagem durante todo o período de estocagem.

Figura 6- Lombos de cordeiros após 30 minutos de exposição ao ar atmosférico no primeiro dia de estocagem a $1^{\circ} \mathrm{C}$.

Figura 7- Lombos de cordeiros após 30 minutos de exposição ao ar atmosférico no décimo quarto dia de estocagem a $1^{\circ} \mathrm{C}$. 72

Figura 8- Curva representativa da variação de $\mathrm{pH}$ de lombos de cordeiro armazenados em atmosfera modificada e armazenados sob refrigeração.

Figura 9- Índice de TBARS de lombos de cordeiro armazenados em atmosfera modificada e armazenados sob refrigeração, durante o período de estocagem

Figura 10- Força de cisalhamento de lombos de cordeiro armazenados em atmosfera modificada e armazenados sob refrigeração, medidas durante todo o período de estocagem. 
Figura 11- Curva de crescimento de bactérias lácticas de lombos de cordeiro armazenados em atmosfera modificada e armazenados sob refrigeração.

Figura 12- Curva de crescimento de psicrotróficos anaeróbicos de lombos de cordeiro armazenados em atmosfera modificada e armazenados sob refrigeração 79

Figura 13- Curva de crescimento de psicrotróficos aeróbicos de lombos de cordeiro armazenados em atmosfera modificada e armazenados sob refrigeração 80

Figura 14- Máquina seladora utilizada na embalagens das amostras 92

Figura 15- Equipamento utilizado para processamento em alta pressão das amostras. 


\section{LISTA DE TABELAS}

Tabela 1 - Medidas de gramatura e espessura para os filmes alta barreira empegados no acondicionamento de lombos de cordeiro aramazenados sob refrigeração.

Tabela 2 - Composição centesimal do lombo de cordeiro $(\% \mathrm{~m} / \mathrm{m})$ .66

Tabela 3 - Resultado do teste afetivo para amostras de todos os tratamentos no segundo dia de estocagem refrigerada

Tabela 4 - Resultado do teste afetivo para amostras de todos os tratamentos no nono dia de estocagem refrigerada 82

Tabela 5 - Resultado do teste visual de ordenação de preferência para amostras de todos os tratamentos nos tempos 2 dias e 9 dias de estocagem.

Tabela 6 - Concentrações de sal e ácido cítrico em marinadas aplicadas nas amostras de carne 91

Tabela 7 - Resultados das contagens de E. faecium (Log10 UFC / g) de amostras de carne submetidas a diferentes níveis de HPP, sal e ácido cítrico 96

Tabela 8 - Resultados das contagens de Listeria innocua (log CFU / g) de amostras de carne submetidos a diferentes níveis de HPP, sal e ácido cítrico. 97

Tabela 9 - Os valores de $\mathrm{pH}$ para os diferentes tratamentos e pressões 98

Tabela 10 - Valores de $\mathrm{L} *$ para todas as amostras de lombo marinado em diferentes soluções e tratados em diferentes pressões.

Tabela 11 - Comparação entre valores $L$ * para as amostras tratadas com 600 MPa no momento inicial e final do armazenamento. 99

Tabela 12 - Intensidade e vermelho (a*) medido para lombo bovino marinado com diferentes soluções e tratados com diferentes pressões 100 
Tabela 13 - Comparação entre os valores a * para as amostras tratadas com 600 MPa no momento inicial e final do armazenamento. 101

Tabela 14 - Intensidade de cor amarela (b*) medida para lombo bovino marinado com diferentes soluções e tratados com diferentes pressões 101

Tabela 15 - Comparação entre valores de a * para as amostras tratadas com 600 MPa no momento inicial e final do armazenamento. 102

Tabela 16 - Valores de TBARS das amostras de lombo bovino marinado em soluções com diferentes concentrações de sal e ácido cítrico e tratados com diferentes pressões. 103

Tabela 17 - Comparação entre os valores de TBARS (malonaldeído mg kg- ${ }^{1}$.) Para amostras tratadas com $600 \mathrm{MPa}$ no momento inicial e final do armazenamento. 103

Tabela 18 - Porcentagem de perda de peso por cocção para lombo bovino marinado em diferentes concentrações de sal e ácido cítrico e submetido a diferentes pressões.

Tabela 19 - Comparação entre os valores de perda por cocção para amostras tratadas com $600 \mathrm{MPa}$ no momento inicial e final do armazenamento. 105

Tabela 20 - Valores da força de cisalhamento de lombo bovino marinado em diferentes soluções e tratados com diferentes níveis de pressão. 106

Tabela 21 - Comparação entre os valores de força de cisalhamento para amostras tratadas com $600 \mathrm{MPa}$ no momento inicial e final do armazenamento. 106

Tabela 22 - Valores do teor de sódio medido em contrafilé bovino in natura e marinado com diferentes soluções. 107 


\section{SUMÁRIO}

CAPÍTULO 1. REVISÃO DE LITERATURA

1. Revisão de literatura

1.1 Mercado de Carnes

1.1.1 O mercado de carne ovina

1.1.2 O mercado de carne bovina

1.2 Características da Carne

1.3 Aspectos Sensoriais

1.4 Fatores de deterioração

1.5 Sódio em alimentos 35

1.6 Estratégias de conservação de carnes e produtos cárneos .36

1.6.1 Embalagens em atmosfera modificada.... .36

1.6.2 Marinação 39

1.6.3 Alta Pressão 42

REFERÊNCIAS. 46

2. EFEITO DA TECNOLOGIA DE ATMOSFERA MODIFICADA SOBRE A QUALIDADE DA CARNE DE CORDEIRO REFRIGERADA................................ 53

2.1 INTRODUÇÃO .57

2.2 MATERIAIS E MÉTODOS .59

2.2.1 Matérias primas .59

2.2.2 Caracterização da embalagem. .59 


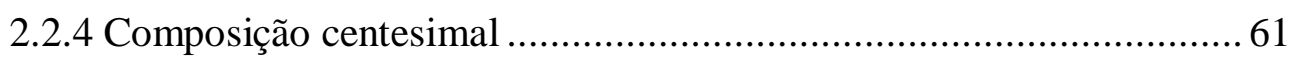

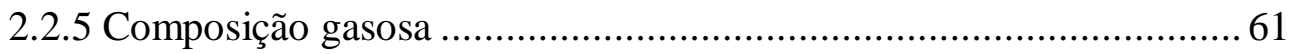

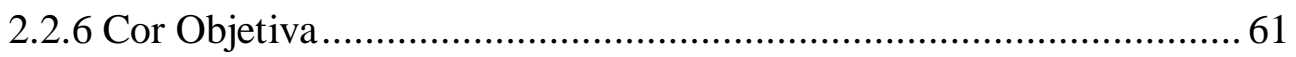

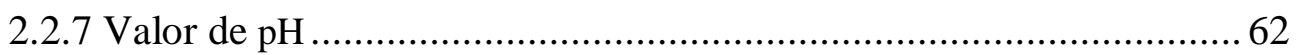

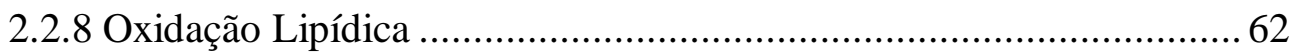

2.2.9 Perda de peso por cocção e Força de cisalhamento .......................... 62

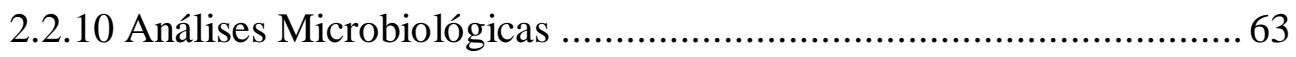

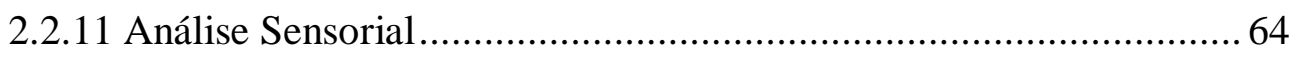

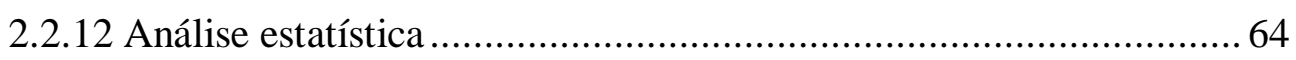

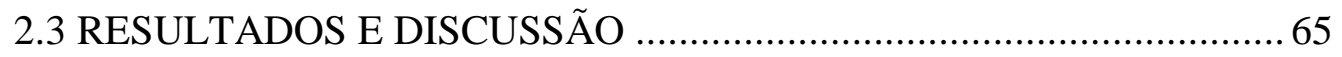

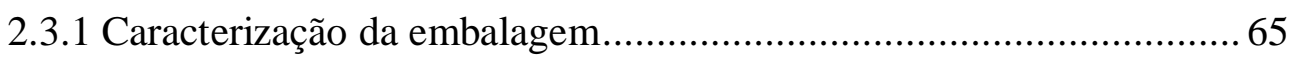

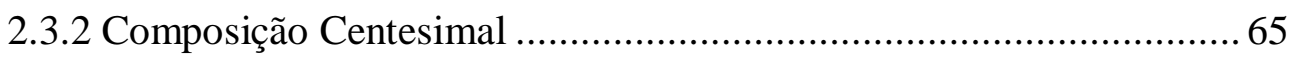

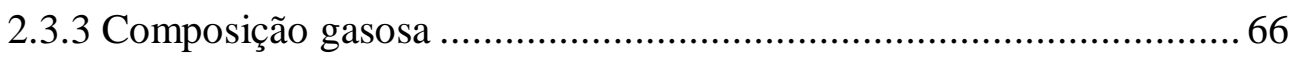

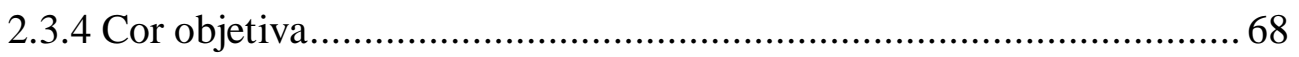

2.3.5 Potencial hidrogênionico - $\mathrm{pH}$............................................... 72

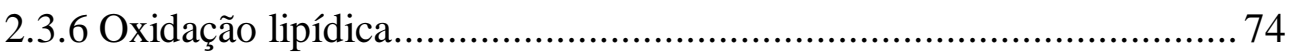

2.3.7 Perda de peso por cocção e força de cisalhamento ........................... 76

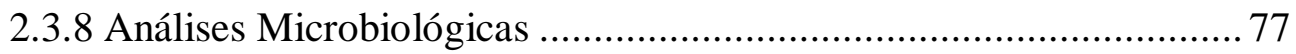

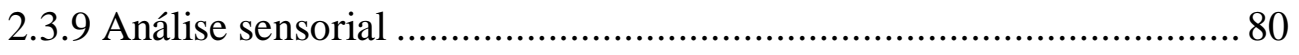

2.4 CONCLUSÃO

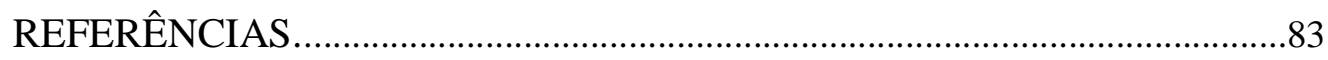


3. EFEITO DO PROCESSAMENTO EM ALTA PRESSÃO SOBRE PROPRIEDADES FISICO-QUÍMICAS E MICROBIOLÓGICAS DE CARNE BOVINA MARINADA COM REDUZIDO TEOR DE SAL ..................................... 87

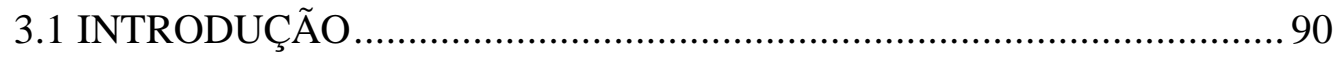

3.2 MATERIAIS E MÉTODOS …...................................................... 91

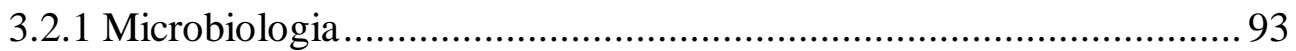

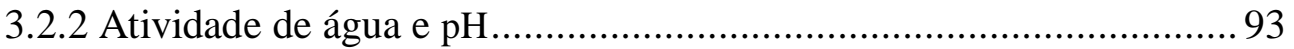

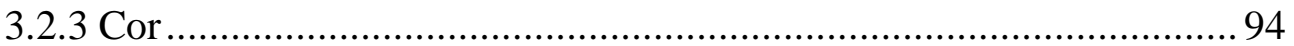

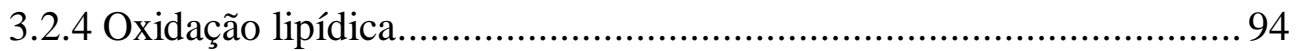

3.2.5 Perdas por cocção e força de cisalhamento ..................................... 94

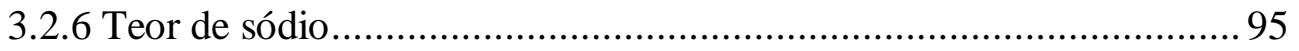

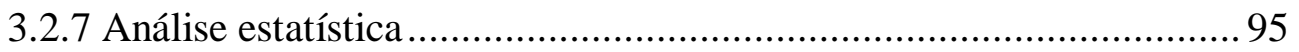

3.3 RESULTADOS E DISCUSSÃO .................................................... 95

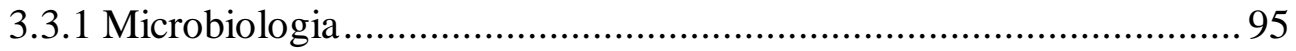

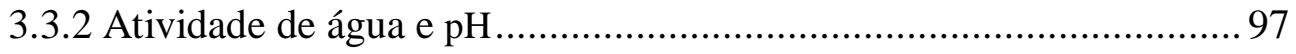

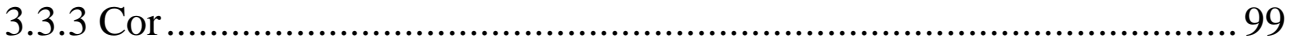

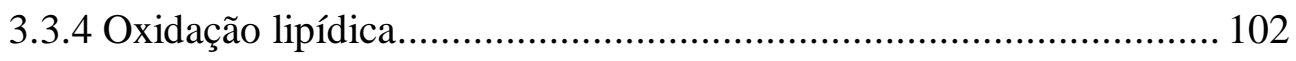

3.3.5 Perda de peso no cozimento e força de cisalhamento ..................... 104

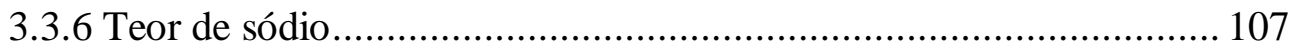

3.4 CONCLUSÃO....................................................................... 108

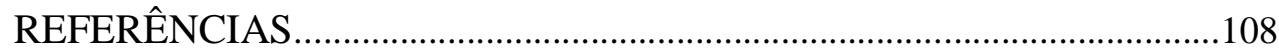

ANEXO A- Ficha com escala hedônica utilizada no teste de aceitação.........111 
ANEXO B- Ficha de Ordenação de Preferência.................................................112

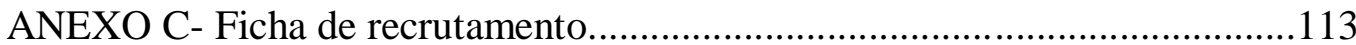




\section{INTRODUÇÃO}

De acordo com Machado (2009) os processos utilizados para conservação da carne são uma prática bastante antiga e são fundamentais para a extensão da vida de prateleira tanto da carne fresca quanto de produtos cárneos. Dentre as metodologias empregadas (salga, desidratação, processamentos térmicos e não térmicos, congelamento e resfriamento) o congelamento tem sido largamente utilizado, pois além de possibilitar a conservação da carne por meses, preserva suas características químicas, sensoriais e nutricionais próximas às iniciais.

Entretanto a busca por alimentos de conveniência tem elevado a preferência dos consumidores por carnes resfriadas (TRINDADE, et al. 2013). Neste contexto a correta seleção da técnica de conservação associada ao resfriamento pode contribuir para o aumento da vida útil destes produtos.

As embalagens, de forma geral, têm como função proteger os produtos contra a descoloração, o desenvolvimento de off-flavors, a perda de nutrientes e a mudança de textura, além dificultar o crescimento de microrganismos deterioradores e patogênicos (MCMILLIN, 2008).

O processamento com alta pressão (HPP) é uma das tecnologias mais recentes que têm mostrado grande potencial de aplicação na fabricação de produtos cárneos (GROSSI et al., 2012), principalmente devido a exigência crescente do consumidor por alimentos processados que são semelhantes às respectivas matérias-primas em termos de cor, sabor e textura (CREHAN, TROY, BUCKLEY, 2000).

O objetivo deste trabalho foi avaliar a aplicação de diferentes técnicas de conservação na carne resfriada. Para isso foram testadas diferentes condições de embalagem para carne ovina em atmosfera modificada e a aplicação do processamento 
em alta pressão em carne bovina marinada com soluções em diferentes concentrações de $\mathrm{NaCl}$ e ácido cítrico. 
CAPÍTULO 1. REVISÃO DE LITERATURA 


\section{REVISÃO DE LITERATURA}

\subsection{MERCADO DE CARNES}

A ultima década tem sido marcada por importantes mudanças no cenário dos consumidores de carne, os quais estão mais informados e mais exigentes. As indústrias tiveram que se adaptar a este novo perfil de consumidores que estão conscientes quanto à saudabilidade do alimento e exigem produtos de alta qualidade, a fim de sobreviver em um mercado extremamente competitivo (HOFFMAN et al., 2006).

\subsubsection{O mercado de carne ovina}

A criação de ovinos e caprinos é uma atividade bastante antiga. A China é o país que possui o maior rebanho, com 134 milhões de cabeças, e a Nova Zelândia é o maior exportador mundial, atendendo a 55\% do mercado, com 31 milhões de cabeças (CORRÊA, 2012).

Segundo Firetti et al. (2010), a falta de informações confiáveis sobre o consumo e o abate de ovinos no Brasil desfavorece o investimento e expansão desse deste ramo da pecuária no país. Isso ocorre devido a fatores relacionados à forma de criação dos animais e má qualidade do produto destinado à venda, os quais afetam negativamente a estruturação da ovinocultura no Brasil, apesar do potencial de crescimento dessa atividade (REIS, 2009).

O consumo per capita de carne ovina no Brasil é de apenas 400 gramas por pessoa ao ano, quantidade bastante inferior a de outros tipos de carne, como a de aves que chega a 43,4 quilos por ano, a bovina, que é de 37,4 quilos e a suína, que é de 14,1 quilos por ano. O sistema e a escala de produção adotados no Brasil, o número de abates clandestinos e o preço, são alguns fatores que prejudicam o crescimento da atividade no 
país (REIS, 2009). Isso gera irregularidade na oferta do produto colaborando ainda mais com a falta de hábito de consumo pela população. As carnes que chegam ao mercado têm ainda problemas de má qualidade e má apresentação, em razão de boa parte vir do abate clandestino (CORRÊA, 2012). Uma pesquisa realizada por Firetti et al. (2010) com consumidores de carne ovina no estado de São Paulo, demonstrou que $88 \%$ dos participantes da pesquisa indicaram gostar da carne ovina, mas 40,9\% dessa população consumiam a carne apenas uma ou duas vezes por ano. De acordo com essa pesquisa $31,2 \%$ dos entrevistados estavam insatisfeitos com a embalagem do produto e $40,7 \%$ indicaram insatisfação com os locais de aquisição da carne. Além disso, 74,1\% dos consumidores consideraram o preço da carne ovina mais elevado do que o da carne de consumo preferencial.

A importância da criação de ovinos no Brasil é de cunho social e econômico, principalmente para a população rural nas regiões onde ela é desenvolvida. O Brasil produz animais de 26 raças, e por isso ele é considerado o melhor produtor de material genético do mundo (VIEGAS, 2012). Embora esta atividade não seja representativa, quando comparada com a criação de bovinos, por exemplo, ela é uma alternativa viável e sustentável para a diversificação da produção, principalmente para os pequenos e médios produtores (NOGUEIRA FILHO, 2006). Além disso, o Brasil possui condições climáticas e geográficas favoráveis à produção de ovinos. As regiões centro-oeste e norte foram as que apresentaram maior crescimento em 2010, $12,4 \%$ e $7,1 \%$ respectivamente. Nesse mesmo ano o efetivo de ovinos em todo o país foi de 17.380.581 animais, estando a maior parte deles concentrada na região nordeste, $56,7 \%$ de todo o efetivo nacional (MARSIGILIO, 2012). 


\subsubsection{O mercado de carne bovina}

Diferentemente da carne ovina, o mercado de carne bovina é bastante consolidado no Brasil. Segundo dados da Associação Brasileira das Indústrias Exportadoras de Carne (ABIEC) (2015), de janeiro a outubro o país exportou mais de quatro milhões de dólares em carne bovina. A principal forma de comercialização é a carne in natura, responsável por $78 \%$ das vendas. O Ministério da Agricultura prevê que até 2020 o Brasil suprirá até 44,5\% do mercado mundial.

Em 2015 o maior exportador mundial foi a Índia, seguida do Brasil. A Rússia é o país que mais importa esse tipo de carne (USDA, 2015). O aumento do consumo cresce com base em três fatores: aumento da população, da renda per capita e urbanização. Devido a isso, espera-se que o maior crescimento no consumo de carne bovina ocorra em países emergentes (CAVALCANTI, 2008).

De acordo com Henchion et al. (2014), fatores como renda e preço estão perdendo influência na decisão de compra de carne, enquanto outros fatores como a qualidade, estão se tornando cada vez mais importantes. Os consumidores estão exigindo produtos prazerosos, seguros e saudáveis.

Apesar da comercialização de carne bovina no Brasil ocorrer em sua maioria na forma in natura, percebe-se, principalmente nos países desenvolvidos, uma crescente busca por inovações no setor de carnes. A maior parte das inovações está relacionada com a demanda dos consumidores por alimentos mais saudáveis, com reduzido teor de sódio, gordura e nitrito (CHAMORRO, 2012). 


\subsection{CARACTERÍSTICAS DA CARNE}

A unidade estrutural que constitui o músculo é a fibra muscular, a qual é composta basicamente por miofibrilas separadas por uma rede de túbulos, o retículo sarcoplasmático (LAWRIE, 2005). A qualidade da carne é definida por uma série de fatores que englobam aspectos pré e pós abate (HOFFMAN et al., 2003). Segundo Trindade e Gressoni Júnior (2008), após o abate dos animais o músculo sofre diversas reações químicas, físicas e bioquímicas que dão origem à carne. Nas primeiras $24 \mathrm{~h}$ ocorrem as reações que formarão a maior parte das características e propriedades deste alimento, um exemplo é a conversão do glicogênio em ácido láctico, levando á queda do pH. Segundo Hopkins, Fogarty e Mortimer (2011) fatores genéticos, tais como cruzamentos, podem afetar parâmetros de qualidade, como maciez, suculência, teor de gordura intramuscular, $\mathrm{pH}$ e cor.

Do ponto de vista nutricional, a carne é valorizada pela sua riqueza em aminoácidos essenciais, além de ser fonte de vitaminas, sais minerais e outros elementos nutritivos (LAWRIE, 2005). De acordo com Pardi (1993), as proteínas da carne são digestíveis em 95-100\%, enquanto as vegetais o são em apenas $65-70 \%$. Na fisiologia, independente de seu valor plástico e energético, as proteínas são necessárias na formação de enzimas, hormônios e hemoglobina. Elas participam ainda da regulação do metabolismo hídrico, da determinação do $\mathrm{pH}$ dos diversos tecidos e do processo de imunidade natural às infecções.

As proteínas estão presentes no músculo na proporção de 16 a $22 \%$ da massa muscular, e elas podem ser classificadas em sarcoplasmáticas, miofibrilares e do tecido conjuntivo, dependendo da sua solubilidade em água. As proteínas sarcoplasmáticas estão presentes no suco da carne e proporcionam sua cor. São exemplos de proteínas sarcoplasmáticas, o miogênio, a mioglobulina, a mioglobina e a hemoglobina; as duas 
últimas respondem por 25 a $30 \%$ do total. Dentre as proteínas miofibrilares as mais importantes são a miosina e a actina. A primeira representa $38 \%$ do conteúdo protéico do músculo e a segunda, aproximadamente 15\%; ambas podem se unir formando a actomiosina durante a contração muscular. O colágeno e a elastina são proteínas do tecido conjuntivo, sendo o colágeno considerado principal componente, apresentando-se na proporção de 1 a 2\% (PARDI, 1993).

Os lipídios da carne encontram-se armazenados basicamente de três formas, extracelular, intermuscular e intramuscular. Os extracelulares e intermusculares podem ser observados na superfície da carne, enquanto o intramuscular faz parte do tecido que constitui os músculos na forma de fibras. A gordura intramuscular e intermuscular é conhecida como marmoreio, sua proporção varia de acordo com a espécie do animal, raça e músculo. Carnes magras possuem um teor de gordura que varia entre $0,5 \%$ e $10 \%$ (PARDI, 1993). Prata (1999) informa que o teor de gordura em ovinos é de 4\%, sendo a maior parte constituída por ácidos graxos saturados ou monoinsaturados.

Os principais componentes dos lipídios são o glicerol e os ácidos graxos. O glicerol forma os triglicerídeos que predominam na gordura da carne. Os ácidos graxos saturados encontrados com maior frequência em carnes são o palmítico e o esteárico; dos insaturados, o ácido oleico é o principal (XIMENES, 2010). Leão et al. (2011) afirmam que na carne ovina os ácidos graxos saturados mais encontrados são o mirístico (C14:0), o palmítico (C16:0) e esteárico (C18:0); e os monoinsaturados mais frequentes são o palmitoleico (C16:1 $\omega 7)$ e oleico $(\mathrm{C} 18: 1 \omega 9)$.

Geralmente, a substituição de parte dos grãos por feno na dieta dos cordeiros favorece maior deposição de ácidos graxos poliinsaturados no tecido muscular dos animais, o que possibilita a obtenção de carnes de melhor qualidade nutricional (XIMENES, 2010). 
Normalmente, o aumento da maturidade fisiológica dos ruminantes causa diminuição dos níveis de ácidos graxos saturados no músculo, o que pode ser devido ao aumento da atividade da enzima delta- 9- desturase, a qual promove maior produção de ácido oleico em detrimento do esteárico (DÍAZ et al.,2009).

O genótipo também exerce grande influência na qualidade da carne de ovinos. Ximenes (2010) cita pesquisas relacionadas à avaliação da composição de ácidos graxos em carnes de raças britânicas e espanholas, sendo observada uma maior quantidade em raças espanholas.

Os glicídios são carboidratos que exercem a função de energéticos na atividade muscular. Na carne, eles desempenham um papel importante relacionado ao $\mathrm{pH}$. O principal glicídio presente na carne é o glicogênio, mas também há açúcares livres, em especial glicose e frutose. Durante o período de maturação ocorre a conversão do glicogênio em ácido lático. Essa reação leva á redução do glicogênio, que pode ser observada pela variação do $\mathrm{pH}$ do músculo. Quanto maior a quantidade de glicogênio maiores serão as condições de conservação, devido ao menor pH da carne (PARDI, 1993).

Trindade e Gressoni Júnior (2008), esclarecem que o valor do pH varia de acordo com a espécie e com o músculo, entretanto animais descansados e bem alimentados possuem maiores reservas de glicogênio e portanto alcançam menores valores de $\mathrm{pH}$ no período pós-morte. Além de retardar o crescimento microbiano, o pH ácido é responsável por uma cor mais desejável na carne. Em carne ovina com pH elevado ocorre o aumento da atividade da enzima citocromo oxidase, a qual reduz a captação de oxigênio levando ao predomínio da metamioglobina, e portanto, as carnes adquirem coloração vermelho-amarronzado (OSÓRIO; OSÓRIO; SANUDO, 2009). 
Dentre as substâncias minerais da carne predominam quantitativamente o fósforo e o potássio, seguidos do sódio, do magnésio, cálcio e ferro. Além dessas substâncias, podem ser encontrados nas cinzas da carne vários oligoelementos em baixas concentrações como cobre, manganês, zinco, iodo, flúor, alumínio entre outros (PARDI, 1993).

Os sais minerais contribuem para a manutenção de uma reação quase neutra nos tecidos e líquidos orgânicos, a catalisação em vários processos de grande importância e a reação estimulante exercida sobre a atividade de várias enzimas. Estes elementos são ainda parte integrante de determinados hormônios e de um grande número de enzimas, além de constituir microelementos indispensáveis ao organismo humano e cuja participação está comprovada em determinados processos biológicos (PARDI, 1993).

\subsection{ASPECTOS SENSORIAIS}

Muitos pesquisadores discutem quais os principais fatores de qualidade observados pelos consumidores de carne. Andersen et al. (2005), afirmam que tradicionalmente, os principais atributos são segurança, valor nutricional, sabor, textura, capacidade de retenção de água, cor e estabilidade à oxidação lipídica. De acordo com Osório, Osório e Sañudo (2009), os atributos sensoriais de maior importância na carne ovina são suculência, cor, textura, odor e sabor. Hoffman et al. (2003) afirmam que suculência, dureza e sabor, nessa ordem, são os atributos que definem a aceitabilidade da carne.

Somando-se a isso, devido ás mudanças que ocorreram no mercado da carne nas ultimas décadas, os atributos de qualidade requerem ainda altos padrões relacionados com o ambiente, a ética e o bem estar animal (ANDERSEN et al., 2005). 
A cor é um fator de grande importância e apreciação no momento da compra. A cor vermelha da carne é vista pelos consumidores como indicativo de frescor e saudabilidade (LI et al., 2012). O principal pigmento relacionado com a coloração é a mioglobina, essa proteína está também envolvida nos processos de oxigenação do músculo. Desta forma, animais mais ativos e com maior necessidade de oxigenação do músculo possuem maior teor de mioglobina e, portanto, coloração mais intensa (PARDI, 1993). Outras proteínas como a hemoglobina e o citocromo C também podem ter alguma participação no processo de coloração da carne (MANCINI; HUNT, 2005).

Segundo Ximenes (2010) o fator genético pode influenciar a cor da carne a partir da deposição de pigmentos no tecido muscular ou adiposo. Ainda, segundo este mesmo autor, as concentrações de mioglobina aumentam com o avanço da maturidade fisiológica do animal o que também eleva a intensidade da cor da carne. $\mathrm{O}$ pH também exerce influência sobre a coloração da carne. Fibras musculares com elevado pH final ficam distendidas e criam um obstáculo à absorção da luz e difusão do oxigênio, o que leva á produção de carnes que não brilham e inibição da formação da oximioglobina (SOBRINHO et al., 2005)

Mancini e Hunt (2005) descrevem a mioglobina como uma proteína hidrossolúvel formada por oito $\alpha$-hélices unidas por ligações não helicoidais curtas. A histidina é o principal resíduo dessa proteína e possui papel fundamental na estrutura e função da mioglobina. O ferro do anel heme pode formar seis ligações, quatro dessas ligações são formadas com nitrogênios pirólicos, o quinto sítio forma ligação com a histidina-64 e o sexto está disponível para a formação de ligações reversíveis. De acordo com o ligante presente neste sítio e a valência do ferro podem-se distinguir quatro formas químicas de mioglobina, as quais determinam as quatro possíveis colorações da carne, conforme visto na Figura 1. 
A oximioglobina absorve a luz nas regiões de Soret $(380-440 \mathrm{~nm})$ e entre 480$650 \mathrm{~nm}$. A perda de oxigênio da oximioglobina e um elétron de íon ferroso, produzindo a metamioglobina, são modificações que alteram as propriedades de absorção da molécula e a cor se transforma de vermelho-vivo ao vermelho-escuro e em seguida marrom (KANNER; HAREL; JAFFE, 1994).

Figura 1 - Reações da mioglobina para formação de quatro produtos responsáveis pela coloração da carne.

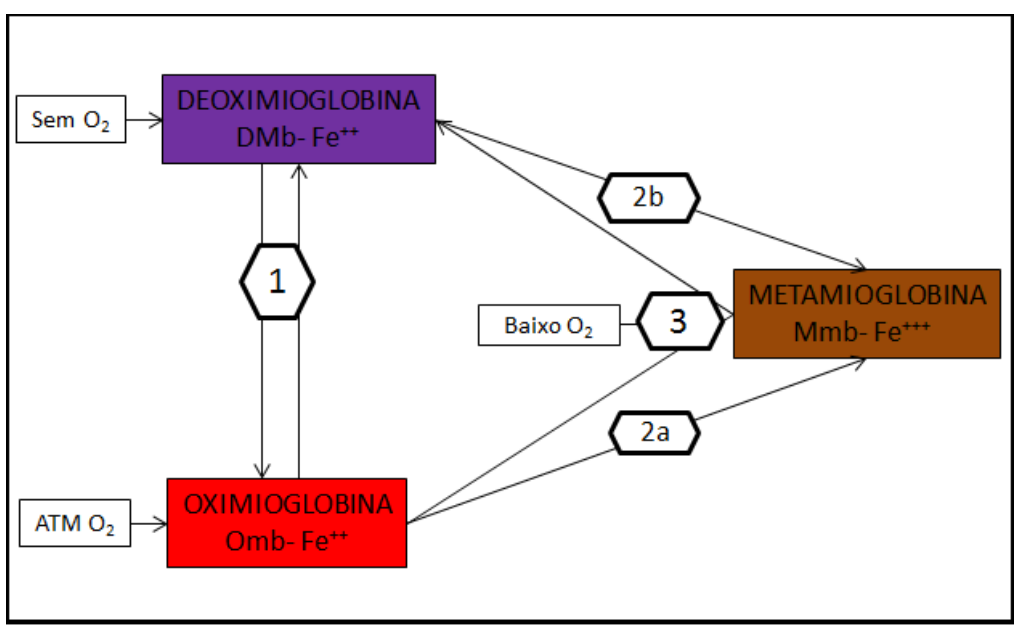

Reação 1- Oxigenação: $\mathrm{DMb}+\mathrm{O}_{2} \rightarrow \mathrm{OMb}$

Reação 2a - Oxidação: $\mathrm{OMb}+$ [consumo de oxigênio ou baixa pressão parcial de $\mathrm{O}_{2}$ ] $-\mathrm{e}^{-} \rightarrow \mathrm{MMb}^{-}$ Reação 2b - Oxidação: [ DMb - íon hidroxil - complexo iônico de hidrogênio ]+ $\mathrm{O}_{2} \rightarrow \mathrm{MMb}+\mathrm{O}_{2}{ }^{-}$ Reação 3 - Redução: $\mathrm{MMb}+$ consumo de oxigênio + atividade redutora da mioglobina $\rightarrow \mathrm{DMb}$ (Fonte: Adaptado de Mancini e Hunt, 2005)

O aparecimento do aroma característico da carne é devido a uma reação de escurecimento não enzimático que ocorre entre os açúcares redutores e os aminoácidos, sendo que glucoproteínas específicas também podem contribuir em parte para a formação do odor. Dentre os principais responsáveis pelo aroma e sabor característico da carne ovina, estão os ácidos graxos de cadeia ramificada. Além disso, compostos voláteis da carne são influenciados por sistemas de alimentação e dietas. Dietas à base de concentrados promovem o aumento da concentração de ácidos graxos de cadeia 
ramificada, enquanto dietas enriquecidas com óleos aumentam o teor de aldeídos. (XIMENES, 2010)

A consistência e a textura da carne são fatores de grande importância durante o consumo. A maciez da carne em especial, tem despertado a atenção de alguns pesquisadores, os quais têm buscado determinar suas causas e fatores de influência (GAGAOUA et al., 2015; LOMIWES et al., 2014; MARINO et al., 2013).

Observa-se que o aumento do peso corporal produz redução significativa na maciez da carne. Isso decorre, principalmente, do aumento do número de ligações químicas termorresistentes entre as moléculas do colágeno. Entretanto, segundo alguns pesquisadores, a dureza de carne de animais abatidos com peso mais elevado não é tão perceptível, devido ao aumento do teor de gordura intramuscular, o que promove um efeito de amaciamento. Nestes casos a análise sensorial é a melhor metodologia a ser empregada para medição da maciez (XIMENES, 2010).

A suculência da carne pode ser percebida de duas maneiras distintas: inicialmente através da umidade, pela rápida liberação de suco, e em seguida, pelo efeito estimulante da gordura sobre o fluxo salivar. Esta última é responsável pela sensação final de secura nas carnes de animais jovens, com baixo teor gordura. A carne de boa qualidade é mais suculenta devido, em parte, ao conteúdo de gordura intramuscular. A quantidade de gordura intramuscular (de infiltração ou marmoreio) é um dos fatores determinantes da suculência. Desta forma, cordeiros jovens podem apresentar carnes menos suculentas devido à baixa deposição deste tipo de gordura (OSÓRIO; OSÓRIO; SANUDO, 2009).

Testes sensoriais realizados com carne ovina demostraram que a deposição e distribuição de gordura influenciam a aceitabilidade da carne. Uma menor quantidade de gordura subcutânea, inter e intramuscular, causou redução significativa na 
aceitabilidade da carne de cordeiros. As carnes magras foram consideradas menos saborosas pelos consumidores. Entretanto, concentrações muito elevadas de lipídeos podem diminuir a apreciação do produto devido aos efeitos negativos que as gorduras saturadas podem proporcionar à saúde humana (SAÑUDO et al., 2000).

Outra desvantagem de carnes com elevado teor lipídio é o desenvolvimento de odores não desejáveis como produtos da oxidação lipídica. Segundo Ladikos e Lougovois (1990) a resistência normal da carne para o desenvolvimento de rancidez depende do equilíbrio entre a presença de antioxidantes nos tecidos animais, o nível de insaturação e a concentração dos ácidos graxos presentes. O antioxidante mais comum em tecido animal é a vitamina $\mathrm{E}$ (tocoferol), que, no entanto, não é de todo disponível para bloquear a oxidação devido à natureza não homogênea do tecido animal. A carne de cordeiro é composta de níveis relativamente elevados $(57,7 \%)$ de ácidos graxos saturados (FORREST et al. 1979) e baixos níveis de tocoferóis naturais. A vitamina E não pode ser sintetizada nos animais, portanto a presença dessa vitamina em tecidos animais reflete a disponibilidade na dieta. Devido às características de lipossolubilidade da vitamina E, a absorção é dependente da habilidade dos animais digerirem e absorverem gordura. Em geral, cordeiros recebem alimentação suplementada com vitamina E (SILVA et al., 2011).

As características de cor, textura, consistência, suculência e maciez da carne cozida dependem, em parte, da capacidade de retenção de água (CRA). O interesse em estudar a capacidade de retenção de água (CRA) pelo músculo, além de sua importância tecnológica, está relacionado com a influência que este parâmetro exerce nas características sensoriais da carne antes e após o cozimento, e sua participação na palatabilidade do produto (PARDI, 1993). Define-se CRA como a capacidade da carne reter sua própria água durante a aplicação de forças externas, tais como cortes, 
aquecimento, trituração e prensagem (XIMENES, 2010). Baixos níveis de CRA podem promover consideráveis perdas de umidade e, consequentemente de peso na carcaça, levando á redução do lucro de venda e perdas na textura. Entretanto, uma CRA adequada, juntamente com um bom nível de gordura intramuscular, pode favorecer uma maior suculência na carne.

De acordo com pesquisas relatadas por Ximenes (2010) a idade do animal tem efeito na CRA, o que em parte é devido ao aumento da gordura subcutânea e intermuscular. Outro fator de influência é o genótipo, por exemplo, cordeiros da raça Lacha possuem valores de CRA superiores aos da raça Aragonesa. Segundo Pardi (1993) o pH elevado, a glicólise pós-morte lenta, o resfriamento rápido da carcaça antes da instalação do rigor mortis e a armazenagem a temperaturas próximas a $0^{\circ} \mathrm{C}$ aumentam a CRA. Ainda segundo ele, todos os fatores que afetam a capacidade de retenção de água da carne afetam também a capacidade de retenção de água congelada e descongelada.

Os conhecimentos relacionados com a CRA são importantes para o entendimento dos fenômenos físicos que ocorrem na carne, por exemplo, as perdas de peso, textura e suculência nos diversos cortes e no armazenamento. Assim é possível criar estratégias de proteção contra tais perdas.

\subsection{FATORES DE DETERIORAÇÃO}

A carne é considerada um excelente meio de cultura para os microrganismos, pois apresenta diversas características que favorecem seu crescimento, como alta atividade de água, $\mathrm{pH}$ favorável para a maioria dos microrganismos, elevado teor de nutrientes e ausência de constituintes antimicrobianos (FRANCO; LANDGRAF, 2008). 
A contaminação da carne e produtos cárneos ocorre durante a manipulação e o processamento do produto. Por isso, a quantidade e os tipos de microrganismos que se desenvolvem nesses alimentos dependem dos fatores ante e post mortem como: alimentação, genética, idade, condições de abate, resfriamento após o abate, maturação e métodos de cocção (ALCANTARA; MORAIS, SOUZA, 2012).

Devido ao pH mais alto da carne, a deterioração geralmente é provocada pelo desenvolvimento de bactérias proteolíticas. O grupo de psicrotróficos inclui bactérias Gram negativas, não esporuladas e sensíveis ao calor. Os gêneros mais encontrados são Aeromonas, Alcaligenes, Cytophaga, Flavobacterium, Pseudomonas, Serratia e Vibrio. Algumas bactérias são Gram positivas como Arthrobacter, Bacillus, Clostridium e Micrococcus. Dentre estas, várias são responsáveis pela deterioração do produto e consequente diminuição da validade comercial (ALCANTARA; MORAIS, SOUZA, 2012).

Os diversos fatores que influenciam a deterioração de produtos cárneos por microrganismos relacionam-se com a atmosfera gasosa que os envolve. Assim tem-se deterioração provocada por microrganismos aeróbios e anaeróbios (ALCANTARA; MORAIS, SOUZA, 2012). .

Dentre as alterações causadas por microrganismos aeróbicos tem-se a limosidade superficial, alteração na cor dos pigmentos da carne, rancificação, fosforescência, alterações na cor e odores e sabores estranhos. A deterioração anaeróbia ocorre no interior da carne, em produtos embalados a vácuo ou em embalagens fechadas onde o oxigênio é ausente ou limitado. Um grupo de bactérias psicrotróficas de grande importância em carnes e produtos cárneos são as bactérias ácido lácticas. O crescimento a níveis elevados destas bactérias pode provocar mudanças sensoriais, como odores ácidos indesejáveis (ALCANTARA; MORAIS, SOUZA et al., 2012). 
Dentre os fatores de deterioração de origem não microbiana, a rancidez oxidativa e a alteração de cor são os mais perceptíveis. A oxidação lipídica com formação de odores indesejáveis é considerada uma das principais causas de perda de qualidade e rejeição pelo consumidor em carnes e produtos cárneos em geral (GRAY, GOMA E BUCKLEY, 1996). A composição da gordura, exposição à luz e O 2 , grau de dispersão dos lipídeos, atividade de água (Aa) e presença de agentes pró e antioxidantes também exercem influência sobre este parâmetro de qualidade (ORDÓNEZ et al., 2005).

A rancidez oxidativa é proveniente da oxidação dos ácidos graxos poliinsaturados presentes na carne. A carne ovina possui maior quantidade de ácidos graxos saturados, quando comparada com carnes de aves e/ou suínos, que apresentam maior quantidade de ácidos graxos insaturados; sendo assim, ela é menos susceptível a este tipo de rancidez (MONTEIRO; RÜBENSAM; PIRES, 2001).

De acordo com Mancini e Hunt (2005) a formação de oximioglobina e deoximioglobina, além de ter papel na formação da cor da carne, também pode ter participação na oxidação lipídica. Quando a oximioglobina é formada, a interação entre histidina e oxigênio diatômico puxa o ferro mais para dentro do plano do anel heme, ao contrário do que acontece quando a deoximioglobina se forma, onde a falta da interação oxigênio-histidina faz com que o ferro seja deslocado para fora do plano. Todas essas alterações levam a existência de dois tipos de estruturas terciárias das moléculas de proteína, uma mais aberta, quando a deoximioglobina é formada e outra mais fechada, na ocorrência da oximioglobina. A maior abertura da molécula de deoximioglobina favorece o acesso de oxidantes à molécula, e consequentemente possibilita a oxidação (MANCINI; HUNT, 2005). 
De acordo com Calnan et al. (2014), na Austrália o fator limitante para a validade comercial de carne de cordeiro em retalho é a coloração, que faz com que este produto tenha um tempo de vida de prateleira de apenas dois dias. Brooks et al. (2012), afirmam que o consumo de carnes comercializadas em varejo é historicamente ligado à sua aparência. Fatores como a descoloração, ou aparecimento de metabioglobina, podem discriminar ou causar a rejeição do produto em níveis de 30 a $40 \%$.

Diversos fatores podem causar alterações na coloração da carne. De acordo com Rosenvold e Wiklund (2011), lombos (Longissimus dorsi) de cordeiros armazenados em diferentes temperaturas em atmosferas com $80 \% \quad \mathrm{O}_{2}$ se tornaram menos luminosos, menos vermelhos e menos amarelos com o aumento do período de estocagem. Jacob et al. (2014) afirmam que a relação oximioglobina/metamioglomina diminuiu ao longo do tempo para o músculo Longissimus thoracis et lumborum de cordeiros. Além disso, esse mesmo estudo comprovou que há diferença significativa na velocidade de redução da relação oximioglobina/metamioglobina entre as raças e em diferentes valores de $\mathrm{pH}$. De acordo com Singh et al. (2011) a taxa de formação da metamioglobina aumenta de acordo com o aumento da temperatura de estocagem para todos os tipos de músculos.

Kim et al. (2012), demonstraram que o tipo de embalagem também possui grande influência na coloração de lombos (Longissimus dorsi) de cordeiro; amostras embaladas em sistemas com elevado teor de oxigênio (80\%) possuíram valores de L* significativamente maiores que as amostras embaladas em PVC; Estas amostras também apresentaram valores de $a^{*}$ mais elevados no primeiro dia de armazenamento, mas a taxa de descoloração foi mais rápida para essas amostras do que para as embaladas em PVC. Os autores explicaram a redução do teor de vermelho como causado pela oxidação da mioglobina quando exposta a altas concentrações de oxigênio. 
Lagerstedt, Lundström, Lindahl (2011), explicaram que embalagens com alto teor de oxigênio reduzem a vida de prateleira da carne em comparação com embalagens a vácuo, pois a presença de $\mathrm{O}_{2}$ produz off-flavors e permite o crescimento de bactérias aeróbias. No entanto, a cor púrpura da desoximioglobina da carne em embalagem a vácuo e a perda de água visível no saco de vácuo são consideradas não atraentes para os consumidores, razões pelas quaais a embalagem a vácuo não é frequentemente usada para exibição em varejo.

\subsection{SÓDIO EM ALIMENTOS}

Quando a Organização Mundial da Saúde (2006) recomendou a redução dos níveis diários de ingestão de sódio, a redução de sal em alimentos se tornou uma área de grande interesse para os pesquisadores. Entretanto, a função do sódio em produtos alimentícios vai além de aspectos sensoriais, afetando aspectos tecnológicos e de segurança alimentar (GROSSI, 2012).

No organismo humano, o sódio está envolvido nos processos de manutenção do fluxo de fluidos intra e extracelulares, sendo assim ele possui papel essencial na regulação e manutenção da pressão sanguínea. Porém, a ingestão deste composto deve ser limitada a $1,7 \mathrm{~g} / \mathrm{dia}$ por pessoa (aproximadamente $5 \mathrm{~g}$ de cloreto de sódio). $\mathrm{O}$ consumo excessivo, maior que $6 \mathrm{~g}$ diários de $\mathrm{NaCl}$, é uma importante causa de hipertensão arterial (BRASIL, 2004). Horita et al. (2014) reportam que os produtos cárneos são responsáveis por 20 a 30\% do total diário de ingestão de sódio.

No alimento, o sal tem influência nas ligações de água e gordura, textura e perdas pelo cozimento (RUUSUNEM et al., 2005). Além disso, a presença de sódio não garante apenas a percepção do gosto salgado, ele é responsável por acentuar o sabor dos produtos cárneos de modo geral. Karki et al. (2005), concordam que as funções mais importantes do sódio no processamento de produtos cárneos são: emulsificação, 
extração de proteínas, retenção de água, ligação de gordura, ação bacteriostática, melhoria da cor, favorecimento de rendimento e textura mais aceitáveis, melhor sabor e maior vida de prateleira. A melhoria na capacidade de retenção de água contribui para a formação de estruturas de gel mais estáveis. Já a redução da atividade de água desfavorece o crescimento microbiano (PIETRASIK; GAUDETTE, 2014).

Segundo Goli et al. (2014), quando usado em pequenas quantidades, o sal melhora a capacidade de retenção de água da carne crua e cozida, pois o ânion cloreto possui efeito hidratante em virtude de sua forte afinidade com o grupo catiônico das proteínas $\left(\mathrm{R}_{-} \mathrm{NH}_{3}{ }^{+}\right)$, o que diminui a atração eletrostática entre proteínas, que estão bem mais fortes no $\mathrm{pH}$ inicial da carne, próximo ao $\mathrm{pH}$ isoelétrico.

\subsection{ESTRATÉGIAS DE CONSERVAÇÃO DE CARNES E PRODUTOS CÁRNEOS}

\subsubsection{Embalagens em atmosfera modificada}

A embalagem é sistema de preparação de bens para o transporte, distribuição, armazenamento, venda e consumo final. Ela possui além da função de proteção passiva (constitui uma barreira à contaminação e choques físicos) e ativa (criando ambientes protetores - anaerobiose, vácuo e atmosfera modificada), funções de conservação, de informação sobre o produto e marketing (FREITAS; FIGUEIREDO, 2000).

A tecnologia de acondicionamento em Atmosfera Modificada (ATM) é um sistema que tem se destacado. Ela consiste na substituição do ar, no espaço livre da embalagem, por uma mistura de gases de composição pré-determinada. O aumento do prazo comercial resultante da aplicação deste método de conservação dá-se, entre outras razões, pelo efeito inibitório do gás carbônico sobre os diferentes tipos microbianos (MANTILLA et al., 2010), quando este gás é empregado na composição gasosa. No 
entanto, a combinação ideal entre os gases tal que preserve a cor da carne fresca e mantenha o controle do crescimento de microrganismos ainda é um grande desafio. Venturini et al (2006), Maqsood e Benjakul (2010), Lagerstedt; Lundström e Lindahl (2011), Linares e Vergara (2012), Murphy, O'Grady e Kerry (2013) e Fernandes et al. (2014) são alguns dos pesquisadores que têm estudado a aplicação da embalagem em atmosfera modificada em carnes e produtos cárneos.

Durante a estocagem, muitos produtos estão sujeitos à perda de qualidade decorrente das reações que ocorrem entre seus componentes e os gases que o circundam. O oxigênio é um dos principais responsáveis por essa perda de qualidade. Além da oxidação lipídica, o oxigênio pode provocar oxidação de pigmentos, aromas e vitaminas, alterando as características organolépticas e o valor nutricional dos alimentos. Assim, a deterioração da qualidade da carne pode incluir a perda da cor vermelha, crescimento microbiano, desenvolvimento de aroma e odor desagradáveis e desidratação superficial (SARANTÓPOULOS, 2002).

Os processos utilizados na preservação da carne estão relacionados principalmente com a inibição da contaminação microbiana, entretanto esse cuidado deve vir acompanhado de estratégias que minimizem a depreciação da qualidade do produto (LOWRIE, 2005).

Durante o armazenamento a composição gasosa do interior da embalagem tende a entrar em equilíbrio com a composição do exterior o que ocorrerá em maior ou menor velocidade a depender das características de permeabilidade do material da embalagem. As mudanças na composição da atmosfera da embalagem podem ter origem microbiológica, bioquímica, química e/ou ser resultante da interação da embalagem com o produto e/ou com o ambiente externo (SARANTÓPOULOS, 2002). 
$\mathrm{O}_{2}, \mathrm{~N}_{2}$ e $\mathrm{CO}_{2}$, são os três gases mais utilizados nas embalagens em atmosfera modificada (SINGH et al, 2011). A escolha da concentração de cada gás na mistura é determinada por diversos fatores, como os tipos de microrganismos que são capazes de se desenvolver no produto, a sensibilidade do produto ao $\mathrm{O}_{2}$ e ao $\mathrm{CO}_{2}$ e da estabilidade da cor desejada. $\mathrm{O} \mathrm{CO}_{2}$ é reconhecido pela sua ação bacteriostática, logo, o efeito inibitório da ATM no desenvolvimento de microrganismos é diretamente relacionado com a quantidade de $\mathrm{CO}_{2}$ presente. Elevadas concentrações de gás carbônico permitem o crescimento de microrganismos anaeróbios facultativos, como as bactérias ácido láticas, porém em velocidade lenta, atrasando a deterioração da carne. O nitrogênio é um gás quimicamente inerte usado como um gás de enchimento para substituir o $\mathrm{O}_{2}$, retardando, a rancificação oxidativa e inibindo o crescimento de microrganismos aeróbios (MANTILLA et al., 2010).

Segundo estudos citados por Lonergan et al.. (2010), embalagem em atmosfera modificada, geralmente sistemas com $80 \%$ de oxigênio $\left(\mathrm{O}_{2}\right)$ e $20 \%$ de dióxido de carbono $\left(\mathrm{CO}_{2}\right)$, são amplamente utilizados no mercados de carne, pois o $\mathrm{O}_{2}$ favorece o desenvolvimento da cor vermelha brilhante, que é atraente para os consumidores. Além disso, o $\mathrm{CO}_{2}$ auxilia na prevenção do crescimento microbiano. Entretanto, altos níveis de $\mathrm{O}_{2}$ promovem alterações oxidativas na carne, afetando negativamente sua qualidade, incluindo a estabilidade da cor, sabor e maciez. Um elevado nível de $\mathrm{O}_{2}$ pode induzir ligações cruzadas entre moléculas de proteínas o que diminui, posteriormente, a maciez e a suculência da carne. A presença de oxigênio também aumenta a velocidade de oxidação dos lipídios, o que provoca alterações indesejáveis na cor e sabor (ESMER et al., 2011).

Segundo Lonergan (2010), músculos bovinos armazenados em embalagens com alto teor de oxigênio tiveram altos valores de oxidação lipídica, de acordo com o teste 
de determinação da quantidade de substâncias reativas ao ácido tiobarbitúrico (TBARS). Foi verificado também que a intensidade da descoloração da carne variou para os grupos de músculos estudados, o que pode indicar que as diferentes atividades fisiológicas do músculo influenciem a estabilidade à oxidação da mioglobina.

Sheridan et al. (1997), estudando peças desossadas de cordeiro por 28 dias, verificaram que os tratamentos contendo $80 \% \mathrm{O}_{2}+20 \% \mathrm{CO}_{2}, 50 \% \mathrm{~N}_{2}+50 \% \mathrm{CO}_{2} \mathrm{e}$ $100 \% \mathrm{CO}_{2}$ tiveram uma contagem menor de enterobactérias em relação às carnes que foram embaladas à vácuo. Todos os tratamentos foram submetidos às temperaturas de 0 e $5^{\circ} \mathrm{C}$, sendo que em temperatura de $5^{\circ} \mathrm{C}$, a contagem microbiana foi maior em embalagens à vácuo e com $50 \% \mathrm{~N}_{2}+50 \% \mathrm{CO}_{2}$. Além disso, a produção de odores foi significativamente maior em temperaturas à $5^{\circ} \mathrm{C}$ se comparada com $0^{\circ} \mathrm{C}$, com exceção do tratamento contendo $100 \% \mathrm{CO}_{2}$.

Após análises do músculo longissimus dorsi de ovinos, Kennedy, Buckley e Kerry (2004), concluíram que altas concentrações de $\mathrm{O}_{2}$ em relação ao teor de $\mathrm{CO}_{2}$, utilizados em uma mesma atmosfera, garantem um maior tempo de manutenção da cor vermelha da carne. Em estudos realizados com o músculo Longissimus dorsi de ovinos acondicionados em diferentes concentrações de $\mathrm{CO}_{2}$, Vergara e Gallego (2001), concluíram que níveis maiores de $40 \%$ deste gás mantêm a carne livre de odores estranhos.

\subsubsection{Marinação}

Para ser rotulado como marinado, o produto deve usar a marinada, que é uma mistura na qual o alimento é imerso, massageado ou injetado, a fim de melhorar o sabor, a textura, ou outros atributos sensoriais, como por exemplo, a cor ou suculência (USDA, 2005). Em geral, sal e ácido são ingredientes essenciais para a marinada e 
proporcionam as características desejadas citadas. Além disso, segundo Pathania et al. (2010) a crescente demanda por produtos de conveniência e com maior vida de prateleira, tem aumentado o interesse no uso de especiarias, sais e ácidos orgânicos em marinadas, com a finalidade de aumentar a segurança do alimento.

Quando feita pelo consumidor, a marinação geralmente é realizada por imersão. Neste processo, a carne é imersa em um líquido que penetra na carne através da difusão ao longo do tempo. As marinadas comerciais geralmente são emulsões de óleo em água contendo também especiarias, sal e açúcar, além de aditivos funcionais (gomas) e agentes antimicrobianos (sorbato ou benzoato) (YUSOP et al., 2010). O benefício para os consumidores da compra da carne já marinada é a facilidade de preparo, visto que o cozimento é a única etapa necessária no preparo deste tipo de alimento (NIEMINEN et al., 2012)

A marinação em meios fracamente ácidos é uma maneira de dar mais sabor e maciez à carne. Yusop et al. (2012) explicam que a incorporação de ácidos orgânicos na marinada tem como principal objetivo aumentar o sabor e a maciez, e não atuar como adjuntos de preservação. Entretanto, Toomik et al., (2012), mostraram que os ácidos cítrico e ascórbico foram capazes de suprimir significativamente a oxidação em carne de porco marinada.

Sharedeh et al. (2015) concordam que além de aumentar o sabor e melhorar a textura, a utilização da marinada também pode afetar a cor e os aspectos sensoriais da carne. Os autores esclarecem que o inchamento da fibra antes do cozimento causado pela diminuição do pH é a causa da maior maciez da carne cozida.

De acordo com Goli et al. (2014), após a imersão da carne na marinada, o sal e o ácido penetram nos tecidos provocando a queda do $\mathrm{pH}$ e a consequente hidratação das proteínas. Gault (1985) explica que a hidratação das moléculas é mantida após o 
cozimento o que também contribui para o aumento da maciez. Vários mecanismos estão envolvidos no processo de aumento da maciez e aumento da capacidade de retenção de água da carne, dentre eles pode-se citar a queda do pH, o aumento da força iônica, ação enzimática e diminuição da força eletrostática entre as cadeias de proteínas (GOLI et al., 2014; HWANG; LIN; CHOU, 2000).

Goli et al publicaram uma série de pesquisas envolvendo o comportamento de músculos quando submetidos a diferentes condições de pH (GOLI et al, 2011, 2012, 2014). Eles observaram que nos primeiros 5 minutos após a imersão de cubos de peito de peru na solução de marinação, houve uma queda no valor de $\mathrm{pH}$ de até uma unidade. De acordo com os autores a rápida queda inicial é devida à perda da capacidade tamponante da carne. Esse comportamento foi observado em marinadas com e sem sal em sua composição. Os autores também observaram que quando a carne é marinada em um meio água-ácido é possível observar uma alta porcentagem de ganho de massa. Essa porcentagem é maior do que a observada em carnes marinadas com ácido e sal. O inchamento das fibras musculares observado nas carnes submetidas à marinação em meio água-ácido é explicado pelos pesquisadores como resultado da repulsão eletrostática e enfraquecimento da estrutura das proteínas. Quando a marinada contém sal, a concentração de 0,2 a $0,3 \mathrm{M}$ de sal é limitante para que a hidratação do musculo ocorra. Valores superiores que estes causaram perda de massa.

Algumas especiarias também são comumente utilizadas na preparação da marinada. Algumas dessas especiarias são conhecidas pelo seu poder antimicrobiano. A cebola, o alho, o orégano e a pimenta preta, possuem alguns constituintes que possuem ação efetiva contra bactérias gram positivas e gram negativas (BENKEBLIA, 2004; TAJKARIMI; IBRAHIM; CLIVER, 2010; ZARAI et al., 2013). 
O cloreto de sódio também é um ingrediente comum na marinada. Em produtos cárneos, o sal é essencial devido aos seus efeitos em propriedades como capacidade de retenção de água, ligação de gordura, cor, redução da atividade de água com consequente efeito bacteriostático, sabor e textura (BAK et al., 2012; DURANTON et al., 2012). No entanto, a relação do cloreto de sódio com o desenvolvimento da hipertensão e doenças coronarianas, tem levado pesquisadores a buscar novos ingredientes ou processos que possibilitem a redução desse composto em alimentos.

\subsubsection{Alta Pressão}

O uso de alta pressão em produtos cárneos é uma tecnologia promissora que tem despertado o interesse de alguns pesquisadores, principalmente devido ao apelo dos consumidores por alimentos seguros e minimamente processados. Esta tecnologia tem sido utilizada em conjunto com outros métodos de conservação de alimentos, tais como a utilização de sal (CREHAN, TROY E BUCKLEY, 2000; DURANTON et al., 2012; O'Flynn et al., 2014).

De acordo com Torrezan (2003), o processamento em alta pressão (high pressure processing - HPP) é uma alternativa para garantir a segurança de produtos cárneos após o processamento, e, por ser um tratamento mais brando, quando comparado com tratamentos que empregam altas temperaturas, ele permite a obtenção de produtos com maior qualidade sensorial e nutricional, sem que haja prejuízo na redução da carga microbiana.

Pressões na faixa de 100 a 800 Mpa podem ser aplicadas em produtos cárneos e pressões superiores a $300 \mathrm{MPa}$ ajudam a inativar microrganismos, fazendo com que o produto seja microbiologicamente mais seguro (BAK et al., 2012). Além disso, o processamento a alta pressão não altera marcadamente o gosto, sabor ou o conteúdo de 
nutrientes dos alimentos, e pode ser realizado em temperatura ambiente (CREHAN, TROY, BUCKLEY, 2000).

Uma vantagem na utilização do HPP é que sua aplicação tem mostrado modo de ação em proteínas miofibrilares semelhante aos sais, de modo que o teor de cloreto de sódio pode ser reduzido em produtos cárneos tratados com o processamento a alta pressão sem que haja grandes alterações no produto (OMANA; PLASTOW; BETTI, 2011).

Duranton et al. (2012) investigaram a interação de alta pressão (até $500 \mathrm{MPa}$, a $20{ }^{\circ} \mathrm{C}$ durante $\left.6 \mathrm{~min}\right)$ com cloreto de sódio $(0 \%$-3\%) ou nitrito de sódio ( 0 mg / kg-100 mg / kg) sobre o crescimento de quatro grupos de bactérias endógenas (bactérias aeróbios mesófilos, bactérias mesófilas anaeróbias, bactérias ácido lácticas, e enterobactérias) de carne suína durante o armazenamento depois de uma pausa de cadeia de frio. Na opinião deles, a utilização do tratamento de alta pressão pode ser uma abordagem para limitar a adição de nitrito e sódio no produto e garantir, ao mesmo tempo, a extensão da vida de prateleira do produto. O'Flynn et al. (2014) investigaram os efeitos da alta pressão (0 ou $150 \mathrm{MPa}$ ) no tratamento de carne suína antes de fabricar salsichas com níveis de sal reduzidos $(0,5,1,0,1,5,2,0$ e 2,5\%). Eles concluíram que o tratamento HPP aumentou a estabilidade da emulsão e reduziu a perda de peso por cozimento (CL) em relação ao tratamento controle; a redução de sal abaixo de $1,5 \%$ prejudicou atributos sensoriais, de cor e de textura. Crehan, Troy e Buckley (2000), investigaram os efeitos do nível de sal $(1,5$ e 2,5\%) e de processamento de alta pressão (150 e $300 \mathrm{MPa}$ ) sobre a perda no cozimento, a estabilidade da emulsão, cor, textura e características sensoriais de salsichas. O estudo sugere que o nível de sal pode ser reduzido para $1,5 \%$ sem qualquer mudança significativa na perda por cozimento, e a estabilidade da emulsão das salsichas pode ser melhorada com a redução do sal, 
independente do nível de pressão aplicada. Muitas das características sensoriais foram melhoradas quando o teor de sal dos produtos foi reduzido para $1,5 \%$.

O processamento em alta pressão pode afetar a estabilidade de lipídeos. De acordo com Omana, Plastow e Betti (2011), a alta pressão leva a catálise da oxidação desses compostos. Andres et al. (2004) confirmou que HPP promove a oxidação lipídica e induz mudanças de cor no presunto curado em fatias. A estabilidade dos lipídeos é de importância crucial para os alimentos semi-prontos, tais como carne marinada, que estão se tornando cada vez mais populares (TOOMIK et al., 2012).

Muitos investigadores relataram o efeito de altas pressões em microrganismos em produtos cárneos, a maioria deles em presunto e carne de aves (GARRIGA et al., 2004; LERASLE et al., 2014; MYERS et al., 2013; YUSTE et al., 1999). Salmonela enterica e Listeria monocytogens são as bactérias mais comuns em seus estudos, provavelmente devido ao grande envolvimento destes microrganismos em doenças transmitidas por alimentos. De acordo com Lerasle et al. (2014), L. monocytogenes é uma das maiores causadoras de doenças transmitidas por alimentos em humanos e pode sobreviver e crescer durante o armazenamento refrigerado sob embalagem de atmosfera modificada. Rhoads et al. (2013) afirmam que, aproximadamente, 1,3\% de carcaças de carne bovina resfriada e $3,8 \%$ de carne crua foram encontrados contaminados com Salmonela. 


\section{REFERÊNCIAS}

ABIEC. Exportações Brasileiras de Carne bovina. 2015. Disponível em < http://www.abiec.com.br/download/jan-out2015.pdf> Acesso em 10 dez. 2015.

ALCANTARA, M.; MORAIS, I. C. L.; SOUZA, C. M. O. C.C. Principais

Microrganismos envolvidos na deterioração das características sensoriais de derivados cárneos. Revista Brasileira Higiene Sanidade Animal. Fortaleza, v. 6, n. 11, p. 1-18, 2012.

ANDERSEN, H.J. et al. Feeding and meat quality - a future approach. Meat Science, Amsterdam, v.70, p. 543-554, 2005.

BAK, K.H. et al. High pressure effect on the color of minced cured restructured ham at different levels of drying, pH, and NaCl. Meat Science, Amsterdam, v. 90, p. 690-696, 2012 .

BENKEBLIA, N. Antimicrobial activity of essential oil extracts of various onions (Allium cepa) and garlic (Allium sativum). LWT- Food Science and Technology, Londres, v.37, p. 263-268, 2004.

BRASIL. Ministério da Agricultura. Exportação. Disponível em < http://www.agricultura.gov.br/animal/exportacao> Acesso em 10 dez. 2015.

BROOKS, J. C., et al . Shelf life and stability traits of traditionally and modified atmosphere packaged ground beef patties treated with lactic acid bacteria, rosemary oleoresin, or both prior to retail display. Meat Science, Amsterdam, v. 90, p. 20-27, 2012.

CALNAN, H.B. et al. Factors affecting the colour of lamb meat from the longissimus muscle during display: The influence of muscle weight and muscle oxidative capacity. Meat Science, Amsterdam, v.96, p. 1046-1057, 2014.

CAVALCANTI, M.R. Mercado mundial da carne bovina: perspectivas para o Brasil. Beefpoint. 2015. Disponível em < http://www.beefpoint.com.br/cadeiaprodutiva/editorial/mercado-mundial-da-carne-bovina-perspectivas-para-o-brasil-49274/> Acesso em 10 dez. 2015.

CHAMORRO, A. Innovations and trends in meat consumption: An application of the Delphi method in Spain. Meat Science, Amsterdam, v. 92, p. 816-822, 2012.

CORRÊA, R. Proovinos 2012: Brasil pode deixar de produzir 13 mil t de carne ovina. Rural Centro. Ed. Pecuária, 2012. Disponível em

<http://www.ruralcentro.com.br/noticias/58144/proovinos-2012-brasil-pode-deixar-de-produzir13-mil-t-de-carne-ovina $>$ Acesso em 12 set.2012.

CREHAN, C.M.; TROY, D.J. ; BUCKLEY, D.J. Efects of salt level and high hydrostatic pressure processing on frankfurters formulated with 1.5 and $2.5 \%$ salt. Meat Science, Amsterdam, v. 55 p. 123-130, 2000. 
DURANTON, F. et al. Combined use of high pressure and salt or sodium nitrite to control the growth of endogenous microflora in raw pork meat. Innovative Food Science and Emerging Technologies, Amsterdam, v. 16, p. 373-380, 2012.

DÍAZ, M.T. Use of concentrate or pasture for fattening lambs its effecton carcass and meat quality. Small Ruminat Research, Milton Keynes, v.43, p. 267-258, 2002.

ESMER, O. K.; IRKIN, R.; DEGIRMENCIOGLU, N.; DEGIRMENCIOGLU, A. The effects of modified atmosphere gas composition on microbiological criteria, colour and oxidation values of minced beef meat. Meat Science, Amsterdam, v. 88, p.221-226, 2011.

FDA. Guidance for Industry: A Food Labeling Guide 9- Appendix A: Definitions of Nutrient Content Claims. 2013. Available in < http://www.fda.gov/Food/GuidanceRegulation/GuidanceDocumentsRegulatoryInformat ion/LabelingNutrition/ucm064911.htm> Acesso em 20 set.2015.

FIRETTI, R. et al. Percepção de consumidores paulistas em relação à carne ovina: análise fatorial por componentes principais. Revista Brasileira de Saúde na Produção Animal, Salvador, v.11, n.1, p 1-13, jan/mar, 2010.

FRANCO, B. D. G. M.; LANDGRAF, M. Microbiologia dos alimentos. São Paulo: Editora Atheneu, 2008. 93-98 p.

FREITAS, A. C.; FIGUEIREDO, P. Conservação de Alimentos. Lisboa, 2000.

Disponível em <http://www.pfigueiredo.org/Book.pdf> Acesso em 16 set.2012.

FORREST, J.C. et al. Fundamentos de ciencia de la carne. Zaragoza: Acribia, 1979. $363 p$.

GAGAOUA, M. et.al. Coherent correlation networks among protein biomarkers of beef tenderness: What they reveal. Journal of Proteomics, Amsterdam, v. 128, p. 365-374, 2015.

GAULT, N. F. S. The relationship between water-holding capacity and cooked meat tenderness in some beef muscles as influenced by acidic conditions below the ultimate ph. Meat Science, Amsterdam, v. 15, ed.1, p. 15-30, 1985.

GRAY, J. I.; GOMA, E. A.; BUCKLEY, D. J. Oxidative quality and shelf life of meats. Meat Science, Amsterdam, v.43, p. 111-123, 1996.

GARRIGA, M. et al. Microbial inactivation after high-pressure processing at $600 \mathrm{MPa}$ in commercial meat products over its shelf life. Innovative Food Science and Emerging Technologies, Amsterdam, v. 5, p. 451-457, 2014.

GOLI, T. et al. Mass transfer dynamics during the acidic marination of turkey meat. Journal of Food Engineering, London, v. 104, ed. 1, p. 161-168, 2011.

GOLI, T. et al. Evolution of ph during immersion of meat protein matrices in acidic marinades. Meat Science, Amsterdam , v. 90, ed. 3, p. 618-623, 2012. 
GOLI, T. et al. Influence of sodium chloride and $\mathrm{pH}$ during acidic marination on water retention and mechanical properties of turkey breast meat. Meat Science, Amsterdam, v. 96, p. 1133-1140, 2014.

GROSSI, A. at al. Reduction of salt in pork sausages by the addition of carrot fibre or potato starch and high pressure treatment. Meat Science, Amsterdam, v. 92, p.481489, 2012.

GROSSI, A. et al. High pressure treatment of brine enhanced pork semitendinosus: Effect on microbial stability, drip loss, lipid and protein oxidation, and sensory properties. Innovative Food Science and Emerging Technologies, Amsterdam, v. 22, p. 11-21, 2014.

HECHION, M. et al. Meat consumption: Trends and quality matters. Meat Science, Amsterdam, v. 98, p.561-568, 2014.

HOFFMAN, L.C. et al. Comparison of six crossbred lamb types: sensory, physical and nutritional meat quality characteristics. Meat Science, Amsterdam, v. 65, p. 1265-1274, 2003.

HOPKINS, D.L.; FOGARTY, N.M.; MORTIMER, S.I. Genetic related effects on sheep meat quality. Small Ruminant Research, Milton Keynes, v. 101, p. 160-172, 2011.

HORITA, C.N., et al. Textural, microstructural and sensory properties of reduced sodium frankfurter sausages containing mechanically deboned poultry meat and blends of chloride salts. Food Research International, Kidlington, v. 66, p. 29-35, 2014.

HORSFIELD, S.; TAYLOR, L. J. Exploring the relationship between sensory data and acceptability of meat. Journal of the Science of Food and Agriculture, Chichester, v. 27, p.1044-1056, 1976.

HWANG, I. H., LIN, C. W.; CHOU, R. G. R. Effect of lactic or acetic acid on degradation of myofibrillar proteins in post-mortem goose (anser anser) breast muscle. Journal of the Science of Food and Agriculture, Chichester, v. 80(2), p. 231-236, 2000.

JACOB, R.H. et al. Phenotypic characterisation of colour stability of lamb meat. Meat Science, Amsterdam, v. 96, p. 1040-1048, 2014.

KANNER, J., HAREL, S.; JAFFE, R. Oxidative Processes in Meat and Meat Products: Quality Implications. Meat Science, Amsterdam, v. 36, p. 169-189, 1994.

KENNEDY, C.; BUCKLEY, D.J.; KERRY, J.P. Display life of sheep meats retail packaged under atmospheres of various volumes and compositions. Meat Science, Amsterdam, v. 68, p. 649-658, 2004.

KIM, Y.H.B. et al. Effect of lamb age and retail packaging types on the quality of longterm chilled lamb loins. Meat Science, Amsterdam, v. 90, p. 962-966, 2012. 
LADIKOS, D.; LOUGOVOIS, V. Lipid Oxidation in Muscle Foods: A Review. Food Chemistry, Amsterdam, v. 35, p. 295-314, 1990.

LAGERSTEDT, Å., LUNDSTRÖM, K. \& LINDAHL, G. 2011. Influence of vacuum or high-oxygen modified atmosphere packaging on quality of beef $M$. longissimus dorsi steaks after different ageing times. Meat Science, 87, 101-106.

LAWRIE, R. A. Ciência da carne. 6.ed. Porto Alegre: Artmed, 2005.

LEÃO, A. G. et al. Características nutricionais da carne de cordeiros terminados com dietas contendo cana-de-açúcar ou silagem de milho e dois níveis de concentrado.

Revista Brasileira de Zootecnia, Viçosa, v.40, n.5, p.1072-1079, 2011.

LERASLE, M. et al. Assessment of Salmonella and Listeria monocytogenes level in ready-to-cook poultry meat: Effect of various high pressure treatments and potassium lactate concentrations. International Journal of Food Microbiology, v. 186, p. 74-83, 2014.

LI, X. et al. Influence of vacum skin packaging on color stability of beef longissimus lomborum compared with vacuum and high-oxygen modified atmosphere packaging. Meat Science, Amsterdam, v. 92, p. 604-609, 2012.

LINARES, M.B.; VERGARA, H. Effect of gas stunning and modified-atmosphere packaging on the quality of meat from Spanish Manchego light lamb. Small Ruminant Research, Milton Keynes, v. 108, p. 87-94, 2012.

LONERGAN, S. M. et al. High Oxygen Modified Atmosphere packaging system induces lipid and myoglobin oxidation and protein polymerization. Meat Science, Amsterdam, v. 85, p. 759-767, 2010.

LOMIWES, D. et al. Small heat shock proteins and their role in meat tenderness: A review. Meat Science, Amsterdam, v. 96, p. 26-40, 2014.

MACEDO, R. E. F., ROSSA, R. S., NUNES, L. C. A. S. Atmosferas modificadas para conservação de carnes frescas: Tendências e aplicabilidade tecnológica do monóxido de carbono. Revista Acadêmica, Ciências Agrárias e Ambientais, Curitiba, v. 7, n. 4, p. 469-482, out./dez. 2009.

MACHADO, M.M. Efeito do congelamento e estocagem sobre a qualidade da carne bovina. 2009, 41f, dissertação (Mestrado em Medicina Veterinária) - Escola de veterinária da Universidade Federal de Minas Gerais, Belo Horizonte, 2009.

MANCINI, R.A.; HUNT, M;C. Current research in meat color. Meat Science, Amsterdam, v. 71, p. 100-121. 2005.

MANTILLA, S. P. S. et al. Atmosfera Modificada E Irradiação: Métodos Combinados De Conservação E Inocuidade Alimentar. Revista Científica Eletrônica de Medicina Veterinária e Zootecnia de Garça - FAMED/FAEF e Editora FAEF, Ano VIII , Número 15, Julho de 2010, Periódico Semestral. 
MARINO, R. et al. Proteolytic pattern of myofibrillar protein and meat tenderness as affected by breed and aging time. Meat Science, Amsterdam, v. 95, p. 281-287, 2013.

MARSIGILIO, B. N. Ovinocultura no Brasil e no Mundo. IEPEC, 2012. Disponível em $<$ http://www.iepec.com/noticia/ovinocultura-de-corte-no-brasil-e-no-mundo> Acesso em 11set-2012.

MYERS, K. et al. The effect of high hydrostatic pressure, sodium nitrite and salt concentration on the growth of Listeria monocytogenes on RTE ham and turkey. Meat Science, Amsterdam, v. 93, p. 263-268, 2013.

MCMILLIN, K. W. Where is MAP Going? A review and future potential of modified atmosphere packaging for meat. Meat Science, Amsterdam , v. 80, p. 43-65, 2008.

MONTEIRO, E.M.; RÜBENSAM, J.; PIRES,G. Avaliação de parâmetros de qualidade da carcaça e da carne de ovinos. In: CONGRESSO BRASILEIRO DE CIÊNCIA E TECNOLOGIA DE CARNES, 1., 2001, São Pedro. Anais... São Pedro : CTC/ITAL, p.98-99, 2001.

MURPHY, K.M.; O'GRADY, M.N; KERRY, J.P. Effect of varying the gas headspace to meat ratio on the quality and shelf-life of beef steaks packaged in high oxygen modified atmosphere packs. Meat Science, Amsterdam, v. 94, p. 447-454, 2013.

NIEMINEN, T.T., et al. Comparison of microbial communities in marinated and unmarinated broiler meat by metagenomics. International Journal of Food Microbiology, v. 157, p. 142-149, 2012.

O'FLYNN, CC. et al. The application of high-pressure treatment in the reduction of phosphate levels in breakfast sausages. Meat Science, Amsterdam, v. 96, p. 633-639, 2014.

OMANA, D.A.; PLASTOW, G.; BETTI, M. Effect of different ingredients on color and oxidative characteristics of high pressure processed chicken breast meat with special emphasis on use of $\beta$-glucan as a partial salt replacer. Innovative Food Science and Emerging Technologies, Amsterdam, v. 12, p. 244-254, 2011.

ORDÓÑEZ, J.A.P. et al. Tecnologia de Alimentos: alimentos de origem animal. Porto Alegre: Artmed, v.1, 279p, 2005.

OSÓRIO, J. C. S; OSÓRIO, M. T. M; SAÑUDO, C. Características sensoriais da carne ovina. Revista Brasileira de Zootecnia, Viçosa, v.38, p.292-300, 2009.

PADULA, M. et al. Embalagens plásticas: controle de qualidade. Campinas: CETEA/ITAL, 202 p., 1989.

PARDI, M. C. Ciência, higiêne e tecnologia da carne. $1^{\circ}$ ed., Goiania: Cegraf-UFG/ Niterói: EDUFF, 1993. 
PATHANIA, A. et al. Antimicrobial activity of commercial marinades against multiple strains of Salmonella spp. International Journal of Food Microbiology, v. 139, p. 214-217, 2010.

PRATA, L.F. Higiene e inspeção de carnes, pescado e derivados. Jaboticabal : FUNEP, 1999. 217p.

REIS, F.A. Atualidades na criação de ovinos no Brasil Central. In: CONGRESSO INTERNACIONAL FEINCO, 5., 2009, São Paulo. Anais... São Paulo: FEINCO, p.114, 2009.

RHOADES, J. et al. Use of marination for controlling Salmonella enterica and Listeria monocytogenes in raw beef. Food Microbiology, London, v. 36, p. 248-253, 2013.

ROSENVOLD, K; WIKLUND, E. Retail colour display life of chilled lamb as affected by processing conditions and storage temperature. Meat Science, Amsterdam, v. 88, p. 354-360, 2011.

RUUSUNEM, $\mathrm{M}$ el al. Reducing the sodium content in meat products: The effect of the formulation in low-sodium ground meat patties. Meat Science, Amsterdam, v. 69, p. 53-60, 2005.

SAEED, S.; FAWTHROP, S.A.; HOWELL, N.K. Electron spin resonance (ESR) study on free radical transfer in fish lipid-protein interaction. Journal of the Science of Food and Agriculture, Chichester, v. 79, p. 1809-1816, 1999.

SAÑUDO, C. et al. Carcass and meat quality in light lambs from different fat classes in the EU carcass classification system. Meat Science, Amsterdam, v.56 p.89-94, 2000.

SARANTÓPOULOS, C.I.G.L., Embalagem a vácuo e com atmosfera modificada para carnes frescas. In: Embalagens para produtos cárneos - ITAL - Campinas, S.P., 1991.

SARANTOPOULOS, C.I.G.L. et al. Embalagens plásticas flexíveis: principais polímeros e avaliação das propriedades, ed CETEA/ITAL, 267p., 2002.

SEBRAE. Produção de carne ovina pode ser mais rentável que bovina. Publicado em 26-032013. Disponível em <http://www.sebraesp.com.br/index.php/165-produtosonline/administracao/publicacoes/artigos>, Acesso em 26-Ago-2015.

SHERIDAN, J. J. et al. The Effect of Vacuum and Modified Atmosphere Packaging on the Shelf-life of Lamb Primals, Stored at Different Temperatures. Meat Science, Amsterdam, v.45, p. 107-117, 1997.

SILVA, V. C. et al. Suplementação de ovinos com vitamina e sua repercussão na qualidade da carne: revisão. Ciência Animal, v. 21, ed. 2, p. 135-142, 2011.

SINGH, P. et al. Understanding critical factors for the quality and shelf-life of map fresh meat: a review. Critical Reviews in Food Science and Nutrition, v. 51:2, p. 146177, DOI: 10.1080/10408390903531384, 2011. 
SOBRINHO, A. G. S. et al. Características de Qualidade da Carne de Ovinos de Diferentes Genótipos e Idades ao Abate. Revista Brasileira de Zootecnia, Viçosa, v.34, n.3, p.1070-1078, 2005.

SHAREDEH, D. et al. Effects of $\mathrm{pH}$ and $\mathrm{NaCl}$ levels in a beef marinade on physicochemical states of lipids and proteins and on tissue microstructure. Meat Science, Amsterdam, v. 110, p. 24-31, 2015.

TAJKARIMI, M.M., IBRAHIM, S.A., CLIVER, D.O. Antimicrobial herb and spice compounds in food. Food Control, v. 21, p. 1199-1218, 2010.

TOOMIK, P. et al. The effect of tenderizing acids on linoleic acid oxidation during marination of pork. Meat Science, Amsterdam, v. 92, p. 870-873, 2012.

TORREZAN, R. Uso da tecnologia de alta pressão para a inativação de microrganismos em produtos cárneos. B.CEPPA, Curitiba, v. 21, n.2, p. 249-266, jul/dez, 2003.

TRINDADE, M. A.; GRESSONI JÚNIOR, I. Bioquímica da Carne: Bases Científicas e Implicações Tecnológicas. In: KOBLITZ, M. G. B. Bioquímica de Alimentos: Teoria e Aplicações Práticas. Rio de Janeiro: Guanabara Koogan, p. 191-233, 2008.

TRINDADE, M. A. et al. Active packaged lamb with oxygen scavenger/carbon dioxide emitter sachet: physical-chemical and microbiological stability during refrigerated storage. Brazilian Journal of Food Technology, Campinas, v. 16, n. 3, p. 216-225, jul./set. 2013.

USDA- United States Department of Agriculture. Food Standards and Labeling Policy Book. Food Safety And Inspection Service, 2005. Available in <http://www.fsis.usda.gov/OPPDE/larc/Policies/Labeling_Policy_Book_082005.pdf> Access in 14-april-2015.

USDA- United States Department of Agriculture. Livestock and Poultry: World market and trades. 2015. Disponível em <

http://apps.fas.usda.gov/psdonline/circulars/livestock_poultry.PDF>Acesso em 10 dez. 2015.

VENTURINI, A.C., et al. The effects of residual oxygen on the storage life of retail-ready fresh beef steaks masterpackaged under a $\mathrm{CO}_{2}$ atmosphere. Journal of Food Science, Estados Unidos, v. 71, p. 5560-566, n. 7, 2006

VERGARA, A.; GALLEGO, L. Effect of gas composition in atmosphere packaging on the meat quality of Spanish Manchega lamb. Journal of the Science of Food and Agriculture, London, v. 81, n. 14, p. 1353-1357, 2001.

VIEGAS. A., Consumo per capita de carne ovina no Brasil é de apenas 400 gramas por ano. Do Agrodebate. Disponível em < http://www.agrodebate.com.br/_conteudo/2012/06/noticias/2949-consumo-per-capitade-carne-ovina-no-brasil-e-de-apenas-400-gramas-por-ano.html > Acesso em 12-set2012. 
XIMENES, L. J.F.. Ciência e Tecnologia na Pecuária de Caprinos e Ovinos. Série BNB Ciência e Tecnologia, v. 05, Fortaleza: Banco do Nordeste do Brasil, 2010.

YUSOP, S.M. et al. Effect of marinating time and low $\mathrm{pH}$ on marinade performance and sensory acceptability of poultry meat. Meat Science, Amsterdam, v. 85, p. 657$663,2010$.

YUSTE, J. et al. Listeria innocua and aerobic mesophiles during chill storage of inoculated mechanically recovered poultry meat treated with high hydrostatic pressure. Meat Science, Amsterdam, v. 53, p. 251- 257, 1999.

ZARAI, Z. et al. Antioxidant and antimicrobial activities of various solvent extracts, piperine and piperic acid from Piper nigrum. LWT - Food Science and Technology, London, v. 50, p. 634-641, 2013. 
2. EFEITO DA TECNOLOGIA DE ATMOSFERA MODIFICADA SOBRE A QUALIDADE DA CARNE DE CORDEIRO REFRIGERADA 


\section{RESUMO}

Os principais aspectos a serem controlados, a fim de manter a qualidade da carne são a segurança microbiológica, a estabilidade à oxidação e a coloração. Esta pesquisa teve como objetivo avaliar o efeito da embalagem de atmosfera modificada (ATM), com diferentes concentrações dos gases $\mathrm{O}_{2}$ e $\mathrm{CO}_{2}$, na manutenção dos parâmetros de qualidade da carne ovina armazenada sob refrigeração. Músculos Longissimus lumborum de cordeiros foram embaladas em cinco condições diferentes de ATM: $15 \%$ $\mathrm{O}_{2}+85 \% \mathrm{CO}_{2} ; 30 \%$ de $\mathrm{O}_{2}+70 \%$ de $\mathrm{CO}_{2} ; 45 \%$ de $\mathrm{O}_{2}+55 \%$ de $\mathrm{CO}_{2} ; 60 \%$ de $\mathrm{O}_{2}+$ $40 \%$ de $\mathrm{CO}_{2}$; Vácuo (controle). A composição do gás na embalagem, a composição nutricional da carne, a cor, o valor de $\mathrm{pH}$, a oxidação de lípideos, a perda de peso no cozimento, a força de cisalhamento e a contaminação microbiana (Salmonela, Estafilococos coagulase positiva, coliformes temotolerantes a $45^{\circ} \mathrm{C}$, bactérias ácido lácticas, psicrotróficos aeróbios e anaeróbios) foram avaliados durante armazemanento refrigerado $\left(1 \pm 1^{\circ} \mathrm{C}\right)$. A percepção dos consumidores foi analisada pelo teste de aceitação sensorial. Os dados foram processados através de análise de variância ANOVA e teste de Tukey a 5\% de significância. A embalagem a vácuo foi mais eficaz para preservar a mioglobina e proteger as amostras contra a oxidação lipídica. No entanto, amostras submetidas a $45 \% \quad \mathrm{O}_{2}+55 \% \quad \mathrm{CO}_{2}$ apresentaram melhor cor nos primeiros sete dias de armazenamento, e não houve diferença ( $p>0,05)$ na oxidação lipídica entre amostras embalados a vácuo e as embaladas em $30 \% \mathrm{O}_{2}+70 \% \mathrm{CO}_{2} \mathrm{e}$ $45 \%$ de $\mathrm{O}_{2}+55 \%$ de $\mathrm{CO}_{2} \cdot \mathrm{CO}_{2}$ mostrou-se muito eficaz contra a deterioração microbiana da carne. As amostras em $15 \% \mathrm{O}_{2}+85 \% \mathrm{CO}_{2}$ tiveram 18 dias de vida de prateleira e foram preferidas na maioria dos atributos avaliados pelos consumidores. Percebeu-se que a redução da deterioração microbiana é a única vantagem da utilização da ATM em relação ao vácuo. 
Palavras chave: Carne, embalagens, vida de prateleira, estabilidade. 


\begin{abstract}
The main aspects to be controlled in order to make the meat be perceived by consumers as a quality product are microbiological safety, stability to oxidation and colour. This research aimed to evaluate the effect of Modified Atmosphere Packaging (MAP), on the maintenance of quality parameters of meat stored under refrigeration. Longissimus lumborum were packed in five different conditions of MAP: $15 \% \mathrm{O}_{2}+$ $85 \% \mathrm{CO}_{2} ; 30 \% \mathrm{O}_{2}+70 \% \mathrm{CO}_{2} ; 45 \% \mathrm{O}_{2}+55 \% \mathrm{CO}_{2} ; 60 \% \mathrm{O}_{2}+40 \% \mathrm{CO}_{2} ;$ Vacuum (control). The gas composition in the packaging, the nutritional composition of the meat, colour, $\mathrm{pH}$, lipid oxidation, water loss, shear force and microbiological loads were measured. The perception of the consumers was analyzed by sensorial test. Data were processed through ANOVA and Tukey's test at 5\% of significance, by using SAS. Vacuum packaging was more effective to preserve myoglobin and protect samples against lipid oxidation. However, $45 \% \mathrm{O}_{2}+55 \% \mathrm{CO}_{2}$ samples showed better colour in the first seven days of storage, and no difference ( $p>0.05)$ was found in lipid oxidation between vacuum packed samples and the ones in $30 \% \mathrm{O}_{2}+70 \% \mathrm{CO}_{2}$ and $45 \% \mathrm{O}_{2}+$ $55 \% \mathrm{CO}_{2} . \mathrm{CO}_{2}$ was very effective against spoilage in the meat. Samples in $15 \% \mathrm{O}_{2}+$ $85 \% \mathrm{CO}_{2}$ had 18 days of shelf life and were preferred in the most attributes evaluated by consumers. I was observed that the reduction in spoilage is the unique improvement achieved for MAP when compared to vacuum.
\end{abstract}

Key words: Meat, packaging, shelf life, stability. 


\subsection{INTRODUÇÃO}

A produção e o consumo de carne ovina no Brasil ainda é uma atividade bastante reduzida, segundo dados da Associação Brasileira de Criadores de Ovinos (ARCO) (CORRÊA, 2012). Entretanto, na perspectiva mundial, o consumo deste tipo de carne vem aumentando desde 1965, com destaque para a China, que é o maior produtor mundial e para a Nova Zelândia que é o maior exportador (BRESTER, 2012).

A fim de favorecer a comercialização da carne ovina deve-se atender às exigências do consumidor, elevando-se a satisfação e aceitabilidade do produto no mercado. O crescente interesse do consumidor pela carne ovina deve-se, entre outros fatores, à busca por carne macia, com pouca gordura e muito músculo (SILVA SOBRINHO, 2001). Acrescenta-se a estes fatores, uma maior exigência por produtos frescos ou minimamente processados.

A carne é um alimento altamente nutritivo o que favorece o crescimento de microrganismos patogênicos e deteriorantes. Camo, Beltrán e Roncalés, (2008) comentam que a vida útil da carne de cordeiro refrigerada não excede 10 dias devido ao processo de deterioração microbiano. Pode também ocorrer oxidação dos ácidos graxos levando à produção de aroma e sabor não desejáveis. Além disso, a oxidação lipídica em carnes tem recebido mais atenção recentemente devido à possibilidade de participação dos produtos da oxidação no desenvolvimento doenças coronarianas, câncer e derrame cerebral (LIRA et al., 2000).

Uma das funções mais importantes das embalagens de alimentos é proteger o produto contra efeitos deteriorativos, como descoloração, desenvolvimento de offflavors, perda de nutrientes, mudança de textura e patogenicidade. A qualidade de alimentos embalados está diretamente relacionada com o alimento e os atributos do 
material da embalagem, portanto esses materiais devem ser desenvolvidos para manter as características desejáveis do alimento durante o armazenamento (MCMILLIN, 2008).

Um tipo de embalagem que vem ganhando destaque na indústria da carne é a embalagem com atmosfera modificada (ATM), a qual pode reduzir o crescimento microbiano através da atuação bacteriostática do $\mathrm{CO}_{2}$ e pode ser ajustada para proporcionar a manutenção de características físico-químicas desejáveis no produto, como por exemplo, a manutenção da cor vermelha pelo uso de oxigênio.

Uma barreira associada à utilização de ATM é a refrigeração, a qual é utilizada principalmente para minimizar alguns processos bioquímicos e biológicos dos tecidos que continuam em atividade, tais como a respiração e a oxidação lipídica (JAYAS e JEYAMKONDAN, 2002). De acordo com Devlieghere, Debevere e Impe (1998), o $\mathrm{CO}_{2}$ tem sido um dos componentes mais utilizados por apresentar atividade antimicrobiana e por ter capacidade de ser parcialmente dissolvido na água e na gordura do alimento, quando este é estocado em baixas temperaturas.

A temperatura, a concentração de gases e a umidade relativa na embalagem são os fatores extrínsecos de maior influência sobre a microbiota e a determinação da vida útil do produto (ROSA, 2002). O estudo realizado por Fernandes et al (2014), que avaliou o efeito do vácuo, $75 \%$ de $\mathrm{O}_{2}+25 \%$ de $\mathrm{CO}_{2}$ e $100 \%$ de $\mathrm{CO}_{2}$ sobre a estabilidade dos lombos de cordeiro armazenados a $1 \pm 1^{\circ} \mathrm{C}$ durante 28 dias, concluiu que amostras embaladas em sistemas contendo $100 \%$ de $\mathrm{CO}_{2}$ apresentaram maior estabilidade, mas menor preferência quanto à aparência.

Esta pesquisa teve como objetivo avaliar o efeito da tecnologia de atmosfera modificada, pelo uso de diferentes combinações dos gases oxigênio de gás carbônico, sobre a estabilidade de parâmetros físico-químicos, microbiológicos e sensoriais da carne ovina armazenada sob refrigeração. 


\subsection{MATERIAIS E MÉTODOS}

\subsubsection{Matérias primas}

Duzentos e vinte e cinco lombos de cordeiro (Longissimus lumborum) Textel $\mathrm{x}$ Santa Inês, com cinco meses de idade, com peso vivo na faixa de 35 a $40 \mathrm{Kg}$ foram adquiridos em um frigorífico localizado no estado de São Paulo- Brasil. Os cordeiros machos foram abatidos com o peso médio de carcaça de $18 \mathrm{Kg}$. Os cortes foram obtidos entre a $1^{\mathrm{a}}$ e $6^{\mathrm{a}}$ vértebras lombares, sendo estes lombos desossados e limpos. Logo em seguida as amostras foram encaminhadas para a FZEA/USP, para acondicionamento sob a tecnologia de atmosfera modificada.

\subsubsection{Caracterização da embalagem}

Gramatura e espessura dos filmes alta barreira: a espessura foi medida em triplicata com um micrômetro digital marca Digimess modelo 130.125. Os resultados foram expressos em micrômetros $(\mu \mathrm{m})$. Os ensaios de gramatura foram realizados em balança analítica em triplicata e os resultados foram expressos em gramas por metro quadrado $\left(\mathrm{g} \cdot \mathrm{m}^{-2}\right)$

Estanqueidade: Foi realizada de acordo com Padula et al. (1989) em triplicata para cada repetição. 


\subsubsection{Acondicionamento e estudo de vida útil}

Lombos com aproximadamente $150 \mathrm{~g}$ foram acondicionadas em bandejas de poliestireno expandido tipo Dry-lock perfurada para a drenagem de líquidos (Marca LINPAC, Modelo 21P LinStar) com medidas de 140 x 178 × 25 mm e absorção de $25 \pm 5$ g de água. As bandejas foram colocadas individualmente dentro de sacos plásticos de filme alta barreira para carne resfriada contendo sete camadas à base de EVA (etil-vinilacetato), PVDC (policloreto de vinilideno) e EVOH (etil vinil álcool), com dimensões de $200 \mathrm{~mm}$ x $400 \mathrm{~mm}$ (Código BB2800, Marca CRYOVAC). De acordo com o fabricante, as principais propriedades desta embalagem multicamadas são: Espessura nominal de 48 a $62 \mu \mathrm{m}$; taxa de permeabilidade máxima ao $\mathrm{O}_{2}$ de $2,5 \mathrm{~cm}^{3} / \mathrm{m}^{2}$.dia (1 $\operatorname{atm} / 23^{\circ} \mathrm{C} / 0 \%$ UR) e taxa de permeabilidade máxima ao vapor d'água $10 \mathrm{gH}_{2} \mathrm{O} / \mathrm{m}^{2}$.dia (1 atm $\left./ 38^{\circ} \mathrm{C} / 90 \% \mathrm{UR}\right)$. Os cortes foram armazenados em cinco diferentes condições de Atmosfera Modificada (ATM): $\mathrm{A}=15 \% \mathrm{O}_{2}+85 \% \mathrm{CO}_{2}, \mathrm{~B}: 30 \% \mathrm{O}_{2}+70 \% \mathrm{CO}_{2} ; \mathrm{C}=$ $45 \% \mathrm{O}_{2}+55 \% \mathrm{CO}_{2} ; \mathrm{D}=60 \% \mathrm{O}_{2}+40 \% \mathrm{CO}_{2} ; \mathrm{E}=$ a vácuo (controle), sendo destinados 45 lombos para cada tratamento. As carnes foram estocadas a $1 \pm 1^{\circ} \mathrm{C}$ em estufas BOD (marca Fanem modelo 347CD).

As análises físico-químicas para a verificação das alterações de qualidade das amostras foram realizadas a cada sete dias totalizando quatro pontos (intervalos), correspondentes aos tempos consecutivos de armazenamento (0, 7, 14 e 21 dias), as análises microbiológicas foram realizadas duas vezes por semana pelo mesmo período de tempo. O experimento completo foi repetido três vezes. 


\subsubsection{Composição centesimal}

A metodologia oficial da A.O.A.C., (1998) foi utilizada para determinação de proteína (981.10), gordura (991.36), umidade (950.46) e cinzas (920.153). Os ensaios foram realizados em triplicata para cada experimento.

\subsubsection{Composição gasosa}

A composição gasosa no interior da embalagem foi determinada em triplicata para cada tratamento utilizando um analisador de gás portátil (Marca Dansensor, Modelo CheckPoint O2/CO2), que realiza a leitura e a determinação dos gases através da punção da embalagem com uma agulha, de acordo com o procedimento descrito por Sarantópoulos et al. (2002).

\subsubsection{Cor Objetiva}

As amostras de cada tratamento foram submetidas à avaliação de cor utilizandose espectrofotômetro portátil (mod. MiniScan XE, marca HunterLab), através da escala $L^{*}, a^{*}, b^{*}$, do sistema CIE Lab, utilizando-se o iluminante D65, ângulo de observação de $10^{\circ}$ e abertura de célula com $30 \mathrm{~mm}$, para cálculo dos valores $\mathrm{L}^{*}$, a* e $\mathrm{b}^{*}$ médios de 5 leituras, imediatamente e após 30 minutos de exposição ao ar atmosférico, a fim de permitir a avaliação do efeito da concentração de $\mathrm{O}_{2}$ na cor da carne e a capacidade de reblooming da mioglobina, respectivamente, em cada tratamento. 


\subsubsection{Valor de pH}

As medições de $\mathrm{pH}$ foram realizadas com a utilização de pHmetro (Marca Hanna, Modelo HI 99163, Woonsocket - USA) com eletrodo combinado para leitura em triplicata com perfuração de 3 pontos de cada tratamento.

\subsubsection{Oxidação Lipídica}

O método de Vyncke (1970) foi utilizado para medir o desenvolvimento de substâncias reativas ao ácido tiobarbitúrico (TBARS) e os resultados foram expressos em mg malonaldeído $\mathrm{Kg}^{-1}$ amostra. A análise foi realizada em sextuplicata para cada tratamento.

\subsubsection{Perda de peso por cocção e Força de cisalhamento}

Inicialmente as carnes foram pesadas e assadas em forno elétrico à temperatura de $180^{\circ} \mathrm{C}$ até que o centro geométrico atingisse a temperatura de $36^{\circ} \mathrm{C}$, e então foram viradas e assadas até que o centro geométrico atingisse $72^{\circ} \mathrm{C}$. As carnes foram retiradas do forno e deixadas à temperatura ambiente por cerca de 30 minutos, quando foram pesadas novamente para determinação de perdas de peso por cocção através da equação:

$$
\mathrm{PPC}=\frac{\text { Peso } \text { inicial }- \text { Peso Final }}{\text { Peso } \text { inicial }} \times 100
$$

Equação 1

Após a cocção e pesagem, as amostras assadas foram cortadas em paralelepípedos de $2 \times 1 \times 1 \mathrm{~cm}$ no sentido paralelo às fibras musculares para cada uma 
das amostras e utilizou-se o acessório "Warner Bratzler" para a determinação da força de cisalhamento, o qual foi expresso em $\mathrm{Kg}$ ou $\mathrm{Kgf} / \mathrm{cm}^{2}$. Para cada tratamento foram realizadas oito medidas.

\subsubsection{Análises Microbiológicas}

Para o estudo da qualidade microbiológica, foram avaliadas a presença ou quantidade de cada microrganismo. Os testes foram feitos em duplicata para cada microrganismo em cada tratamento aplicado. Utilizou-se o ágar Lactobacilli deMan, Rogosa and Sharpe (MRS) (Acumedia, Neogen Corporation) para plaqueamento de bactérias lácticas, Petrifilm ${ }^{\mathrm{tm}} 3 \mathrm{M}$ Health Care para plaqueamento de psicrotróficos anaeróbios e aeróbios ( Aerobic count plate, 6400), Coliformes termotolerantes a $45^{\circ} \mathrm{C}$ (Coliform count plate, 6410) e Estafilococos coagulase positiva (STX, 6490). A conclusão da inocuidade microbiana do produto e avaliação de sua vida de prateleira foi feita após a contagem das placas incubadas a $21^{\circ} \mathrm{C} / 72 \mathrm{~h}$ para psicrotróficos aeróbios e anaeróbios, $45^{\circ} \mathrm{C} / 24 \mathrm{~h}$ para coliformes termotolerantes a $45^{\circ} \mathrm{C}, 37^{\circ} \mathrm{C} / 24 \mathrm{~h}$ para estafilococos coagulase positiva e $37^{\circ} / 48 \mathrm{~h}$ para bactérias lácticas. O Kit Bax for Salmonella foi utilizado para determinar presença de Salmonela, sendo que o procedimento de enriquecimento foi realizado diluindo-se $25 \mathrm{~g}$ de amostra em $225 \mathrm{~mL}$ de água peptonada enriquecida e incubando-se a $37^{\circ} \mathrm{C} / 24 \mathrm{~h}$, antes de realizar a leitura

através do equipamento DuPont Qualicon Bax® System. Os resultados foram comparados com a RDC n 12 (BRASIL, 2001). 


\subsubsection{Análise Sensorial}

Nos períodos de dois dias e nove dias de estocagem foram realizados os testes de aceitação e análise visual utilizando teste de ordenação de preferência. As fichas utilizadas nos testes estão disponíveis nos anexos A e B. Os consumidores foram recrutados por meio do questionário disponível nos Anexos C e D. A análise foi submetida ao comitê de ética para aprovação sob o número: CAAE 120685 12.0.0000.5422.

Para os testes de aceitação as amostras foram imersas em salmoura (5\% de $\mathrm{NaCl})$ durante 30 minutos e em seguidas assadas em forno elétrico à temperatura de $180^{\circ} \mathrm{C}$ até atingirem temperatura de $36^{\circ} \mathrm{C}$ no centro geométrico. Em seguida virou-se o lado das amostras na bandeja e continuou-se o cozimento até que a temperatura interna atingisse $72^{\circ} \mathrm{C}$. As amostras foram mantidas em estufa à $60^{\circ} \mathrm{C}$ por no máximo 30 minutos até serem servidas, em blocos completos aleatorizados. Foi empregada a escala hedônica de nove pontos, sendo avaliados os atributos aroma, textura, suculência, sabor e qualidade global (MEILGAARD, CIVILLE e CARR, 1991). Para o teste visual de ordenação crescente de preferência (FERREIRA et al., 2000), as amostras dos cinco tratamentos foram submetidas à observação simultânea em suas respectivas embalagens, apresentadas em ordem aleatória. Os testes de aceitação foram realizados em cabines com iluminação vermelha e os testes visuais com luz branca. Sessenta consumidores de carne ovina foram recrutados para os testes sensoriais.

\subsubsection{Análise estatística}

Os dados obtidos foram tratados com o programa estatístico SAS (Statistic Analisy System), versão 8.02, por análise de variância ANOVA e teste de Tukey, ao 
nível de 5\% de confiança. As respostas experimentais obtidas foram submetidas a ajustes de modelos de regressão linear para verificar a tendência de comportamento das amostras nos sistemas de embalagem, complementando-se as análises com tabelas e/ou gráficos.

\subsection{RESULTADOS E DISCUSSÃO}

\subsubsection{Caracterização da embalagem}

Os valores obtidos para espessura e gramatura dos filmes são apresentados na Tabela 1. Os testes de estanqueidade foram realizados com o intuito de verificar a presença de vazamento na embalagem causado por deficiência na soldagem do plástico. Nenhum vazamento foi encontrado em nenhum dos experimentos.

Tabela 1 - Medidas de gramatura e espessura para os filmes alta barreira empegados no acondicionamento de lombos de cordeiro aramazenados sob refrigeração.

\begin{tabular}{l|l}
\hline Parâmetro & $\mathrm{M} \pm \mathrm{DP}$ \\
\hline Gramatura $\left(\mathrm{g} . \mathrm{m}^{-2}\right)$ & $57 \pm 2$ \\
Espessura $(\mu \mathrm{m})$ & $68,6 \pm 1$ \\
\hline $\begin{array}{l}\text { M } \pm \text { DP: média } \pm \text { desvio padrão. Ensaios realizados em triplicata com } 10 \text { medidas para espessura } \\
\text { Fonte: Própria autoria. }\end{array}$
\end{tabular}

\subsubsection{COMPOSIÇÃO CENTESIMAL}

A composição média das amostras representativas de lombo de cordeiro é apresentada na Tabela 2.

Os resultados da composição centesimal obtidos, são próximos aos encontrados por Monteiro, Rübensam e Pires (2001), que avaliando parâmetros qualitativos da carne de cordeiros mestiços Texel x Corriedale criados em regime de pasto e abatidos aos 
nove meses de idade, encontraram teores de umidade de 73,8\%, proteína $22,0 \% ; 3,2 \%$ de lipídeos, e 1,0\% de matéria mineral no músculo Longissimus dorsi. De acordo com Prata (1999), a composição centesimal da carne ovina apresenta valores médios de $75 \%$ de umidade, $19 \%$ de proteína, $4 \%$ de gordura e $1,1 \%$ de matéria mineral. Fernandes et al. (2014), estudou lombos (Longissimus lumborum) de cordeiros Santa Inês x Dopper abatidos entre cinco e seis meses de idade. Eles encontraram $75 \%$ de umidade, $21,20 \%$ de proteína, 2,48\% de lipídeos e 1,05\% de cinzas. Esses valores podem oscilar com o estado de acabamento do animal, resultando em diminuição das porcentagens de proteína e água e elevação do teor de gordura na carne. Desta forma, com maiores pesos ao abate há tendência em aumentar o teor de gordura e diminuir o de água na carne (BONAGURIO et al., 2001; SOUZA et al., 2001).

Tabela 2 - Composição centesimal do lombo de cordeiro $(\% \mathrm{~m} / \mathrm{m})$

\begin{tabular}{lc}
\hline Composição & Média \\
\hline Umidade & $73,6 \pm 0,5$ \\
Proteínas & $21,3 \pm 0,3$ \\
Lipídeos & $3,3 \pm 0,3$ \\
Cinzas & $1,07 \pm 0,06$
\end{tabular}

M \pm DP: Média \pm Desvio Padrão. Ensaios realizados em triplicata para cada repetição (rep).

Fonte: Própria autoria.

\subsubsection{Composição gasosa}

As variações dos teores de oxigênio e gás carbônico no espaço livre da embalagem durante o tempo de armazenagem são mostradas nas Figuras 2 e 3, respectivamente. 
Figura 2 - Variação do teor de oxigênio dentro das embalagens durante o período de estocagem refrigerada.

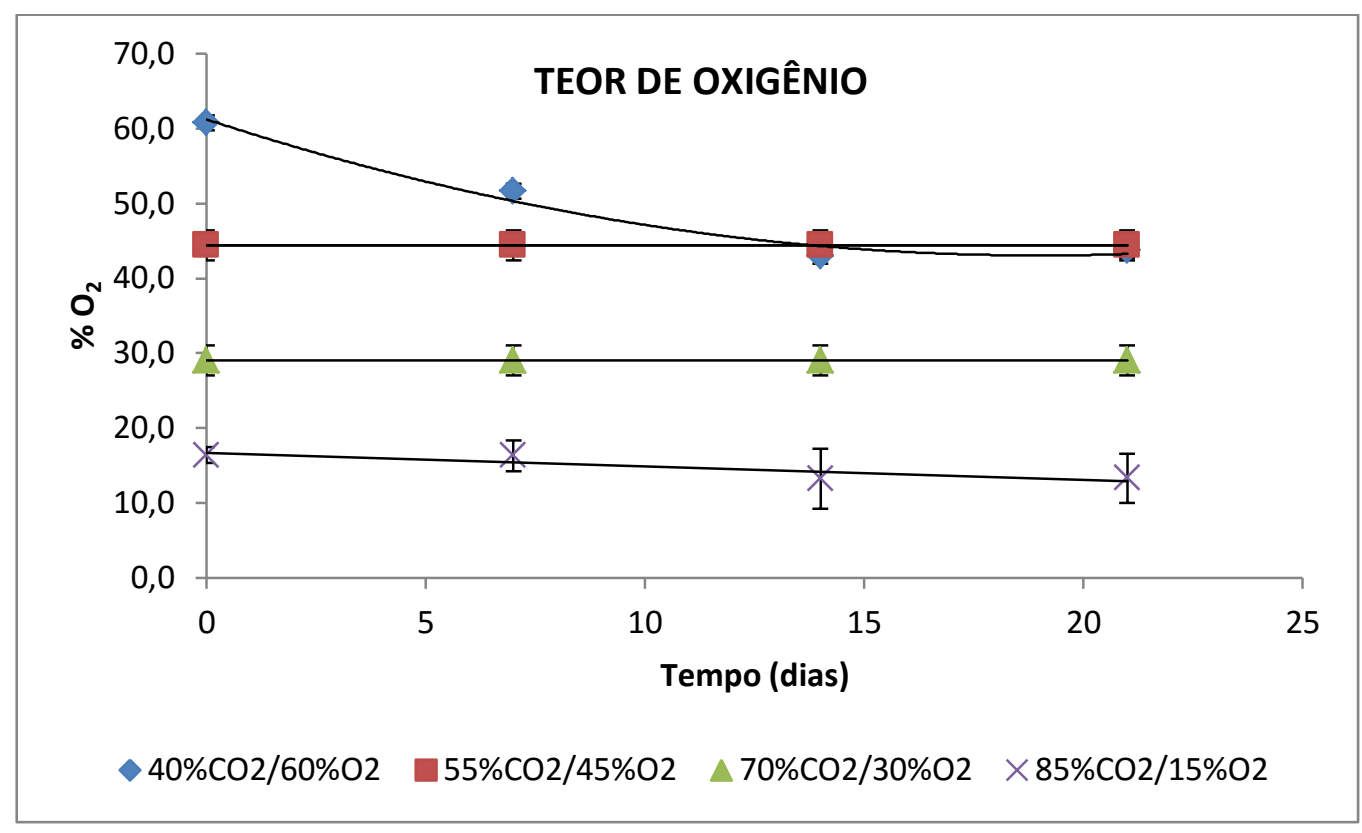

Fonte: Própria autoria

Figura 3- Variação do teor de oxigênio dentro das embalagens durante o período de estocagem refrigerada

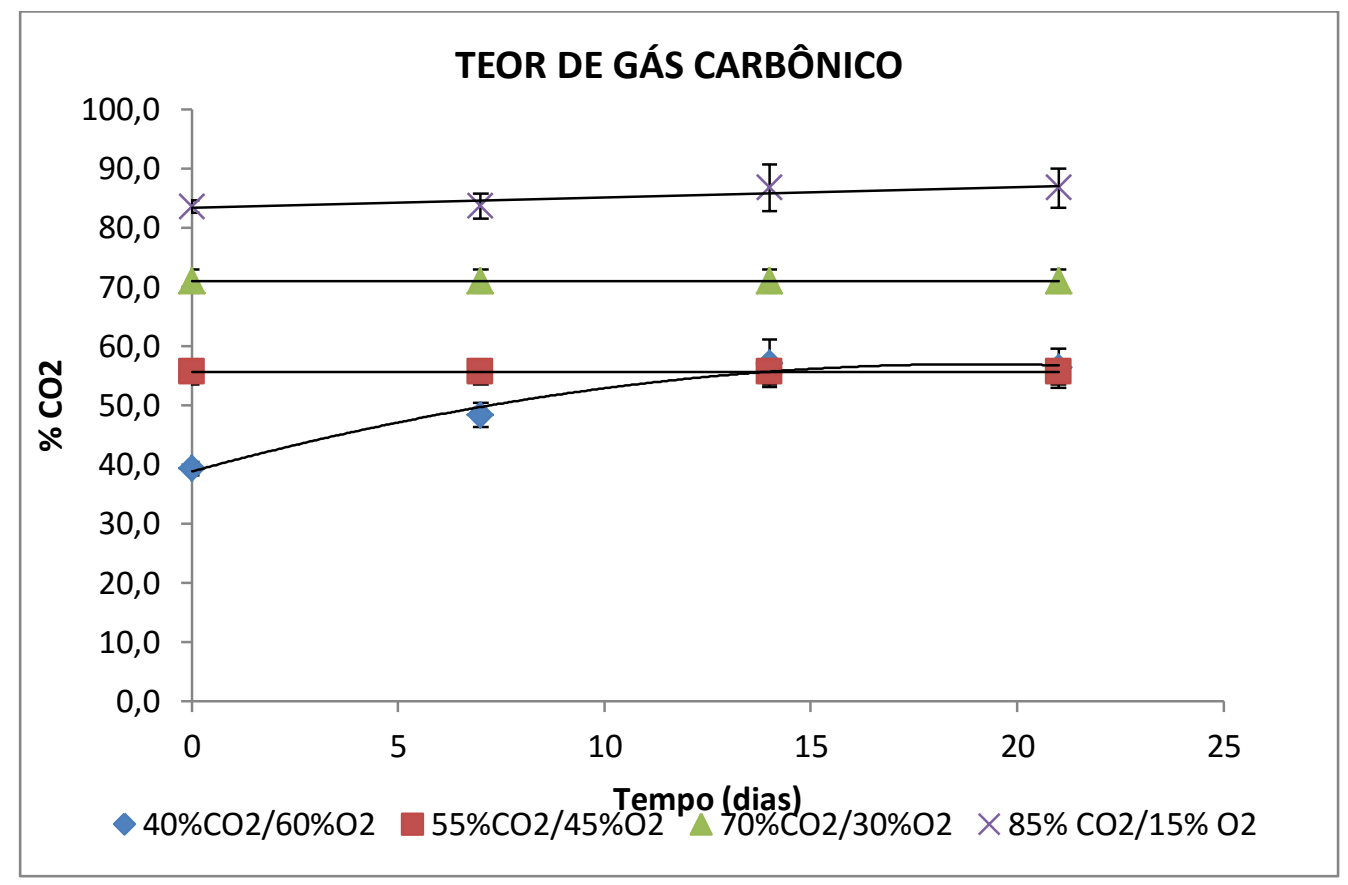

Fonte: Própria autoria 
O tratamento que conferiu maior variação de composição gasosa ao longo do período de estocagem foi aquele contendo $60 \% \mathrm{O}_{2}+40 \% \mathrm{CO}_{2}$. Detectou-se variação significativa na composição gasosa das embalagens para essas amostras $(p<0,05)$, nas quais a redução de $\mathrm{O}_{2}$ ao longo do tempo pode ser explicada por um modelo quadrático $(\mathrm{p}<0,05)$. Detectou-se, também variação significativa na composição de gases nas embalagens das amostras acondicionadas sob $45 \% \mathrm{O}_{2}+55 \% \mathrm{CO}_{2}(\mathrm{p}<0,05)$, nas quais a redução de $\mathrm{O}_{2}$ ao longo do tempo pode ser explicada por uma reta $(\mathrm{p}<0,05)$. Esse fato já era esperado visto que há participação do oxigênio nas reações de oxidação das amostras além de sua absorção pela carne e uso por microrganismos aeróbios (JAKOBSEN; BERTELSEN, 2000). Amostras embaladas em atmosfera contendo 60\% $\mathrm{O}_{2}+40 \% \mathrm{CO}_{2}$ tiveram um maior crescimento microbiano no período inicial de estocagem, quando o nível de oxigênio no interior da embalagem era alto e favoreceu o crescimento de microrganismos aeróbios. Essas amostras atingiram o limite máximo permitido de contaminação no décimo primeiro dia de estocagem. De acordo com Jakobsen e Bertelsen (2002) a concentração de $\mathrm{CO}_{2}$ no espaço livre da embalagem tende a diminuir durante a estocagem devido a sua absorção pelo músculo e pela gordura. De acordo com estes autores, essa absorção ocorre até que a saturação ou o equilíbrio seja alcançado. As trocas gasosas entre embalagem e ambiente contribuem em baixa escala para a variação, tendo em vista a baixa permeabilidade a gases do material utilizado. Para as demais composições gasosas não houve variação significativa $(p>0,05)$ ao longo dos 21 dias de armazenamento a $1^{\circ} \mathrm{C}$.

\subsubsection{Cor objetiva}

As medições de cor nas amostras foram realizadas em dois intervalos: imediatamente após a abertura das embalagens (tempo zero) e após 30 minutos de 
exposição ao ar atmosférico. Para o tempo imediatamente após a abertura da embalagem houve diferença significativa $(p<0,05)$ nos parâmetros $L^{*}$ e $b^{*}$ em relação ao tempo de estocagem para todos os tratamentos. Não foi verificada diferença significativa $(\mathrm{p}>0,05)$ nesses parâmetros entre as amostras nos diferentes tratamentos. No entanto, as variações dos valores de $\mathrm{L}^{*}$ e $\mathrm{b}^{*}$ em função do tempo somente puderam ser explicadas por polinômios de terceiro grau, não representando uma tendência clara de aumento ou redução durante o período avaliado. A média do valor de $\mathrm{L}^{*}$ entre os tratamentos no tempo zero de estocagem foi $41,0 \pm 0,8$ e no tempo final $44,6 \pm 0,8$. A média do valor de $b^{*}$ no tempo zero de estocagem foi 15,5 \pm 0,6 e no tempo final 14,6 \pm 0,3. Para o valor de $\mathrm{a}^{*}$ imediatamente após a abertura das embalagens, foi encontrada diferença significativa $(\mathrm{p}<0,05)$ entre as amostras somente no tempo final de armazenamento (21 dias de estocagem refrigerada), sendo que as amostras embaladas a vácuo apresentaram maior intensidade de cor vermelha no final do período de estudo.

Foi verificada diferença significativa $(\mathrm{p}<0,05)$ nos parâmetros $\mathrm{L}^{*} \mathrm{e} \mathrm{a}^{*}$, em relação ao tempo de estocagem e entre tratamentos, nas medidas tomadas após 30 minutos de exposição ao ar atmosférico. Estes resultados podem ser observados nas Figuras 4 e 5 . Para o valor de luminosidade $\left(L^{*}\right)$, houve variação significativa $(p<0,05)$ entre tratamentos para o tempo de 14 dias de estocagem. $\mathrm{O}$ maior valor de $\mathrm{L}^{*}$ no tempo 14 dias foi observado para o tratamento $30 \% \mathrm{O}_{2}+70 \% \mathrm{CO}_{2}$. De modo geral esse foi o tratamento que expressou os maiores valores para o parâmetro luminosidade durante todo o período de estocagem refrigerada. Amostras dos tratamentos Vácuo e $45 \% \mathrm{O}_{2}+$ $55 \% \mathrm{CO}_{2}$ exibiram os menores valores de $\mathrm{L}^{*}$ ao final do experimento. 
Figura 4- Variação do valor de $L^{*}$ de lombos de cordeiro armazenados em atmosfera modificada e armazenados sob refrigeração, 30 min após a abertura da embalagem durante todo o período de estocagem.

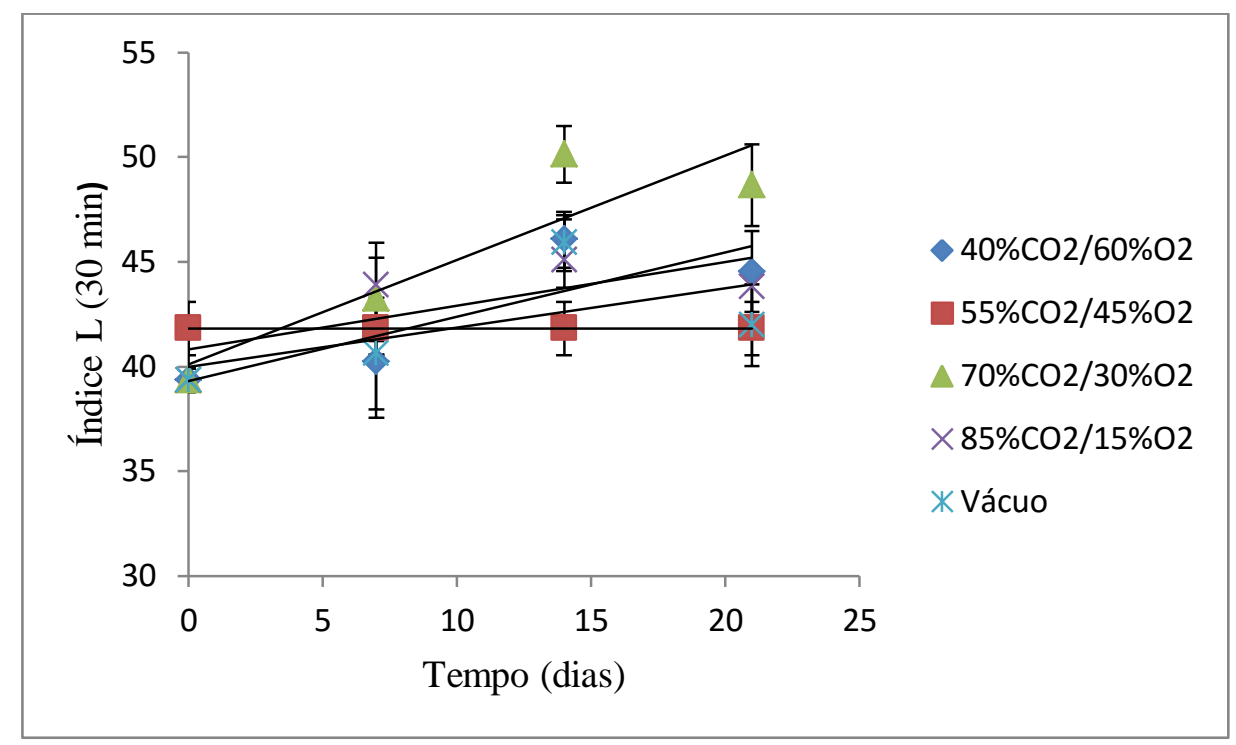

Fonte: Própria autoria

A análise de variância mostrou diferença significativa $(p<0,07)$ no valor de $a^{*}$ entre todos os tratamentos. Observou-se queda constante da intensidade de cor vermelha ao longo do tempo $(\mathrm{p}<0,05)$ para todos os tratamentos exceto o vácuo $(\mathrm{p}<0,05)$ durante todo o período de estocagem. Esperava-se que amostras submetidas a maiores concentrações de oxigênio exibissem maiores valores de $a^{*}$, o que de fato ocorreu até o sétimo dia de estocagem. Entretanto, após esse período todas as amostras apresentaram queda constante desse parâmetro com exceção do vácuo, o que pode indicar que houve oxidação das moléculas de mioglobina restringindo sua capacidade de oxigenação para formação da oximioglobina e consequente geração da cor vermelha brilhante.

As Figuras 6 e 7 ilustram a coloração das amostras no primeiro (Figura 6) e no décimo quarto (Figura 7) dias de estocagem refrigerada. Percebe-se que no início do armazenamento refrigerado as amostras com maior teor de oxigênio parecem ser mais vermelhas quando comparadas com as demais amostras (Figura 6). Essa situação se inverte no decorrer do período de estocagem (Figura 7). 
Figura 5- Variação do valor de $\mathrm{a}^{*}$ de lombos de cordeiro armazenados em atmosfera modificada e armazenados sob refrigeração, 30 min após a abertura da embalagem durante todo o período de estocagem.

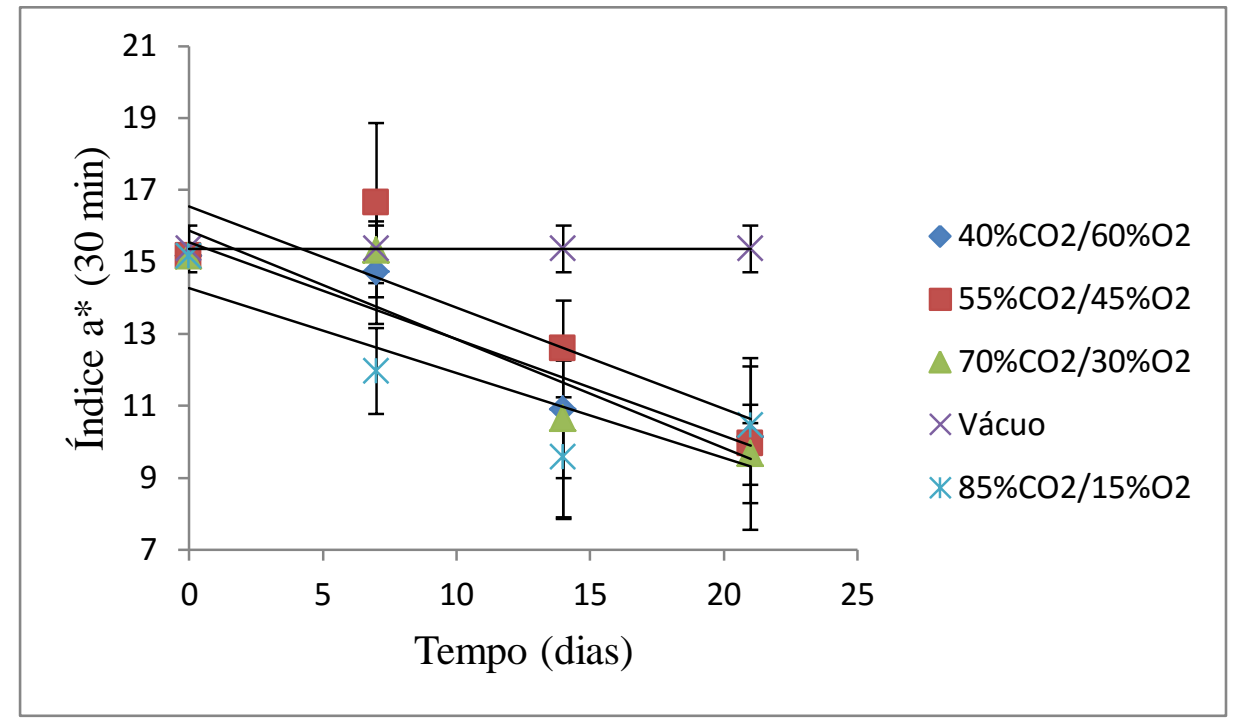

Fonte: Própria autoria

Li et al. (2012) explicam que teores limitados de oxigênio nas embalagens a vácuo resultam em maiores valores relativos de desoximioglobina, que geram coloração roxa. Entretanto, após a abertura da embalagem a desoximioglobina ainda possui a capacidade de se converter em oximioglonia (bloom), causando a formação de coloração vermelha brilhante. Isso explica o fato de amostras embaladas á vácuo exibirem maiores valores de a* após o reblooming no decorrer do experimento. 
Figura 6- Lombos de cordeiros após 30 minutos de exposição ao ar atmosférico no primeiro dia de estocagem a $1^{\circ} \mathrm{C}$.

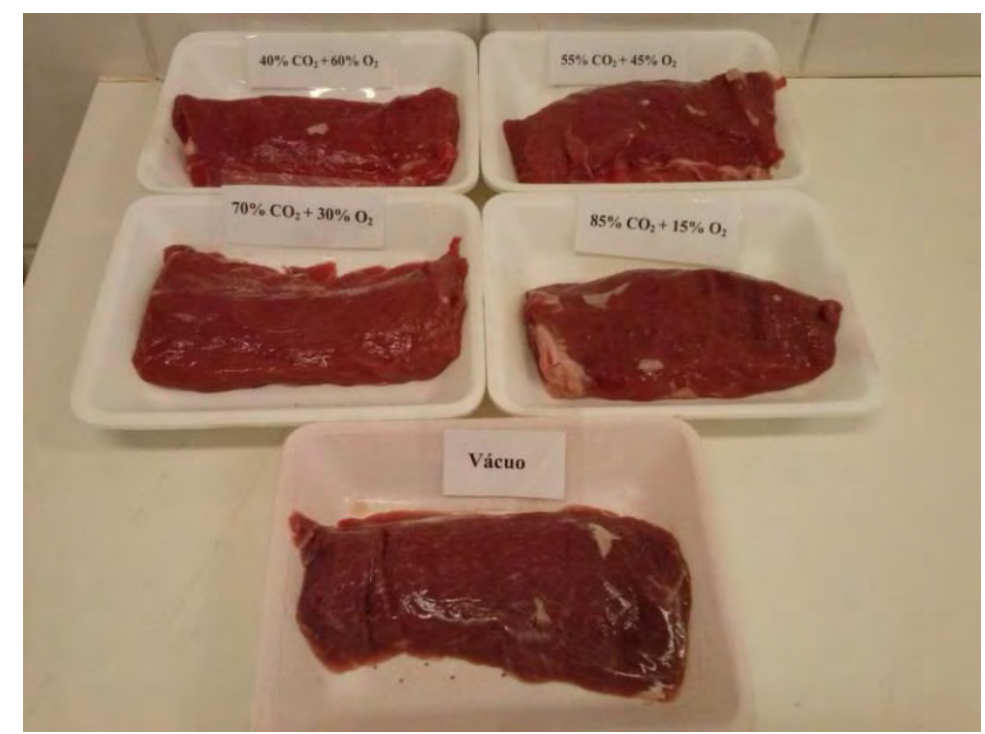

Fonte: Própria autoria

Figura 7- Lombos de cordeiros após 30 minutos de exposição ao ar atmosférico no décimo quarto dia de estocagem a $1^{\circ} \mathrm{C}$.

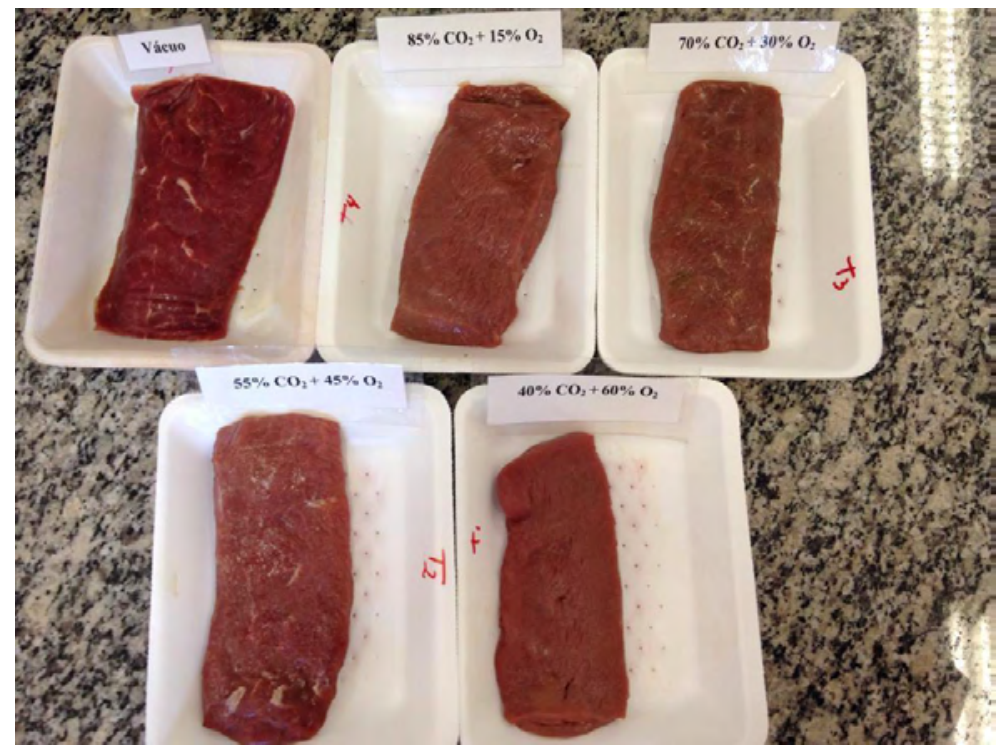

Fonte: Própria autoria

\subsubsection{Potencial hidrogênionico - pH}

Não houve diferença significativa $(p>0,05)$ entre tratamentos para os valores de pH. Variações foram encontradas $(\mathrm{p}<0,05)$ para os diferentes períodos de estocagem 
como apresentado na Figura 8, cujo comportamento pode ser bem explicado por um polinômio quadrático. De maneira geral percebe-se aumento dos valores de $\mathrm{pH}$ ao longo do período da estocagem refrigerada, porém uma leve diminuição na última semana de estocagem. Verificou-se aumento do $\mathrm{pH}$ no início da estocagem, resultante do processo de maturação da carne, que envolve degradação enzimática da estrutura miofibrilar. Segundo Karabagias, Badeka e Kontominas, (2011) o aumento do pH reflete a degradação de proteínas para a produção de aminoácidos livres, os quais conduzem à formação de $\mathrm{NH}_{3}$ e aminas, compostos de reação alcalina.

Contrariamente, Maggioni (2009) realizou um estudo com músculos Longissimus bovinos embalados a vácuo e observou redução no valor de $\mathrm{pH}$ com o aumento do tempo de estocagem. A autora atribuiu esse acontecimento ao desenvolvimento de bactérias lácticas com consequente produção de ácido láctico.

Figura 8- Curva representativa da variação de $\mathrm{pH}$ de lombos de cordeiro armazenados em atmosfera modificada e armazenados sob refrigeração.

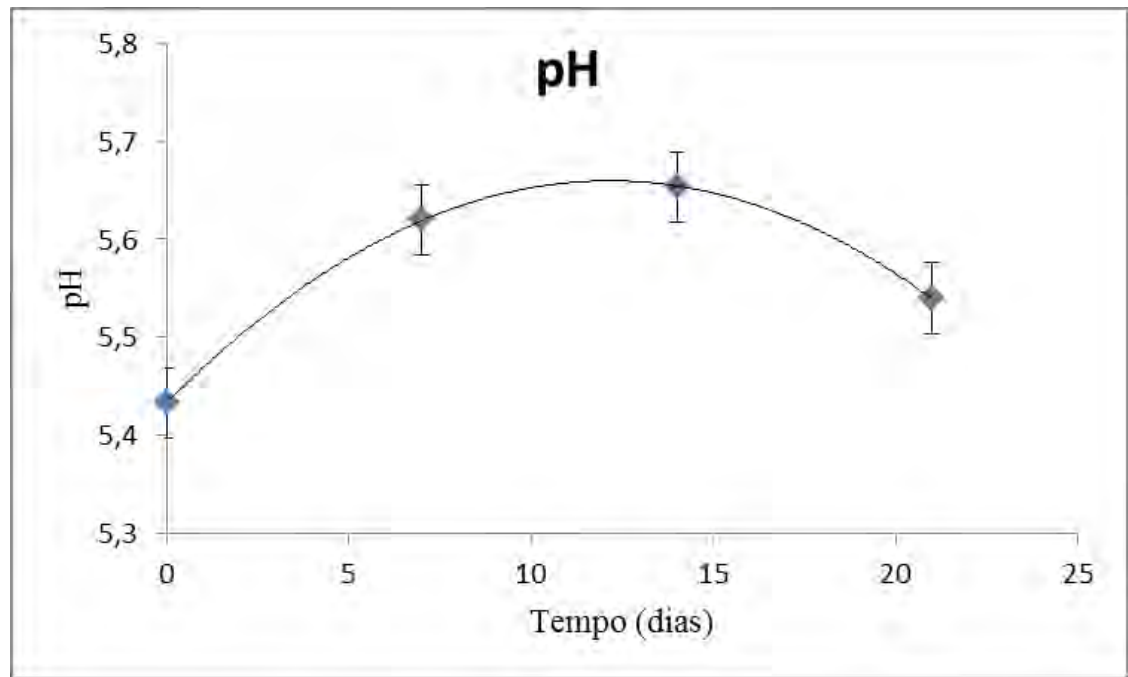

Fonte: Própria autoria 


\subsubsection{Oxidação lipídica}

Os resultados demonstraram diferença significativa $(\mathrm{p}<0,05)$ entre tratamentos e entre os diferentes períodos de estocagem para oxidação lipídica em lombos de cordeiro submetidos às diferentes condições de atmosfera modificada. As curvas para os níveis de oxidação estão expostas na Figura 9.

As amostras com maior índice de oxidação lipídica ao final do experimento $(\mathrm{p}<0,05)$ foram aquelas submetidas à atmosfera contendo $60 \% \mathrm{O}_{2}+40 \% \mathrm{CO}_{2}$. Os resultados dessas amostras são expressos numa curva polinomial. As retas obtidas para os tratamentos contendo $45 \% \mathrm{O}_{2}+55 \% \mathrm{CO}_{2}$ e $30 \% \mathrm{O}_{2}+70 \% \mathrm{CO}_{2}$ mostraram-se muito próximas, com níveis intermediários de oxidação. Uma maior redução do teor de $\mathrm{O}_{2}$ para $15 \%$ ou vácuo não trouxe benefícios, comparativamente aos demais tratamentos.

Figura 9- Índice de TBARS de lombos de cordeiro armazenados em atmosfera modificada e armazenados sob refrigeração, durante o período de estocagem

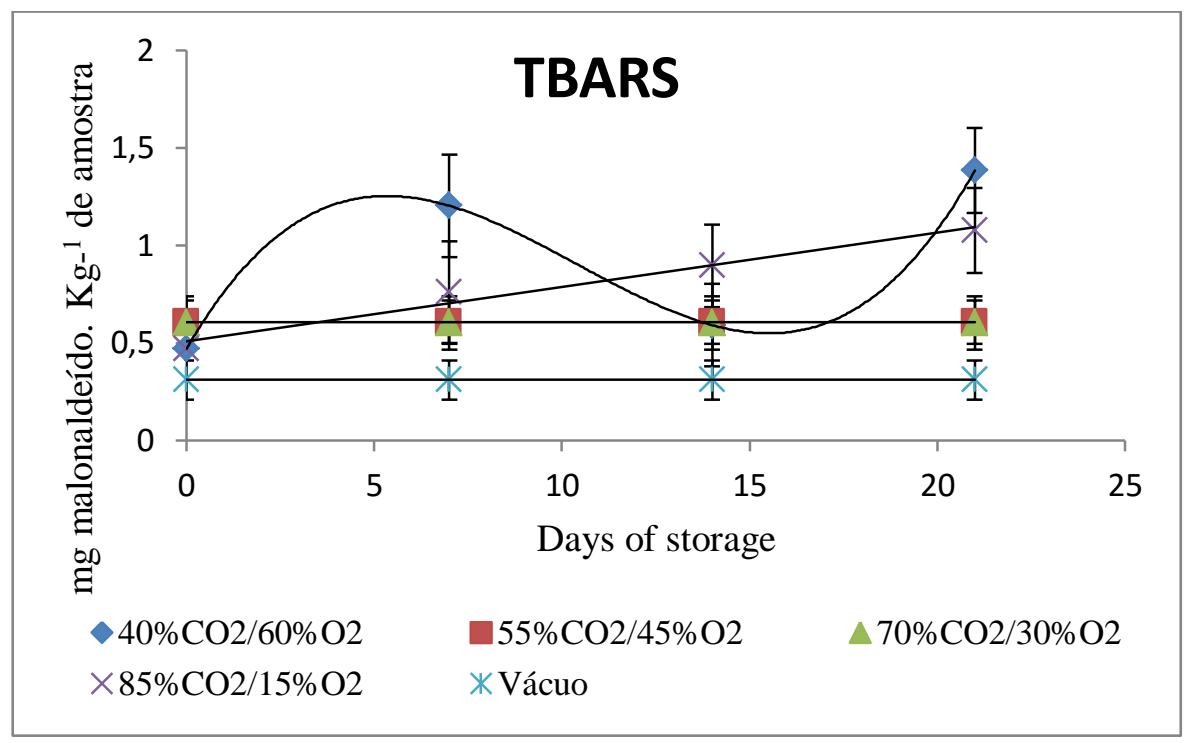

Fonte: Própria autoria.

Nenhum dos tratamentos alcançou o nível de $1,59 \mathrm{mg}$ malonaldeido. $\mathrm{Kg}^{-1}$ de carne ao final do tratamento. Segundo Terra, Cichoski e Freitas, (2006), este é o limite 
considerado seguro para consumo humano. Os melhores resultados foram obtidos para amostras embaladas sob vácuo, onde a ausência de oxigênio manteve as amostras com níveis mais baixos de oxidação. No entanto, não foram encontradas diferenças significativas entre as amostras acondicionados em vácuo, $45 \%$ de $\mathrm{O}_{2}+55 \%$ de $\mathrm{CO}_{2} \mathrm{e}$ $30 \%$ de $\mathrm{O}_{2}+70 \%$ de $\mathrm{CO}_{2}$, indicando que estes tratamentos podem ser aplicados seguramente neste tipo de produto sem que haja aumento significativo do nível de oxidação, quando comparadas com amostras embaladas a vácuo. Redução dos níveis de TBARS ao longo do tempo para um mesmo tratamento, como observado em amostras acondicionadas em $60 \%$ de $\mathrm{O}_{2}+40 \% \mathrm{CO}_{2}$, tem sido explicada por alguns autores. De acordo com Maqsood e Benjakul (2010), o malonaldeído e outros produtos da oxidação de lipídeos são instáveis e podem ser decompostos em formas orgânicas, que não são detectadas pelo teste de TBARS. Saeed, Fawthrop e Howell (1999), explicam que o malonaldeído pode reagir com proteínas, o que também contribui para a diminuição dos valores de TBARS durante o tempo de armazenamento.

De acordo Ladikos e Lougovois (1990) a resistência da carne para o desenvolvimento normal de ranço depende do balanço entre a presença de antioxidantes em tecidos animais, o nível de insaturação e a concentração de ácidos graxos presentes. O antioxidante mais comum em tecido animal é a vitamina $\mathrm{E}$ (tocoferol), que, no entanto, não está totalmente disponível para bloquear a oxidação, devido à natureza não homogênea do tecido animal. O cordeiro contém quantidade relativamente elevada $(57,7 \%)$ de ácidos graxos saturados e baixos níveis de tocoferóis naturais (FORREST et al., 1979). 


\subsubsection{Perda de peso por cocção e força de cisalhamento}

A média geral encontrada para perda de peso por cocção (PAC) entre as amostras de diferentes tratamentos foi $21,85 \%$. Não houve interação significativa $(p>0,05)$ entre as amostras durante o período de estocagem.

Pinkas et al. (1982), estudando cordeiros da raça Katakatchanska, observaram maiores perdas de peso no cozimento no músculo Supraspinatus em animais abatidos com 210 dias de idade, com uma perda de 23,7\%, em relação aos abatidos com 150 de idade, que foi $19,9 \%$. Os autores relacionaram estas variações com a maior quantidade de gordura na carne. Bressan et al. (2001), obtiveram perdas por cocção de $28 \%$, no músculo Longissimus dorsi, ao trabalharem cordeiros das raças Santa Inês e Bergamácia

A capacidade de retenção de água pode afetar a aparência e o comportamento da carne antes e durante o cozimento, respectivamente, também afetando a suculência durante a mastigação (LAWRIE, 2005). Portanto, amostras com menor capacidade de retenção de água possuem mais água extracelular, perdendo-a mais facilmente (maior perda por cocção) sendo, consequentemente, mais duras.

O gráfico representado na Figura 10 demonstra a variação dos resultados de força de cisalhamento ao longo do tempo de armazenamento das amostras.

Para este parâmetro, houve variação significativa apenas com o tempo de estocagem $(p<0,05)$, e não entre tratamentos $(p>0,05)$. Verificou-se redução da força necessária para cortar as amostras devido à maturação da carne. Fregonesi et al. (2014) que trabalhou com lombo de cordeiro embalado à vácuo e tratado com irradiação

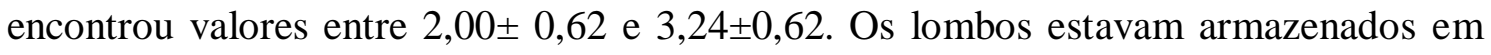
$4^{\circ} \mathrm{C}$ e os autores também não verificaram diferença entre tratamentos. 
Figura 10- Força de cisalhamento de lombos de cordeiro armazenados em atmosfera modificada e armazenados sob refrigeração, medidas durante todo o período de estocagem.

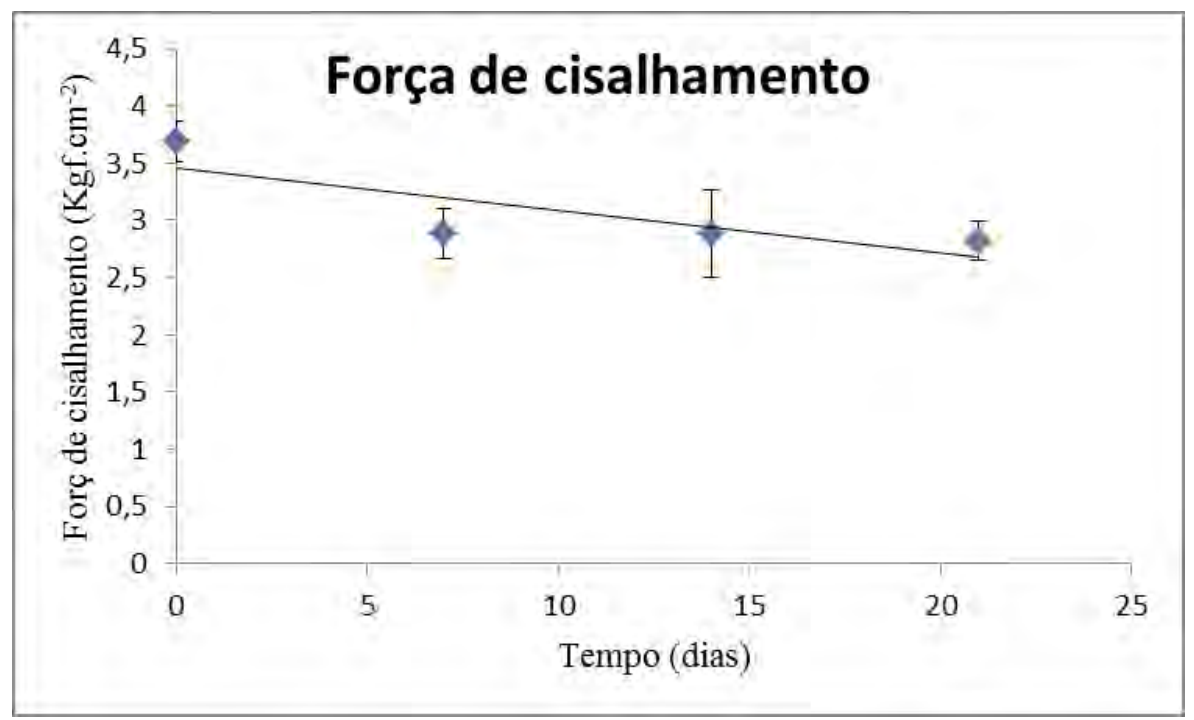

Fonte: Próprio autor

\subsubsection{Análises Microbiológicas}

As análises para contagem de coliformes termotolerantes a $45^{\circ} \mathrm{C}$, estafilococos coagulase positiva e presença de Salmonella, demonstraram que esses microrganismos estavam ausentes em todas as amostras durante todo o período de estocagem. Desta forma, todas as amostras apresentaram-se dentro dos padrões estabelecidos para carne embalada a vácuo, não maturada, dispostos pela resolução RDC 12 de 02 de janeiro de 2001 (BRASIL, 2001). Esta Resolução estabelece contagem máxima de $10^{4} \mathrm{UFC}^{-g^{-1}}$ de amostra para coliformes termotolerantes a $45^{\circ} \mathrm{C}, 3 \times 10^{3} \mathrm{UFC}_{\mathrm{g}}{ }^{-1}$ para estafilococos coagulase positiva e ausência de Salmonela em $25 \mathrm{~g}$ de carne.

De acordo com o ICMSF ("International Commission on Microbiological Specifications on Foods", 1986) o limite de contagem total para cortes de carne é de $10^{7}$ UFC.g ${ }^{-1}$. Para bactérias ácido lácticas (Figura 11) e psicrotróficos anaeróbios (Figura 12) não houve diferença significativa $(p>0,05)$ entre os tratamentos, todas as amostras atingiram o limite máximo no décimo oitavo dia de estocagem. Para psicrotróficos 
aeróbios (Figura 13), houve diferença significativa $(\mathrm{p}<0,05)$ entre os tratamentos. Até aproximadamente o décimo quarto dia de armazenagem refrigerada, as amostras submetidas a vácuo apresentaram maior taxa de desenvolvimento microbiano para esta classe de microrganismos. Embora as curvas obtidas para as amostras acondicionadas em composições gasosas contendo $\mathrm{CO}_{2}$ tenham apresentado comportamento semelhante, verifica-se nitidamente o maior efeito bacteriostático deste gás com o aumento da concentração no espaço livre da embalagem, mesmo com concentrações altas de oxigênio. Este fato é demonstrado pela diferença significativa $(p<0,05)$ encontrada entre os tratamentos e pela diferença de ordem de pelo menos 1 ciclo logarítmico em diversos pontos das diferentes curvas. Amostras submetidas à composição gasosa $15 \% \mathrm{O}_{2}+85 \% \mathrm{CO}_{2}$ atingiram o limite máximo de contagem após 18 dias de armazenamento, as armazenadas sob $30 \% \mathrm{O}_{2}+70 \% \mathrm{CO}_{2}$ e $45 \% \mathrm{O}_{2}+55 \%$ $\mathrm{CO}_{2}$ aos 14 dias, e as armazenadas em atmosferas com $60 \% \mathrm{O}_{2}+40 \% \mathrm{CO}_{2}$ e vácuo atingiram esse limite no décimo primeiro dia de estocagem. Com esses resultados foi possível verificar o efeito do alto teor de gás carbônico na inibição do crescimento microbiano nas amostras.

$\mathrm{O} \mathrm{CO}_{2}$ é um inibidor do crescimento bacteriano e de fungos. Seu modo de ação depende da dissolução do gás no produto embalado. A solubilidade deste gás é indiretamente proporcional a temperatura de armazenamento, logo, baixas temperaturas possuem um efeito sinérgico para a ação bacteriostática do $\mathrm{CO}_{2}$. A condição resultante favorece o crescimento de organismos anaeróbios facultativos incluindo as bactérias ácido láticas, porém em velocidade lenta, atrasando a deterioração da carne (MANTILLA et al., 2010). 
Figura 11- Curva de crescimento de bactérias lácticas de lombos de cordeiro armazenados em atmosfera modificada e armazenados sob refrigeração.

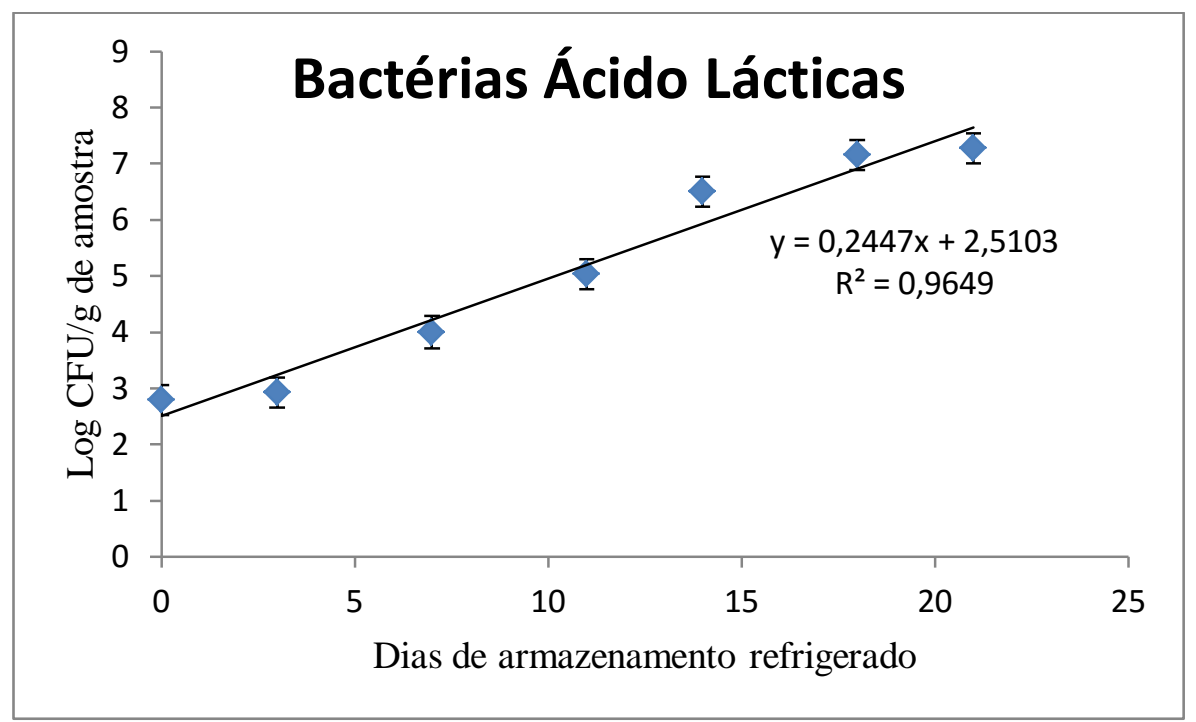

Fonte: Própria autoria

Figura 12- Curva de crescimento de psicrotróficos anaeróbicos de lombos de cordeiro armazenados em atmosfera modificada e armazenados sob refrigeração

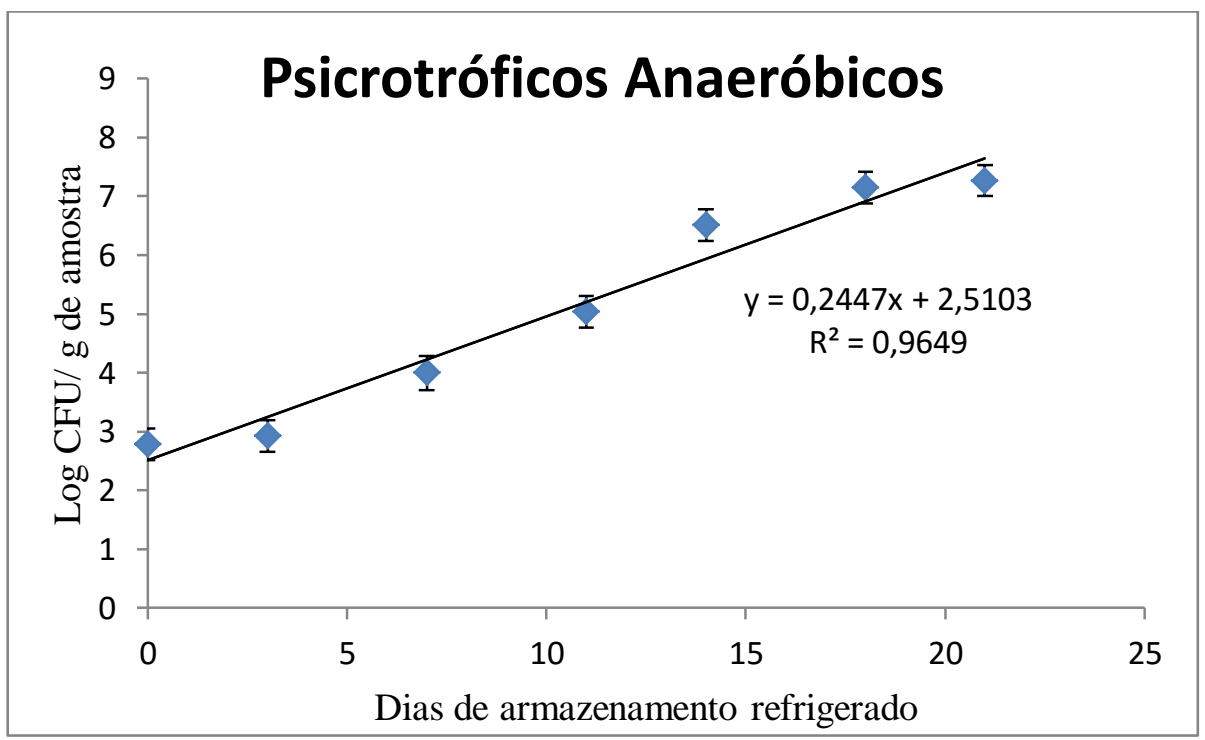

Fonte: Própria autoria. 
Figura 13- Curva de crescimento de psicrotróficos aeróbicos de lombos de cordeiro armazenados em atmosfera modificada e armazenados sob refrigeração.

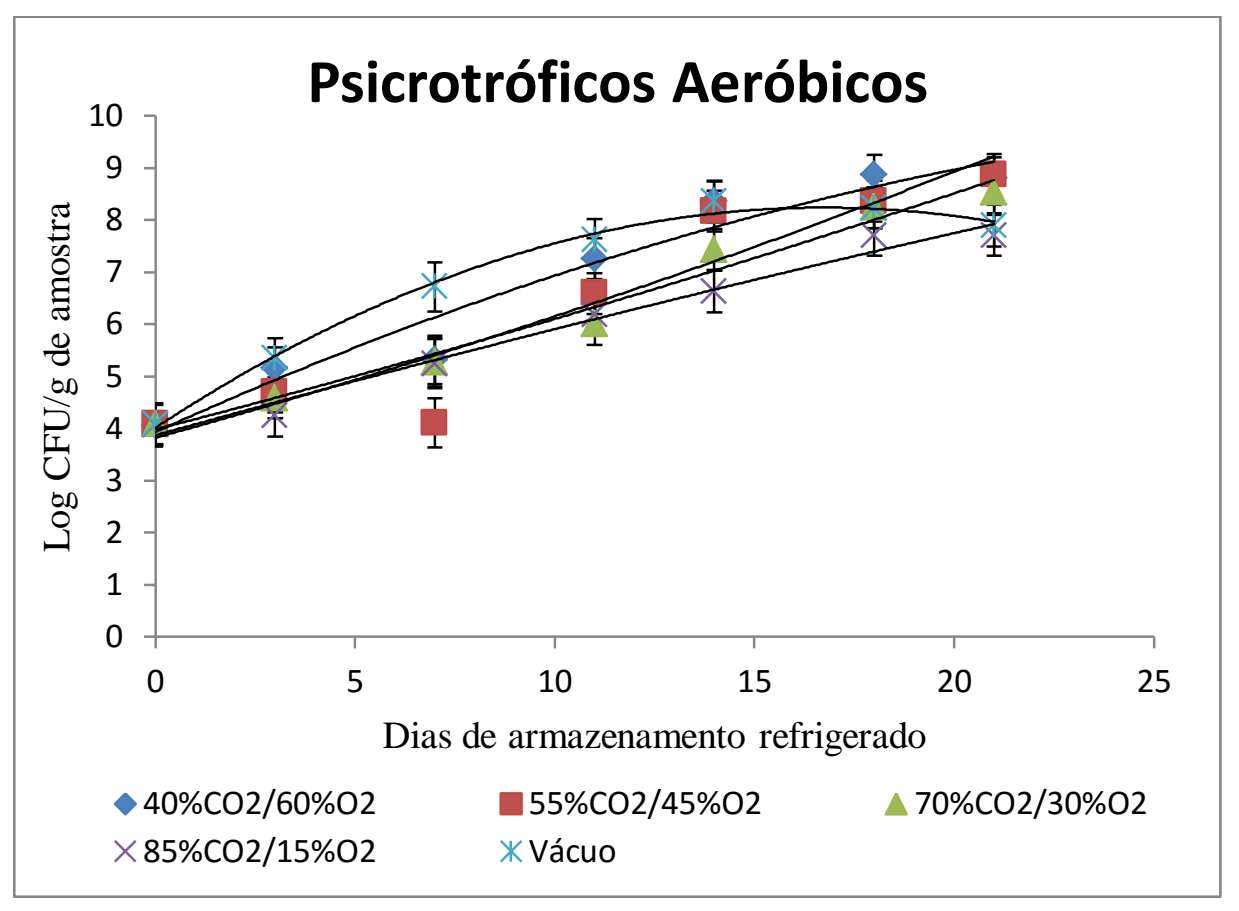

Fonte: Própria autoria

\subsubsection{Análise sensorial}

A análise sensorial foi realizada somente nos tempos de dois e nove dias de estocagem refrigerada em função dos resultados microbiológicos previamente citados. Dessa forma foi garantida a segurança microbiológica da carne para os consumidores. $\mathrm{O}$ intervalo de sete dias entre os testes permitiu a comparação dos resultados entre as amostras dos diferentes tratamentos e entre amostras do mesmo tratamento em diferentes períodos de estocagem.

Os consumidores selecionados para avaliação dos produtos eram, em sua maior parte do sexo feminino, com idade de até 20 anos e formação superior. Esse perfil já era esperado visto que a análise foi realizada no laboratório de Análise Sensorial da Faculdade de Zootecnia e Engenharia de Alimentos - USP, Pirassununga, e os consumidores recrutados eram em sua maioria estudantes. 
Os resultados dos testes afetivos para os tempos dois dias e nove dias de armazenamento estão expostos nas tabelas 3 e 4, respectivamente. O teste afetivo foi conduzido seguindo a escala hedônica de nove pontos que variou do detestei (1) ao adorei (9). Após dois dias de estocagem, não houve diferença significativa ( $p>0,05)$ entre as amostras nos atributos aroma, sabor e qualidade global. Para o atributo textura as amostras armazenadas em atmosfera contendo $15 \% \quad \mathrm{O}_{2}+85 \% \quad \mathrm{CO}_{2}$ diferiram significativamente das amostras embaladas á vácuo. Sendo que as amostras embaladas a vácuo foram consideradas mais macias $(6,96)$. Quanto á suculência amostras embaladas em sistemas com $60 \% \mathrm{O}_{2}+40 \% \mathrm{CO}_{2}$ foram consideradas mais suculentas que amostras embaladas em $30 \% \mathrm{O}_{2}+70 \% \mathrm{CO}_{2}$.

Tabela 3 - Resultado do teste afetivo para amostras de todos os tratamentos no segundo dia de estocagem refrigerada

\begin{tabular}{l|lllll}
\hline $\begin{array}{l}\text { Composição/ } \\
\text { Atributo }\end{array}$ & $60 \% \mathrm{O}_{2}+40 \% \mathrm{CO}_{2}$ & $45 \% \mathrm{O}_{2}+55 \% \mathrm{CO}_{2}$ & $30 \% \mathrm{O}_{2}+70 \% \mathrm{CO}_{2}$ & $15 \% \mathrm{O}_{2}+85 \% \mathrm{CO}_{2}$ & Vácuo \\
\hline Aroma & $6,10^{\mathrm{a}}$ & $5,86^{\mathrm{a}}$ & $5,93^{\mathrm{a}}$ & $6,16^{\mathrm{a}}$ & $5,78^{\mathrm{a}}$ \\
Textura & $6,84^{\mathrm{ab}}$ & $6,78^{\mathrm{ab}}$ & $6,44^{\mathrm{ab}}$ & $6,21^{\mathrm{b}}$ & $6,97^{\mathrm{a}}$ \\
Suculência & $7,14^{\mathrm{a}}$ & $6,95^{\mathrm{ab}}$ & $6,50^{\mathrm{b}}$ & $6,91^{\mathrm{ab}}$ & $6,90^{\mathrm{ab}}$ \\
Sabor & $6,38^{\mathrm{a}}$ & $6,16^{\mathrm{a}}$ & $6,31^{\mathrm{a}}$ & $6,84^{\mathrm{a}}$ & $6,14^{\mathrm{a}}$ \\
Global & $6,69^{\mathrm{a}}$ & $6,45^{\mathrm{a}}$ & $6,52^{\mathrm{a}}$ & $6,76^{\mathrm{a}}$ & $6,62^{\mathrm{a}}$ \\
\hline
\end{tabular}

${ }^{\mathrm{a}}$ letras iguais na mesma linha indicam que as amostras não diferiram significativamente ao nível de $5 \%$.

Fonte: Própria autoria

Após nove dias de estocagem refrigerada houve diferença significativa $(p>0,05)$ em pelo menos uma amostra em todos os atributos, exceto textura. Sendo que amostras armazenadas em atmosfera contendo $15 \% \mathrm{O}_{2}+85 \% \mathrm{CO}_{2}$ tiveram melhor odor $(6,48) \mathrm{e}$ melhor sabor $(6,94)$ que aquelas armazenadas em $45 \% \mathrm{O}_{2}+55 \% \mathrm{CO}_{2}(5,55$ para odor e 5,93 para sabor), esse último tratamento foi também considerado menos suculento $(6,31)$ em comparação com as amostras embaladas em $30 \% \mathrm{O}_{2}+70 \% \mathrm{CO}_{2}(7,03)$. Quanto à qualidade global as amostras embaladas em $15 \% \mathrm{O}_{2}+85 \% \mathrm{CO}_{2}$ e $30 \% \mathrm{O}_{2}+$ 
$70 \% \mathrm{CO}_{2}$ obtiveram classificações significativamente melhores $(\mathrm{p}<0,05)$ que as mostras embaladas em $45 \% \mathrm{O}_{2}+55 \% \mathrm{CO}_{2}$. Neste caso as amostras em $15 \% \mathrm{O}_{2}+85 \% \mathrm{CO}_{2}$ obtiveram maior nota. Em comparação com o vácuo (controle), não foi verificada diferença significativa $(\mathrm{p}<0,05)$ em nenhuma das amostras em todos os parâmetros avaliados após os nove dias de estocagem refrigerada.

Tabela 4 - Resultado do teste afetivo para amostras de todos os tratamentos no nono dia de estocagem refrigerada

\begin{tabular}{l|lllll}
\hline $\begin{array}{l}\text { Composição/ } \\
\text { Atributo }\end{array}$ & $60 \% \mathrm{O}_{2}+40 \% \mathrm{CO}_{2}$ & $45 \% \mathrm{O}_{2}+55 \% \mathrm{CO}_{2}$ & $30 \% \mathrm{O}_{2}+70 \% \mathrm{CO}_{2}$ & $15 \% \mathrm{O}_{2}+85 \% \mathrm{CO}_{2}$ & Vácuo \\
\hline Aroma & $6,10^{\mathrm{ab}}$ & $5,55^{\mathrm{b}}$ & $6,03^{\mathrm{ab}}$ & $6,48^{\mathrm{a}}$ & $6,00^{\mathrm{ab}}$ \\
Textura & $6,62^{\mathrm{a}}$ & $6,45^{\mathrm{a}}$ & $6,95^{\mathrm{a}}$ & $6,69^{\mathrm{a}}$ & $6,97^{\mathrm{a}}$ \\
Sucul & $6,83^{\mathrm{ab}}$ & $6,31^{\mathrm{b}}$ & $7,03^{\mathrm{a}}$ & $6,91^{\mathrm{ab}}$ & $6,86^{\mathrm{ab}}$ \\
Sabor & $6,36^{\mathrm{ab}}$ & $5,93^{\mathrm{b}}$ & $6,50^{\mathrm{ab}}$ & $6,95^{\mathrm{a}}$ & $6,36^{\mathrm{ab}}$ \\
Global & $6,34^{\mathrm{ab}}$ & $6,02^{\mathrm{b}}$ & $6,69^{\mathrm{a}}$ & $6,90^{\mathrm{a}}$ & $6,60^{\mathrm{ab}}$ \\
\hline
\end{tabular}

${ }^{a}$ letras iguais na mesma linha indicam que as amostras não diferiram significativamente ao nível de $5 \%$.

Fonte: Própria autoria

A tabela 5 expressa os resultados do teste visual de ordenação de preferência para os mesmos períodos de estocagem.

Tabela 5 - Resultado do teste visual de ordenação de preferência para amostras de todos os tratamentos nos tempos 2 dias e 9 dias de estocagem.

\begin{tabular}{ccc}
\hline Tratamento/dias & 2 dias & 9 dias \\
\hline $60 \% \mathrm{O}_{2}+40 \% \mathrm{CO}_{2}$ & $190^{\mathrm{b}}$ & $187^{\mathrm{b}}$ \\
$45 \% \mathrm{O}_{2}+55 \% \mathrm{CO}_{2}$ & $178^{\mathrm{b}}$ & $243^{\mathrm{a}}$ \\
$30 \% \mathrm{O}_{2}+70 \% \mathrm{CO}_{2}$ & $229^{\mathrm{a}}$ & $177^{\mathrm{b}}$ \\
$15 \% \mathrm{O}_{2}+85 \% \mathrm{CO}_{2}$ & $122^{\mathrm{c}}$ & $129^{\mathrm{c}}$ \\
Vácuo & $177^{\mathrm{b}}$ & $176^{\mathrm{b}}$ \\
\hline
\end{tabular}

${ }^{a}$ letras iguais na mesma coluna indicam não diferença entre as amostras ao nível de 5\% de confiança. Fonte: Própria autoria

Amostras submetidas a $30 \% \mathrm{O}_{2}+70 \% \mathrm{CO}_{2}$ foram preferidas em relação às demais. Aos dois dias de estocagem este tratamento recebeu notas maiores $(\mathrm{p}<0,05)$ que 
as amostras controle (vácuo). Já no nono dia de estocagem amostras embaladas em 45\% $\mathrm{O}_{2}+55 \% \mathrm{CO}_{2}$ foram preferidas, sendo eu este tratamento também recebeu notas significativamente superiores às amostras embaladas à vácuo.

\subsection{CONCLUSÃO}

A presença de oxigênio na embalagem melhorou a coloração do produto nos primeiros sete dias de armazenamento, após esse período embalagens a vácuo demostraram melhor desempenho na preservação da mioglobina. Apesar do oxigênio promover a oxidação lipídica, alguns tratamentos não mostraram diferença significativa em relação ao vácuo. Quando comparados com a embalagem tradicional (vácuo) um aumento da validade foi conseguido para as amostras embaladas em ATM, as quais estavam em condições microbiológicas seguras para consumo por 14 ou 18 dias a depender o tratamento empregado.

Levando em consideração a segurança microbiológica do alimento, sistemas com 85\% de gás carbônico são indicadas para utilização, visto que foram capazes de preservar o produto por maior tempo. O vácuo continua sendo o melhor tratamento em termos de preservação de cor e oxidação lipídica. 


\section{REFERÊNCIAS}

BONAGURIO, S. et al. Composição centesimal de cordeiros Santa Inês puros e mestiços com Texel abatidos com diferentes pesos. In: SIMPÓSIO LATINO AMERICANO DE CIÊNCIA DE ALIMENTOS, 4., 2001, Campinas. Anais...Campinas: UNICAMP, 2001. p.175.

BRASIL. Leis, decretos, etc. Resolução RDC n⿳ 12, 02 de jan. 2001 da Agência Nacional de Vigilância Sanitária. Aprova o Regulamento Técnico sobre Padrões Microbiológicos para Alimentos. Diário Oficial da União, Brasília, 10 jan. 2001, Seção 1, p.45-47.

BRASIL. ANVISA. Agência Nacional de Vigilância Sanitária. Resolução RDC no 185, de 22 de outubro de 2001. Regulamento Técnico sobre os Padrões Microbiológicos para Alimentos. ANVISA Publicações Eletrônicas, 2001.

BRESSAN, M. C. et al. Efeito do peso ao abate de cordeiros Santa Inês e Bergamácia sobre as características físico-químicas da carne. Revista Ciência e Tecnologia de Alimentos, Campinas, v. 21, n. 3, p. 293 303, 2001.

BRESTER, G. International lamb profile. Agricultural Marketing Resource Center (AgMRC), 2012. Disponível em http://www.agmrc.org/commodities_products/livestock/lamb/international-lamb-profile/\# Acesso em 25 ago. 2015.

CAMO, J.; BELTRÁN, J.A.; RONCALÉS, P. Extension of the display life of lamb with active packaging. Meat Science, Amsterdam, v. 80, p. 1086-1091, 2008.

DEVLIEGHERE, F.; DEBEVERE, J.; IMPE, J. V. Concentration of carbon dioxide in the water-phase as a parameter to model the effect of a modified atmosphere on microorganisms. International Journal of Food Microbiology, Amsterdam, v.43, p. 105-113, 1998.

FERNANDES, R. P. P. et al. Stability of lamb loin stored under refrigeration and packed in different modified atmosphere packaging systems. Meat Science, Amsterdam, v. 96, p. 554-561, 2014.

FERREIRA, V. L. P., et al. Análise Sensorial: Testes discriminativos e afetivos. Campinas SBCTA, 2000. 127p (Manual: Série Qualidade).

FREGONESI, R.P., et al. Irradiated vacuum-packed lamb meat stored under refrigeration: Microbiology, physicochemical stability and sensory acceptance. Meat Science, Amsterdam, v. 97, p. 151-155, 2014.

JAKOBSEN, M.; BERTELSEN, G. Colour stability and lipid oxidation of fresh beef. Development of a response surface model for predicting the effects of temperature, storage time, and modifed atmosphere composition. Meat Science, Amsterdam, v. 54, p. 49-57, 2000. 
JAKOBSEN, M.; BERTELSEN, G. The use of CO2, in packaging of fresh red meats and its effect on chemical, quality changes in the meat: a review. Journal of Muscle Foods, Trumbull, v.13, p.143-168, 2001.

JAYAS, D.S.; JEYAMKONDAN, S. Modified atmosphere storage of grains meats fruits and vegetables. Biosystems Engineering, London, v.82, p.235-251, 2002.

JEREMIAH, L. E. Packaging alternatives to deliver fresh meats using short- or longterm distribution. Food Research International, Kidlington, v. 34, p. 749-772, 2001.

KARABAGIAS, I., BADEKA, A., KONTOMINAS, M.G. Shelf life extension of lamb meat using thyme or oregano essential oils and modified atmosphere packaging. Meat Science, Amsterdam, v. 88, p. 109-116, 2011.

KANNER, J., HAREL, S.; JAFFE, R. Oxidative Processes in Meat and Meat Products: Quality Implications. Meat Science, Amsterdam, v. 36, p. 169-189, 1994.

KENNEDY, C.; BUCKLEY, D.J.; KERRY, J.P. Display life of sheep meats retail packaged under atmospheres of various volumes and compositions. Meat Science, Amsterdam, v. 68, p. 649-658, 2004.

KIM, Y.H. et al. High-oxygen modified atmosphere packaging system induces lipid and myoglobin oxidation and protein polymerization. Meat Science, 85, 759-767, 2010.

KIM, Y.H.B. et al. Effect of forage and retail packaging types on meat quality of longterm chilled lamb loins. Journal of Animal Science, Champaign, v. 91, p. 5998-6007, 2013.

LAWRIE, R. A. Ciência da carne. 6.ed. Porto Alegre: Artmed, 2005.

LEÃO, A. G. et al. Características nutricionais da carne de cordeiros terminados com dietas contendo cana-de-açúcar ou silagem de milho e dois níveis de concentrado.

Revista Brasileira de Zootecnia, Viçosa, v.40, n.5, p.1072-1079, 2011.

LI, X. et al. Influence of vacum skin packaging on color stability of beef longissimus lomborum compared with vacuum and high-oxygen modified atmosphere packaging. Meat Science, Amsterdam, v. 92, p. 604-609, 2012.

LIRA, G.M. et al. Avaliação da oxidação lipídica em carne-de-sol. Higiene Alimentar, Mirandópolis, v. 14, n. 68, p. 66- 69, 2000.

MAQSOOD, S.; BENJAKUL, S. Preventive effect of tannic acid in combination with modified atmospheric packaging on the quality losses of the refrigerated ground beef.

Food Control, Kidlington, v. 21, p. 1282-1290, 2010.

MEILGAARD, M; CIVILLE G. V.; CARR, B. T. Sensory evaluation techniques. Boca Raton: CRC Press, 1991, 394 p. 
PARRY, R. T. Envasado de los alimentos en atmósfera modificada. Madrid(España): A Madrid Vicent, p.13-31, 1993.

PINKAS, A.I.; MARINOVA, P.; TOMOV, I. et al. Influence of age at slaughter, rearing technique and pre-slaughter treatmenton some quality traits of lamb meat. Meat Science, Amsterdam, v. 6, p.245-255, 1982.

ROSA, G.T. et al. Composição tecidual da carcaça e de seus cortes e crescimento alométrico do osso, músculo e gordura da carcaça de cordeiros da raça Texel. Acta Scientiarum, Maringá, v.24, n.4, p.1107-1111, 2002.

SILVA SOBRINHO, A.G. Criação de ovinos. Jaboticabal: Funep, 2001. 302p.

SOUZA, X.R. et al. Sexo e peso ao abate sobre a composição centesimal da carne de cordeiros do cruzamento Santa Inês e Bergamácia. In: SIMPÓSIO LATINO

AMERICANO DE CIÊNCIA DE ALIMENTOS, 4., 2001, Campinas.

Anais... Campinas: UNICAMP, 2001 p.293.

TERRA, N. N., CICHOSKI, A. J., FREITAS, R. J. S. Valores de nitrito e TBARS durante o processamento e armazenamento da paleta suína curada, maturada e fermentada. Ciência Rural, Santa Maria, v. 36, n. 3, p. 965-970, 2006.

VYNCKE, B. W. Direct determination of the thiobarbituric acid value in trichloracetic acid extracts of fish as a measure of oxidative rancidity. Fette Seifen Anstritchmittel, Leinfelden, v. 72, n. 12, p. 1084-1087, 1970.

ZAPATA, J. F.F. NOGUEIRA, C. M., SEABRA, L. M. J. Composição centesimal e lipídica da carne de ovinos do nordeste brasileiro. Ciência Rural, Santa Maria, v. 31, n 4, p 691-695, 2001. 
3. EFEITO DO PROCESSAMENTO EM ALTA PRESSÃO SOBRE PROPRIEDADES FISICO-QUÍMICAS E MICROBIOLÓGICAS DE CARNE BOVINA MARINADA COM REDUZIDO TEOR DE SAL 


\section{RESUMO}

Processamento em alta pressão (HPP) é uma das tecnologias mais recentes que têm mostrado grande potencial na fabricação de produtos cárneos com teor de sódio reduzido. $\mathrm{O}$ objetivo deste trabalho foi avaliar o efeito da alta pressão aplicada em diferentes níveis na inativação de Listeria innocua e Enterococcus faecium inoculados em músculo Longissimus lumborum bovino, marinado com diferentes teores de ácido cítrico e $\mathrm{NaCl}$, bem como sua influência sobre as propriedades físico-químicas desta carne. As amostras foram inoculadas com $10^{6}-10^{7} \mathrm{UFC} / \mathrm{g}$ de L. innocua e E. faecium e marinadas com soluções em diferentes concentrações de $\mathrm{NaCl}$ (1 a 2\%), ácido cítrico (1 e $2 \%$ ) e especiarias durante 18 horas e tratada com alta pressão nos seguintes níveis: zero (Controle), 300, 450 e $600 \mathrm{MPa}$ ). Soluções não-pressurizados não foram suficientes para reduzir a carga microbiana inicial nas amostras, mas com a combinação de alta pressão houve redução nas contagens microbianas. O tratamento com $2 \%$ ácido $+2 \%$ de sal foi o mais eficaz para todas as pressões aplicadas para ambas as bactérias. Nenhuma mudança significativa foi observada na atividade da água das amostras, que se manteve em 0,98, mas a maior concentração de ácido cítrico levou a um pH mais baixo e a menor oxidação de lipídeos após 14 dias de armazenamento sob refrigeração. O uso de 600MPa causou um aumento na dureza da carne. Os resultados mostraram que a HPP foi capaz de produzir um produto seguro, quando a concentração de sódio foi reduzida.

Palavras-chave: Inativação de bactérias, marinação, processo não térmico, saudabilidade. 


\begin{abstract}
High pressure processing (HPP) is one of the newer technologies that have shown great potential for manufacturing meat products with reduced sodium content. The aim of this project was to evaluate the effect of HPP applied at different levels in inactivation of Listeria innocua and Enterococcus faecium inoculated in marinated Longissimus lumborum muscle with reduced sodium content as well as its influence on the physical-chemical properties of the meat. Samples were inoculated with $10^{6}-10^{7} \mathrm{UFC} / \mathrm{g}$ of L. innocua and E. faecium and marinated with solutions in different concentrations of $\mathrm{NaCl}(1$ and 2\%), citric acid (1 and 2\%) and spices for 18 hours and treated with high pressure $(0,300,450$ and $600 \mathrm{MPa})$. Non-pressurized solutions were not sufficient to reduce initial microbial loads in the samples, but the combination with high pressure caused lower counts. The treatment $2 \%$ salt $/ 2 \%$ citric acid was the most effective for each pressure considered for both bacteria. No significante changes were observed in the water activity of the samples, but samples with higher concentration of citric acid showed lower $\mathrm{pH}$ and lower lipid oxidation after 14 days of storage under refrigeration. The use of $600 \mathrm{MPa}$ caused an increase in the toughness of the meat. The results showed that HPP was able to produce a safe product when the sodium concentration was reduced.
\end{abstract}

Keywords: Inactivation of bacteria, marinating, non-thermal process, healthiness. 


\subsection{INTRODUÇÃO}

O possível papel do sódio no desenvolvimento de hipertensão levou as autoridades reguladoras da saúde pública a recomendarem a redução da ingestão de cloreto de sódio (CREHAN, TROY, BUCKLEY, 2000). Ao mesmo tempo, o aumento da demanda por produtos cárneos com reduzido teor de sal demonstra a tendência dos consumidores em buscar produtos cárneos mais saudáveis. No entanto, o cloreto de sódio $(\mathrm{NaCl})$ é um ingrediente essencial neste tipo de produto, pois afeta fatores tais como, a capacidade de retenção de água (CRA), ligação de gordura e cor (BAK et al., 2012). Além da sua influência sobre o sabor e a textura, o cloreto de sódio tem um efeito bacteriostático relacionado com a sua capacidade de reduzir a atividade de água do alimento (DURANTON et al., 2012).

Devido aos problemas tecnológicos relacionados com a redução de sal, são necessários alguns ajustes para manter a segurança e qualidade do produto. Uma variedade de abordagens foi estudada com a finalidade de reduzir o teor de sódio em alimentos, entre as quais estão a substituição de cloreto de sódio por outros tipos de sal e a variação das técnicas de processamento. O processamento com alta pressão (HPP) é uma das tecnologias mais recentes que têm mostrado grande potencial de aplicação na fabricação de produtos cárneos (GROSSI et al., 2012). Um fator que tem despertado o interesse da indústria para o processamento a alta pressão é a exigência crescente do consumidor por alimentos processados que são semelhantes às respectivas matériasprimas em termos de cor, sabor e textura (CREHAN, TROY, BUCKLEY, 2000).

A carne marinada tem se tornando uma espécie popular de alimentos prontos para cozinhar (ready-to-cook), e uma vez que os consumidores têm buscado produtos com teor reduzido de sal é importante encontrar formas de atender a essa demanda sem 
comprometer a segurança dos alimentos. O uso de alta pressão parece ser uma boa solução para este problema.

Desta forma o objetivo deste trabalho foi avaliar o uso de diferentes pressões em combinação com diferentes níveis de sódio e ácido cítrico na inativação de microrganismos e manutenção das características físico-químicas de contrafilé bovino marinado.

\subsection{MATERIAIS E MÉTODOS}

A carne bovina utilizada nesta pesquisa (Longissimus lumborum) foi comprada de um mercado local em Pullman, WA-USA. Uma concentração de $10^{6}-10^{7}$ UFC / g de produto de Enterococcus faecium (ATCC 8459), e Listeria innocua (ATCC 51742) foi inoculada em porções de $100 \mathrm{~g}$ de carne cortadas em pedaços retangulares. $E$. faecium foi utilizado como um substituto de Salmonella entérica. As amostras foram mantidas em soluções com diferentes concentrações (Tabela 6) de $\mathrm{NaCl}$ (1 e 2\%) e ácido cítrico ( 1 e $2 \%$ ) durante 18 horas a $4^{\circ} \mathrm{C}$ e em seguida tratadas com alta pressão (zero, 300, 450 e $600 \mathrm{MPa}$ ).

Tabela 6 - Concentrações de sal e ácido cítrico em marinadas aplicadas nas amostras de carne

\begin{tabular}{|c|c|c|c|c|}
\hline \multirow[b]{2}{*}{ Tratamentos } & \multicolumn{4}{|c|}{ Pressões aplicadas } \\
\hline & $0 \mathrm{MPa}$ & $300 \mathrm{MPa}$ & 450MPa & 600MPa \\
\hline BSBA & $1 \% \mathrm{NaCl}+1 \%$ A.C & $1 \%$ sal+ $1 \%$ A.C & $1 \% \mathrm{NaCl}+1 \% \mathrm{~A} . \mathrm{C}$ & $1 \% \mathrm{NaCl}+1 \%$ A.C \\
\hline BSAA & $1 \% \mathrm{NaCl}+2 \%$ A.C & $1 \% \mathrm{NaCl}+2 \% \mathrm{~A} . \mathrm{C}$ & $1 \% \mathrm{NaCl}+2 \% \mathrm{~A} . \mathrm{C}$ & $1 \% \mathrm{NaCl}+2 \% \mathrm{~A} . \mathrm{C}$ \\
\hline ASBA & $2 \% \mathrm{NaCl}+1 \%$ A.C & $2 \% \mathrm{NaCl}+1 \%$ A.C & $2 \% \mathrm{NaCl}+1 \%$ A.C & $2 \% \mathrm{NaCl}+1 \%$ A.C \\
\hline ASBA & $2 \% \mathrm{NaCl}+2 \%$ A.C & $2 \% \mathrm{NaCl}+2 \% \mathrm{~A} . \mathrm{C}$ & $2 \% \mathrm{NaCl}+2 \%$ A.C & $2 \% \mathrm{NaCl}+2 \%$ A.C \\
\hline
\end{tabular}


Especiarias foram adicionadas nas seguintes concentrações: $2 \%$ de cebola em pó, $2 \%$ de alho em pó, $1 \%$ de pimenta vermelha esmagada, $0,5 \%$ de pimenta preta em pó. Amostras sem tratamento a alta pressão foram preparadas para avaliar o efeito das soluções na carne. A Figura 14 representa a máquina seladora utilizada na embalagem das amostras e a Figura 15 a máquina de HPP.

Figura 14- Máquina seladora utilizada na embalagens das amostras

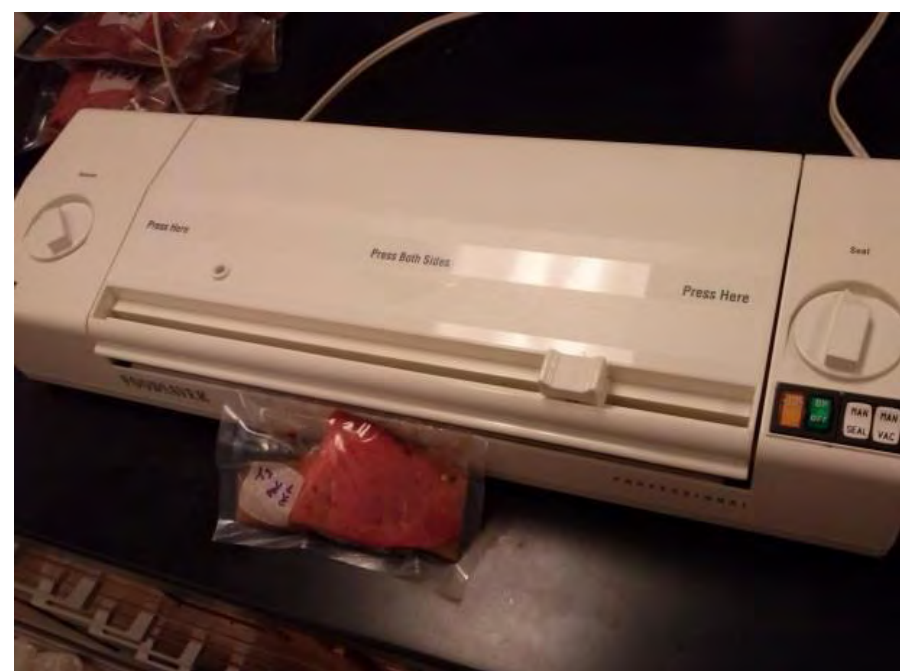

Fonte: Própria autoria.

Figura 15- Equipamento utilizado para processamento em alta pressão das amostras.

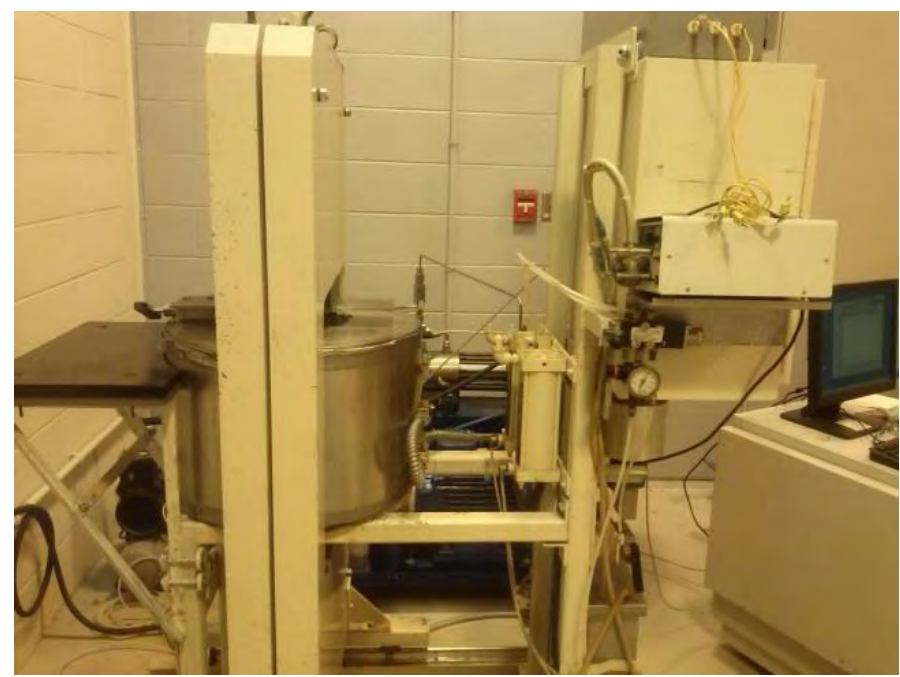

Fonte: Própria autoria. 
Após o HPP, todas as amostras foram submetidas a análises de atividade de água, pH, cor, oxidação lipídica, perda de peso por cocção, força de cisalhamento, contaminação microbiológica e teor de sal. As amostras tratadas com $600 \mathrm{MPa}$ foram analisadas imediatamente após o tratamento e também depois de 14 dias de armazenamento sob refrigeração.

\subsubsection{Microbiologia}

L. innocua foi cultivada por 18-24 horas em caldo Brain Heart Infusion (BHI) a $37^{\circ}$ C. E. faecium foi cultivado durante 10 horas em caldo de soja tríptica (TSB) a $37^{\circ}$ C sob agitação (218 rpm). Ambas as culturas foram cultivadas até atingirem a fase estacionária de crescimento. As culturas foram congeladas em solução de glicerol (20\%) até a sua utilização. Antes da inoculação, as culturas foram descongeladas e misturadas em $100 \mathrm{ml}$ de TSB. A mistura foi dispersa na superfície carne com auxílio de pipeta esterilizada até atingir a concentração de $10^{6} \mathrm{UFC} / \mathrm{g}$ de produto.

Para determinação da quantidade de bactérias nas amostras, $25 \mathrm{~g}$ de produto foram homogeneizados em $225 \mathrm{~mL}$ de água peptonada durante $2 \mathrm{~min}$. Depois disso, foram feitas diluições decimais para posterior plaqueamento. O ágar Enterococcosel TM (Agar Bile Esculin Azide, BD BBL TM) foi utilizado para o plaqueamento de E. faecium e Listeria Oxford Agar Base foi usado para Listeria innocua. As placas foram incubadas a $37^{\circ} \mathrm{C}$ durante $48 \mathrm{~h}$.

\subsubsection{Atividade de água e pH}

A atividade de água foi determinada pelo equipamento AQUALAB (Decagon Devices, Pullman, WA) em triplicata para cada amostra. Os valores de $\mathrm{pH}$ foram tomadas usando um Analisador de $\mathrm{pH}$ (Mettler Toledo) também em triplicata. 


\subsubsection{Cor}

Amostras de cada tratamento, foram submetidas a avaliação de cor através de um colorímetro (Konica Minolta). Valores de luminosidade $\left(\mathrm{L}^{*}\right)$, intensidade de vermelho (a *, vermelho \pm verde) e de amarelo ( $\mathrm{b}^{*}$, amarelo \pm azul) foram medidos de acordo com o sistema CIE Lab, utilizando o iluminante D65 com $10^{\circ}$ de ângulo de observação e abertura de células de $30 \mathrm{~mm}$. As médias de 6 leituras de amostras foram calculadas. A cor também foi medida para a carne crua (sem soluções da marinada e sem HPP).

\subsubsection{Oxidação lipídica}

A oxidação lipídica foi medida por determinação de substâncias reativas ao ácido tiobarbitúrico (TBARS) de acordo com a metodologia descrita por Vyncke et al. (1970). Esta metodologia mede a oxidação de lipídeos através da quantificação de substâncias que reagem com o ácido tiobarbitúrico. Estas substâncias são originadas durante a oxidação dos lipídeos no produto.

\subsubsection{Perdas por cocção e força de cisalhamento}

Inicialmente as amostras foram cozidas em forno $\left(180^{\circ} \mathrm{C}\right)$ até que a temperatura interna atingisse $72{ }^{\circ} \mathrm{C}$, sendo que as amostras foram viradas ao atingirem $36^{\circ} \mathrm{C}$ internos a fim de permitir uniformidade no cozimento. As amostras foram então pesadas antes e após o cozimento e a porcentagem de perda de peso no cozimento (PPC) foi calculada com a equação 2:

$$
\operatorname{PPC}(\%)=\frac{(\text { peso inicial }- \text { peso } \text { final })}{(\text { peso inicial })} \times 100 \quad \text { Equação } 2
$$


Após o cozimento, as amostras foram cortadas em pedaços de 2x1x1 cm e a força de cisalhamento foi medida utilizando um texturômetro (TA-XT2, Stable Micro Systems) com $35 \mathrm{~mm}$ de distância, velocidade de $10 \mathrm{~mm} / \mathrm{s}$, e $5 \mathrm{Kg}$ de peso.

\subsubsection{Teor de sódio}

Espectrometria de absorção atômica foi utilizada para medir o teor de sal nas amostras. Porções de 0,2500 $\mathrm{g}$ de amostra seca foram digeridas usando um sistema digestor com 4,5 $\mathrm{mL}$ de ácido nítrico e $0,5 \mathrm{~mL}$ de peróxido de hidrogênio. Depois de concluída a digestão, as amostras foram diluídas em água pura deionizada para $25 \mathrm{~mL}$ de volume total. O espectrômetro de absorção atômica (SpectrAA 220, Varian) foi

calibrado com soluções de $\mathrm{NaCl}$ em concentrações de 10, 15, 25, 50, 75 e 100 mg.L. $\mathrm{L}^{-1}$ de Na. As leituras foram realizadas em $330,3 \mathrm{~nm}$ de comprimento de onda, em triplicata nas três repetições do experimento (nove medidas para cada tratamento).

\subsubsection{Análise estatística}

Os resultados foram analisados estatisticamente pelo sistema SAS (Sistema de Análise Estatística), por análise de variância e teste de Tukey a 5\%.

\subsection{RESULTADOS E DISCUSSÃO}

\subsubsection{Microbiologia}

Os efeitos de alta pressão, teor de sal e ácido cítrico na sobrevivência de $E$. faecium e L. innocua estão apresentados nas tabelas 7 e 8 respectivamente. 
Tabela 7 - Resultados das contagens de E. faecium (Log10 UFC / g) de amostras de carne submetidas a diferentes níveis de HPP, sal e ácido cítrico.

\begin{tabular}{lccccc}
\hline & \multicolumn{5}{c}{ Pressões aplicadas } \\
\cline { 2 - 6 } Tratamentos & Zero Mpa & $\mathbf{3 0 0 M p a}$ & $\mathbf{4 5 0 M p a}$ & $\mathbf{6 0 0 M P a}$ & $\begin{array}{c}\text { 600MPa 14 } \\
\text { dias }\end{array}$ \\
\hline BSBA & 6,60 & 6,47 & 4,32 & -- & -- \\
BSAA & 6,51 & 6,26 & 3,39 & -- & -- \\
ASBA & 6,56 & 6,40 & 3,46 & -- & -- \\
ASAA & 6,31 & 5,66 & 2,47 & -- & -- \\
\hline
\end{tabular}

-- Nenhuma colônia observada. Baixo teor de sal e baixo teor de ácido (BSBA)/ Baixo teor de sal e alto teor de ácido (BSAA)/ Alto teor de sal e baixo teor de ácido (ASBA)/ Alto teor de sal e alto teor de ácido (ASAA)

Fonte: Própria autoria

Para E. faecium, os resultados mostraram que há efeito sinérgico entre a alta pressão, o sal e o ácido cítrico. Amostras marinadas que não foram submetidas ao tratamento com alta pressão (zero Mpa) não apresentaram redução da carga microbiana inicial, entretanto a combinação de alta pressão com o uso das soluções causou contagens mais baixas. Redução de 1 ciclo log foi alcançado nas amostras tratadas com 300Mpa em soluções com alta concentração de sal e alta concentração de ácido (ASAA), isto é 2\% sal e 2\% ácido cítrico. Quatro e seis reduções logarítmicas foram alcançadas para 450 e $600 \mathrm{MPa}$, respectivamente utilizando a solução ASAA. Comparando-se os tratamentos sob a mesma pressão (450 MPa, por exemplo), o aumento do teor de ácido cítrico foi mais eficaz do que o aumento de sal para inativar $E$. faecium, isto é, redução de 4 ciclos log para ASAA e 3 para ASBA. O tratamento ASAA foi o mais eficaz para todas as pressões estudadas.

Para inativação da Listeria innocua a presença de sal foi mais importante do que a presença de ácido. Esta bactéria também se mostrou mais sensível à alta pressão do que a E. faecium, visto que 450Mpa foi suficiente para redução de até sete ciclos logarítmicos mesmo em baixa concentração de sal. 
Tabela 8 - Resultados das contagens de Listeria innocua (log UFC /g) de amostras de carne submetidos a diferentes níveis de HPP, sal e ácido cítrico.

\begin{tabular}{cccccc}
\hline & \multicolumn{5}{c}{ Pressões Aplicadas } \\
\cline { 2 - 6 } Tratamentos & Zero Mpa & 300Mpa & 450Mpa & 600MPa & $\begin{array}{c}\text { 600MPa 14 } \\
\text { dias }\end{array}$ \\
\hline BSBA & 7,24 & 6,44 & 2,30 & -- & -- \\
BSAA & 7,36 & 5,82 & -- & -- & -- \\
ASBA & 6,65 & 2,54 & -- & -- & - \\
ASAA & 5,85 & $<1.00$ & -- & -- & -- \\
\hline
\end{tabular}

-- Nenhuma colônia observada.

Baixo teor de sal e baixo teor de ácido (BSBA)/ Baixo teor de sal e alto teor de ácido (BSAA)/ Alto teor de sal e baixo teor de ácido (ASBA)/ Alto teor de sal e alto teor de ácido (ASAA).

Fonte: Própria autoria.

Tanto a Listeria innocua quanto o E. faecium são bactérias gram positivas, e de acordo com Torrezan (2003) elas são mais resistentes aos tratamentos a alta pressão do que as gram negativas. Myers et al. (2013) encontraram reduções decimais entre 3,85 e 4,35 na população de Listeria em presunto e carne de peru tratados com cloreto de sódio (1,8\% e 2,4\%), nitrato de sódio (0 e 200ppm) e submetidos a 600Mpa por 180 segundos. Para esses autores o efeito da quantidade de sal também foi maior do que o efeito da quantidade de nitrito na redução da carga microbiana.

\subsubsection{Atividade de água e pH}

Não foram encontradas diferenças significativas $(p>0,05)$ na atividade de água entre os tratamentos para todas as soluções e as pressões aplicadas (dados não mostrados). A atividade de água para todas as amostras foi de 0,98. Isso, pode ser devido à baixa quantidade de $\mathrm{NaCl}$ adicionado às amostras. Horita et al. (2014) desenvolveram salsicha com diferentes concentrações de $\mathrm{NaCl}, \mathrm{KCL}$ e $\mathrm{CaCl}_{2}$. Os autores também não encontraram diferença significativa na atividade de águas das diferentes amostras. O valor médio encontrado foi 0,97. Diferentemente, Ros-Polski et al. (2015), avaliando o efeito da alta pressão e quantidade de sal em carne de frango, 
encontrou diferença significativa entre tratamentos a 5\% de significância. $\mathrm{O}$ valor da atividade de água diminuiu de 1,00 para 0,97 , conforme a concentração de sal aumentou de zero para 2,5\%. Não houve diferença significativa entre amostras pressurizadas e não pressurizadas $(\mathrm{p}>0,05)$.

Em geral foram atingidos valores mais baixos de $\mathrm{pH}$ para as amostras tratadas com 2\% e $2 \%$ sal de ácido cítrico (ASAA) (tabela 9). Houve diferença significativa (p $<0,05)$ entre as amostras ASAA e amostras ASBA. Amostras ASBA apresentaram maiores valores de $\mathrm{pH}$.

Tabela 9 - Os valores de $\mathrm{pH}$ para os diferentes tratamentos e pressões.

\begin{tabular}{lccccc}
\hline & \multicolumn{5}{c}{ Pressões Aplicadas } \\
\cline { 2 - 6 } Tratamentos & Zero Mpa & 300Mpa & 450MPa & 600Mpa & Médias dos Trat. \\
\hline BSBA & $4,91 \pm 0,07$ & $4,88 \pm 0,03$ & $4,88 \pm 0,09$ & $4,84 \pm 0,04$ & $4,87^{\text {ab }} \pm 0,03$ \\
BSAA & $5,0 \pm 0,2$ & $4,9 \pm 0,2$ & $4,86 \pm 0,2$ & $4,9 \pm 0,2$ & $4,93^{\text {ab }} \pm 0,07$ \\
ASBA & $5,0 \pm 0,3$ & $5,1 \pm 0,2$ & $5,1 \pm 0,2$ & $5,1 \pm 0,2$ & $5,06^{\mathrm{a}} \pm 0,06$ \\
ASAA & $4,9 \pm 0,2$ & $4,84 \pm 0,08$ & $4,87 \pm 0,09$ & $4,90 \pm 0,07$ & $4,86^{\mathrm{b}} \pm 0,02$ \\
\hline
\end{tabular}

Médias das Pressões

$4,95^{\mathrm{A}} \pm 0,08 \quad 4,92^{\mathrm{A}} \pm 0,09 \quad 4,9^{\mathrm{A}} \pm 0,1 \quad 4,9^{\mathrm{A}} \pm 0,1$

${ }^{a}$ números com a mesma letra na mesma coluna não são significativamente diferentes

${ }^{A}$ números com a mesma letra na mesma linha não são significativamente diferentes.

Baixo teor de sal e baixo teor de ácido (BSBA)/ Baixo teor de sal e alto teor de ácido (BSAA)/ Alto teor de sal e baixo teor de ácido (ASBA)/ Alto teor de sal e alto teor de ácido (ASAA). Fonte: Própria autoria

Após 14 dias de armazenamento não houve diferença ( $p>0,05$ ) entre as amostras. Goli et al. (2014) encontraram valores de $\mathrm{pH}$ finais iguais a 3,9 e 4,0 para peito de peru marinados em soluções de água e ácido acético, e água, ácido acético e sal, respectivamente. Os autores não encontraram diferença significativa no valor de $\mathrm{pH}$ entre amostras marinadas com e sem sal. Nisiotou et al. (2013) marinou carne bovina inoculada com S. Typhimurium em soluções de vinho tinto. Após 14 dias de armazenamento eles encontraram valores de $\mathrm{pH}$ entre 4,88 e 6,97. 


\subsubsection{Cor}

A média dos valores de $\mathrm{L}^{*}$ para a carne crua (sem marinada e sem HPP) foi 41 \pm 2 . Não houve diferença significativa $(p>0,05)$ entre os tratamentos para todas as soluções e pressões avaliadas (Tabela 10). Após 14 dias de armazenamento, a $4{ }^{\circ} \mathrm{C}$, as amostras tratadas com 600MPa, mostraram diferença significativa $(\mathrm{p}<0,05)$ entre os tratamentos a alta pressão. O maior valor foi encontrado para amostras ASBA e o menor para BSAA (Tabela 11).

Tabela 10 - Valores de $\mathrm{L} *$ para todas as amostras de lombo marinado em diferentes soluções e tratados em diferentes pressões.

\begin{tabular}{cccccc}
\hline \multirow{2}{*}{ Tratamentos } & \multicolumn{5}{c}{ Pressões Aplicadas } \\
\cline { 2 - 5 } & Zero MPa & $\mathbf{3 0 0 M P a}$ & $\mathbf{4 5 0 M p a}$ & $\mathbf{6 0 0 M p a}$ & Média Trat. \\
\hline BSBA & $47 \pm 1$ & $46,7 \pm 0,4$ & $43 \pm 1$ & $47,9 \pm 0,2$ & $46^{\mathrm{a}} \pm 1$ \\
BSAA & $44 \pm 3$ & $43 \pm 1$ & $45 \pm 1$ & $43 \pm 1$ & $43^{\mathrm{a}} \pm 1$ \\
ASBA & $42 \pm 3$ & $42 \pm 3$ & $48 \pm 1$ & $48 \pm 1$ & $45^{\mathrm{a}} \pm 3$ \\
ASAA & $42 \pm 1$ & $43 \pm 1$ & $48 \pm 2$ & $48 \pm 1$ & $44^{\mathrm{a}} \pm 2$ \\
\hline Média das Pressões & $\mathbf{4 4}^{\mathbf{A}} \pm \mathbf{2}$ & $\mathbf{4 3}^{\mathbf{A}} \pm \mathbf{2}$ & $\mathbf{4 6}^{\mathbf{A}} \pm \mathbf{2}$ & $\mathbf{4 6}^{\mathbf{A}} \pm \mathbf{2}$ & \\
\hline
\end{tabular}

${ }^{a}$ números com a mesma letra na mesma coluna não são significativamente diferentes.

${ }^{\mathrm{A}}$ números com a mesma letra na mesma linha não são significativamente diferentes.

Baixo teor de sal e baixo teor de ácido (BSBA)/ Baixo teor de sal e alto teor de ácido (BSAA)/ Alto teor de sal e baixo teor de ácido (ASBA)/ Alto teor de sal e alto teor de ácido (ASAA). Fonte: Própria autoria

Tabela 11 - Comparação entre valores L * para as amostras tratadas com $600 \mathrm{MPa}$ no momento inicial e final do armazenamento.

\begin{tabular}{lccc}
\hline & \multicolumn{2}{c}{ Tempo de armazenamento das amostras tratadas com 600MPa } \\
\cline { 2 - 3 } & Tratamento & Inicial & Após 14 dias \\
\hline BSBA & $47,9 \pm 0,2^{\mathrm{a}}$ & $45^{\mathrm{aAB}} \pm 2$ \\
BSAA & $43^{\mathrm{a}} \pm 1$ & $43,9^{\mathrm{aB}} \pm 0,2$ \\
ASBA & $48^{\mathrm{a}} \pm 1$ & $48,42^{\mathrm{aA}} \pm 0,08$ \\
ASAA & $48^{\mathrm{a}} \pm 1$ & $47^{\mathrm{aAB}} \pm 1$ \\
\hline
\end{tabular}

${ }^{\mathrm{A}}$ números com a mesma letra na mesma coluna não são significativamente diferentes.

${ }^{a}$ números com a mesma letra na mesma linha não são significativamente diferentes.

Baixo teor de sal e baixo teor de ácido (BSBA)/ Baixo teor de sal e alto teor de ácido (BSAA)/ Alto teor de sal e baixo teor de ácido (ASBA)/ Alto teor de sal e alto teor de ácido (ASAA). Fonte: Própria autoria

Para muitos autores (ANDRÉS et al., 2004;. CAMPUS et al., 2008;. YI et al., 2013), HPP normalmente provoca um aumento na valores $L *$ por causa de mudanças 
na proteína. Estas alterações podem ser devido à coagulação da proteína, aumentando a reflexão da luz e a criando uma cor esbranquiçada, ou alterações na estrutura (principalmente despolimerização) criando um aumento da proporção de luz refletida e absorvida pelo material. O presente estudo está de acordo com os resultados encontrados por Cava et al. (2009) que estudou o efeito da HPP a 200 e $300 \mathrm{MPa}$ a $14^{\circ}$ C por 15 ou 30 min em presunto ibérico curado a seco e lombo temperado curado seco. Para ambos, pernil e lombo, nenhuma mudança em $\mathrm{L} *$ ou $\mathrm{b} *$ foi encontrada devido a HPP.

No caso de carne e seus derivados o valor de a* é um dos parâmetros mais importantes a serem avaliados. Quanto maior for o valor a* mas elevada é a intensidade da cor vermelha observada, o que é um atributo importante do ponto de vista do consumidor. Neste experimento, as amostras tratadas com soluções BSBA mostraram valores $\mathrm{a}^{*}$ significativamente $(\mathrm{P}<0,05)$ mais baixos do que as outras amostras (Tabela 12).

Tabela 12 - Intensidade e vermelho ( $\mathrm{a}^{*}$ ) medido para lombo bovino marinado com diferentes soluções e tratados com diferentes pressões

\begin{tabular}{lccccc}
\hline & \multicolumn{5}{c}{ Pressões Aplicadas } \\
\cline { 2 - 6 } Tratamentos & Zero MPa & $\mathbf{3 0 0 M p a}$ & $\mathbf{4 5 0 M p a}$ & $\mathbf{6 0 0 M p a}$ & Média Trat \\
\hline BSBA & $5 \pm 1$ & $5 \pm 1$ & $5,3 \pm 0,9$ & $5 \pm 1$ & $5,2^{\mathrm{a}} \pm 0,1$ \\
BSAA & $6,7 \pm 0.3$ & $6,8 \pm 0,3$ & $6 \pm 1$ & $5,9 \pm 0,4$ & $6,4^{\mathrm{b}} \pm 0,4$ \\
ASBA & $8 \pm 1$ & $6,1 \pm 0,7$ & $6,5 \pm 0,5$ & $6 \pm 1$ & $6^{\mathrm{b}} \pm 1$ \\
ASAA & $5,6 \pm 0,8$ & $6 \pm 1$ & $5,9 \pm 0,6$ & $6,1 \pm 0,6$ & $5,9^{\mathrm{ab}} \pm 0,9$ \\
\hline Médias das pressões & $\mathbf{6}^{\mathbf{A}} \pm \mathbf{1}$ & $\mathbf{6 , 1}^{\mathbf{A}} \pm \mathbf{0 , 7}$ & $\mathbf{6 , 0}^{\mathbf{A}} \pm \mathbf{0 , 5}$ & $\mathbf{5 , 7 ^ { \mathbf { A } } \pm \mathbf { 0 , 5 }}$ & \\
\hline
\end{tabular}

${ }^{a}$ números com a mesma letra na mesma coluna não são significativamente diferentes.

${ }^{\text {A }}$ números com a mesma letra na mesma linha não são significativamente diferentes.

Baixo teor de sal e baixo teor de ácido (BSBA)/ Baixo teor de sal e alto teor de ácido (BSAA)/ Alto teor de sal e baixo teor de ácido (ASBA)/ Alto teor de sal e alto teor de ácido (ASAA). Fonte: Própria autoria

Não houve diferença $(p>0,05)$ no parâmetro a* para as amostras tratadas com diferentes pressões (zero, 300, 450 e 600MPa). Após 14 dias de armazenamento, nenhuma diferença foi encontrada em amostras de diferentes marinadas tratadas com $600 \mathrm{MPa}$ (Tabela 13). Estes resultados demonstram que as pressões mais elevadas 
podem ser utilizadas em lombo marinado, sem qualquer perda da cor vermelha, que é um grande avanço para processamento de carne.

Foram encontradas diferenças significativas $(\mathrm{p}<0,05)$ entre as amostras ASBA e ASAA para o valor $\mathrm{b} *$. Amostras ASAA apresentaram o menor $\mathrm{b} *$ e ASBA o maior. O parâmetro $\mathrm{b} *$ indica a intensidade da cor amarelo / azul nas amostras. Não houve diferença $(p>0,05)$ nesse parâmetro em amostras tratadas com diferentes pressões (Tabela 14). Não foram encontradas alterações após 14 dias de armazenamento (Tabela $15)$.

Tabela 13 - Comparação entre os valores a * para as amostras tratadas com $600 \mathrm{MPa}$ no momento inicial e final do armazenamento.

\begin{tabular}{lcc}
\hline & \multicolumn{2}{c}{ Tempo de armazenamento para amostras tratadas com 600Mpa } \\
\cline { 2 - 3 } Tratamento & Inicial & Após 14 dias \\
\hline BSBA & $5^{\mathrm{a}} \pm 1$ & $5,84^{\mathrm{aA}}$ \\
BSAA & $5,9^{\mathrm{a}} \pm 0,4$ & $5,70^{\mathrm{aA}}$ \\
ASBA & $6^{\mathrm{a} \pm 1}$ & $5,96^{\mathrm{aA}}$ \\
ASAA & $6,1^{\mathrm{a}} \pm 0,6$ & $5,14^{\mathrm{aA}}$ \\
\hline${ }^{\mathrm{A}}$ números com a mesma letra na mesma coluna não são significativamente diferentes. \\
${ }^{\mathrm{a}}$ números com a mesma letra na mesma linha não são significativamente diferentes. \\
Baixo teor de sal e baixo teor de ácido (BSBA)/ Baixo teor de sal e alto teor de ácido (BSAA)/ Alto teor de sal e \\
baixo teor de ácido (ASBA)/ Alto teor de sal e alto teor de ácido (ASAA). Fonte: Própria autoria
\end{tabular}

Tabela 14 - Intensidade de cor amarela $\left(b^{*}\right)$ medida para lombo bovino marinado com diferentes soluções e tratados com diferentes pressões

\begin{tabular}{|c|c|c|c|c|c|}
\hline \multirow[b]{2}{*}{ Tratamentos } & \multicolumn{5}{|c|}{ Pressões Aplicadas } \\
\hline & Zero Mpa & 300Mpa & 450Mpa & 600Mpa & Média Trat. \\
\hline BSBA & $15 \pm 1$ & $17 \pm 1$ & $15 \pm 1$ & $16,4 \pm 0,8$ & $15,83^{\mathrm{ab}}$ \\
\hline BSAA & $15,1 \pm 0,9$ & $16 \pm 1$ & $15,7 \pm 0,9$ & $14,6 \pm 0,5$ & $15,46^{\mathrm{ab}}$ \\
\hline ASBA & $17,3 \pm 0,7$ & $16,3 \pm 0,9$ & $17 \pm 1$ & $17 \pm 1$ & $18,33^{\mathrm{a}}$ \\
\hline ASAA & $14 \pm 1$ & $15,5 \pm 0,4$ & $15,6 \pm 0,9$ & $16 \pm 1$ & $15,27^{\mathrm{b}}$ \\
\hline Média Pressões & $15^{\mathrm{A}} \pm 1$ & $16.1^{A} \pm 0,6$ & $16^{\mathrm{A}} \pm 1$ & $15,9^{A} \pm 0,9$ & \\
\hline \multicolumn{6}{|c|}{ números com a mesma letra na mesma coluna não são significativamente diferentes. } \\
\hline
\end{tabular}

Cava et al. (2009) afirmam que a descoloração provocada pela pressão aparece como um resultado da oxidação da mioglobina ferrosa para mioglobina férrica com uma 
diminuição de valores $a^{*}$. A oxidação também provoca um aumento na proporção de metamioglobina (castanho) em detrimento de oximioglobina (vermelho). A média dos valores de a $*$ para a carne crua (sem marinada e sem HPP) foi $15 \pm 3$ e foi possível verificar perda da cor vermelha em todas as amostras, pressurizadas ou não, o que indica que as soluções também influenciaram a perda de cor da carne.

Tabela 15 - Comparação entre valores de a * para as amostras tratadas com $600 \mathrm{MPa}$ no momento inicial e final do armazenamento.

\begin{tabular}{lcc}
\hline & Tempo de armazenamento para amostras tratadas com 600Mpa \\
\cline { 2 - 3 } Tratamento & $\mathbf{6 0 0 M p a}$ Inicial & $\mathbf{6 0 0 M P a ~} \mathbf{1 4}$ dias \\
BSBA & $16,4^{\mathrm{a}} \pm 0,8$ & $16,72^{\mathrm{aA}}$ \\
$\mathrm{BSAA}$ & $14,6^{\mathrm{a}} \pm 0,5$ & $15,64^{\mathrm{aA}}$ \\
$\mathrm{ASBA}$ & $17^{\mathrm{a}} \pm 1$ & $17,28^{\mathrm{aA}}$ \\
ASAA & $16^{\mathrm{a}} \pm 1$ & $15,35^{\mathrm{aA}}$ \\
\hline${ }^{\mathrm{A}}$ números com a mesma letra na mesma coluna não são significativamente diferentes. \\
${ }^{\mathrm{a}}$ números com a mesma letra na mesma linha não são significativamente diferentes. \\
Baixo teor de sal e baixo teor de ácido (BSBA)/ Baixo teor de sal e alto teor de ácido (BSAA)/ Alto teor de sal e \\
baixo teor de ácido (ASBA)/ Alto teor de sal e alto teor de ácido (ASAA). Fonte: Própria autoria
\end{tabular}

\subsubsection{Oxidação lipídica}

O efeito dos diferentes tratamentos na oxidação lipídica de contrafilé bovino pode ser visualizado na Tabela 16 e o efeito de 14 dias de armazenamento refrigerado em amostras submetidas a 600MPa são mostrados na Tabela 17.

A fim de avaliar o efeito das soluções na oxidação das amostras é interessante comparar os valores no tempo inicial e ao fim de 14 dias de armazenamento. Comparando-se os resultados na Tabela 16, foram observadas diferenças significativas $(\mathrm{P}<0,05)$ entre BSBA e todos os outros tratamentos. No início da estocagem amostras BSBA apresentaram valores menores de TBARS. No entanto, após 14 dias de armazenamento amostras ASAA mostraram menor aumento dos valores de TBARS que as outras amostras. $\mathrm{O} \mathrm{NaCl}$ é conhecido como um composto pró-oxidante, e, de fato, valores iniciais de TBARS demonstram menor oxidação nas amostras BSBA. 
Tabela 16 - Valores de TBARS das amostras de lombo bovino marinado em soluções com diferentes concentrações de sal e ácido cítrico e tratados com diferentes pressões.

\begin{tabular}{|c|c|c|c|c|c|}
\hline \multirow[b]{2}{*}{ Tratamento } & \multicolumn{5}{|c|}{ Pressões Aplicadas } \\
\hline & Zero Mpa & 300Mpa & 450Мра & 600Mpa & Média Trat \\
\hline BSBA & $0,30 \pm 0,02$ & $0,31 \pm 0,02$ & $0,28 \pm 0,02$ & $0,25 \pm 0,02$ & $0,28^{\mathrm{b}} \pm 0,02$ \\
\hline BSAA & $0,5 \pm 0,1$ & $0,55 \pm 0,04$ & $0,53 \pm 0,03$ & $0,51 \pm 0,03$ & $0,54^{\mathrm{a}} \pm 0,02$ \\
\hline ASBA & $0,5 \pm 0,1$ & $0,5 \pm 0,1$ & $0,5 \pm 0,1$ & $0,68 \pm 0,09$ & $0,55^{\mathrm{a}} \pm 0,02$ \\
\hline ASAA & $0,52 \pm 0,1$ & $0,7 \pm 0,2$ & $0,57 \pm 0,09$ & $0,58 \pm 0,1$ & $0,58^{\mathrm{a}} \pm 0,02$ \\
\hline Média Pressãc & $0,5^{\mathrm{A}} \pm 0,1$ & $0,5^{\mathrm{A}} \pm 0,1$ & $0,5^{\mathrm{A}} \pm 0,1$ & $0,5^{\mathrm{A}} \pm 0,1$ & \\
\hline
\end{tabular}

${ }^{a}$ números com a mesma letra na mesma coluna não são significativamente diferentes

${ }^{\text {A }}$ números com a mesma letra na mesma linha não são significativamente diferentes.

* TBARS (mg malonaldeído. Kg-1)

Fonte: Própria autoria

Tabela 17 - Comparação entre os valores de TBARS (malonaldeído mg kg- ${ }^{1}$.) Para amostras tratadas com $600 \mathrm{MPa}$ no momento inicial e final do armazenamento.

\begin{tabular}{lcc}
\hline & Tempo de armazenamento para amostras tratadas com 600Mpa \\
\cline { 2 - 3 } Tratamento & $\mathbf{6 0 0 M p a ~ I n i c i a l ~}$ & $\mathbf{6 0 0 M P a} 14$ dias \\
BSBA & $0,25^{\mathrm{b}} \pm 0,02$ & $0,85^{\mathrm{aA}} \pm 0,1$ \\
BSAA & $0,51^{\mathrm{b}} \pm 0,03$ & $0,81^{\mathrm{aA}} \pm 0,05$ \\
ASBA & $0,68^{\mathrm{b}} \pm 0,09$ & $0,92^{\mathrm{aA}} \pm 0,1$ \\
ASAA & $0,58^{\mathrm{a}} \pm 0,1$ & $0,69^{\mathrm{aA}} \pm 0,05$ \\
\hline
\end{tabular}

${ }^{\mathrm{A}}$ números com a mesma letra na mesma coluna não são significativamente diferentes.

${ }^{a}$ números com a mesma letra na mesma linha não são significativamente diferentes.

Fonte: Própria autoria

$\mathrm{O}$ efeito pró-oxidante de $\mathrm{NaCl}$ em produtos cárneos é devido à sua capacidade para perturbar a interação entre os íons de ferro com as proteínas e, consequentemente, para deixar uma maior quantidade de íons de ferro livres para interagir com a fração lipídica aumentando a oxidação de lipídeos (KANNER, HAREL, E JAFFE , 1991).

No entanto, o efeito real do $\mathrm{NaCl}$ em produtos cárneos pode ser explicado de diferentes maneiras. Por exemplo, Rhee, Smith, e Terrell (1983) descreveram que o $\mathrm{NaCl}$ estimulou a oxidação lipídica em concentrações baixas, mas a inibiu em concentrações superiores a $2 \%$ em carne de porco moída. O efeito preventivo do ácido cítrico na oxidação pode ser visto na Tabela 17. Amostras ASAA apresentaram menores 
valores de TBARS que os outros tratamentos, além disso todas as outras amostras apresentaram aumento significativo ( $p>0,05)$ no valor de TBARS após os 14 dias de armazenamento, com exceção desse tratamento.

Alguns ácidos podem reduzir a oxidação de lípideos. Toomik et al. (2012), avaliaram a oxidação de ácidos graxos poli-insaturados livres durante a marinação de carne de porco, na presença de diferentes acidificantes e constataram que os ácidos cítrico e ascórbico foram capazes de suprimir a oxidação. Ke et al. (2012) relataram seus resultados no músculo Semitendinosus marinado em ácido cítrico. Não houve aumento nos valores de TBARS em amostras durante as $98 \mathrm{~h}$ de armazenamento a $5^{\circ} \mathrm{C}$. Os autores explicam que a inibição da oxidação de lipídeos pelo ácido cítrico pode ser devido à remoção de prooxidantes tais como proteínas heme pelo processo de marinação.

Observando-se os resultados para as amostras logo após o tratamento com HPP, nenhuma diferença significativa ( $p>0,05)$ (Tabela 16) foi observada. HPP geralmente aumenta a oxidação lipídica em produtos cárneos (ANDRES et al., 2004;. CAVA et al., 2002). Campus et al. (2008) afirmam que durante a pressurização ocorre a catálise da oxidação lipídica associada à liberação de ferro não heme e à danos na membrana da célula. No entanto, de acordo com suas pesquisas, as diferenças de oxidação foram observadas especialmente após um dia de armazenamento, onde as amostras controle apresentaram maiores valores de TBARS que as amostras pressurizadas. Mas depois de 45 dias de armazenamento não foram encontradas diferenças (CAMPUS et al., 2008).

\subsubsection{Perda de peso no cozimento e força de cisalhamento}

Os resultados para a perda de peso por cocção são apresentados nas tabelas 18 e 19. De acordo com Ke et al. (2009) muitos estudos mostraram que a capacidade de 
retenção de água e maciez da carne são melhoradas em condições ácidas, abaixo do pH post mortem típico de carne que é 5,2-5,5. No entanto, não houve diferença significativa $(p>0,05)$ para a perda por cocção em nenhuma das amostras em diferentes soluções e pressões tanto no tempo inicial quanto final de armazenamento (14 dias). Os valores encontrados são próximos aos encontrados por Apple et al. (2014), estudando Gluteus medius bovino $(29,5 \pm 0,5)$.

Tabela 18 - Porcentagem de perda de peso por cocção para lombo bovino marinado em diferentes concentrações de sal e ácido cítrico e submetido a diferentes pressões.

\begin{tabular}{|c|c|c|c|c|c|}
\hline \multirow[b]{2}{*}{ Tratamentos } & \multicolumn{5}{|c|}{ Pressões Aplicadas } \\
\hline & Zero Mpa & 300Mpa & 450Mpa & $600 \mathrm{MPa}$ & Média Trat. \\
\hline BSBA & $31 \pm 1$ & $32 \pm 2$ & $32 \pm 3$ & $30 \pm 3$ & $31,82^{\mathrm{a}}$ \\
\hline BSAA & $29 \pm 4$ & $29 \pm 2$ & $30 \pm 2$ & $30 \pm 1$ & $29.50^{\mathrm{a}}$ \\
\hline ASBA & $34 \pm 1$ & $31 \pm 5$ & $34 \pm 1$ & $33 \pm 3$ & $32.93^{\mathrm{a}}$ \\
\hline ASAA & $29 \pm 2$ & $31 \pm 1$ & $29 \pm 1$ & $33,8 \pm 0.8$ & $30.76^{\mathrm{a}}$ \\
\hline Média pressão & $31^{\mathrm{A}} \pm 2$ & $31^{\mathrm{A}} \pm 1$ & $31^{\mathrm{A}} \pm 2$ & $32^{A} \pm 1$ & \\
\hline
\end{tabular}

Tabela 19 - Comparação entre os valores de perda por cocção para amostras tratadas com 600 $\mathrm{MPa}$ no momento inicial e final do armazenamento.

\begin{tabular}{lcc}
\hline & Tempo de armazenamento das amostras tratadas com 600MPa \\
Tratamento & Inicial & Após 14 dias \\
BSBA & $30^{\mathrm{a}} \pm 3$ & $31^{\mathrm{a}^{\mathrm{A}} \pm 2}$ \\
$\mathrm{BSAA}$ & $30^{\mathrm{a}} \pm 1$ & $33^{\mathrm{aA}^{\mathrm{A}} \pm 1}$ \\
$\mathrm{ASBA}$ & $33^{\mathrm{a}} \pm 3$ & $31^{\mathrm{aA}^{\mathrm{A}} \pm 1}$ \\
ASAA & $33,8^{\mathrm{a}} \pm 0.8$ & $33^{\mathrm{aA}^{\mathrm{A}} \pm 1}$ \\
${ }^{\mathrm{A}}$ números com a mesma letra na mesma coluna não são significativamente diferentes. \\
${ }^{\mathrm{a}}$ números com a mesma letra na mesma linha não são significativamente diferentes. \\
Baixo teor de sal e baixo teor de ácido (BSBA)/ Baixo teor de sal e alto teor de ácido (BSAA)/ Alto teor de sal e \\
baixo teor de ácido (ASBA)/ Alto teor de sal e alto teor de ácido (ASAA). Fonte: Própria autoria
\end{tabular}

Os valores de força de cisalhamento são apresentados nas tabelas 20 e 21 . Diferentes soluções não tiveram influência $(p>0,05)$ na textura do produto. No entanto, 
amostras BSAA apresentaram uma tendência para valores mais baixos (ver média dos tratamentos, tabela 20).

Tabela 20 - Valores da força de cisalhamento de lombo bovino marinado em diferentes soluções e tratados com diferentes níveis de pressão.

\begin{tabular}{lccccc}
\hline & \multicolumn{5}{c}{ Pressões Aplicadas } \\
\cline { 2 - 6 } Tratamento & Zero Mpa & $\mathbf{3 0 0 M P a}$ & $\mathbf{4 5 0 M P a}$ & $\mathbf{6 0 0 M p a}$ & Média Trat \\
\hline BSBA & $49 \pm 2$ & $60 \pm 2$ & $56 \pm 2$ & $77 \pm 2$ & $60.8^{\mathrm{a}} \pm 0.9$ \\
BSAA & $55 \pm 1$ & $56 \pm 2$ & $56 \pm 2$ & $83 \pm 3$ & $56.9^{\mathrm{a}} \pm 0.7$ \\
ASBA & $50 \pm 2$ & $59 \pm 2$ & $57 \pm 3$ & $78 \pm 3$ & $60^{\mathrm{a}} \pm 1$ \\
ASAA & $55 \pm 4$ & $54 \pm 2$ & $57 \pm 3$ & $71 \pm 4$ & $60^{\mathrm{a}} \pm 2$ \\
\hline Média Pressões & $\mathbf{5 1}^{\mathbf{B}} \pm \mathbf{2}$ & $\mathbf{5 7}^{\mathbf{B}} \pm \mathbf{1}$ & $\mathbf{5 6}^{\mathbf{B}} \pm \mathbf{2}$ & $\mathbf{7 3}^{\mathbf{A}} \pm \mathbf{1}$ & \\
\hline
\end{tabular}

Média Pressões

${ }^{a}$ números com a mesma letra na mesma coluna não são significativamente diferentes

A números com a mesma letra na mesma linha não são significativamente diferentes.

Baixo teor de sal e baixo teor de ácido (BSBA)/ Baixo teor de sal e alto teor de ácido (BSAA)/ Alto teor de sal e baixo teor de ácido (ASBA)/ Alto teor de sal e alto teor de ácido (ASAA). Fonte: Própria autoria

Tabela 21 - Comparação entre os valores de força de cisalhamento para amostras tratadas com $600 \mathrm{MPa}$ no momento inicial e final do armazenamento.

\begin{tabular}{llc}
\hline & \multicolumn{2}{c}{ Tempo de armazenamento das amostras tratadas com 600MPa } \\
Tratamento & F. de Cisalhamento $(\mathbf{N})$ & $600 \mathrm{MPa} 14$ dias \\
BSBA & $77^{\mathrm{a}} \pm 2$ & $57^{\mathrm{bA}} \pm 2$ \\
BSAA & $79^{\mathrm{a}} \pm 3$ & $73^{\mathrm{aA}} \pm 2$ \\
ASBA & $78^{\mathrm{a}} \pm 3$ & $83^{\mathrm{aA}} \pm 3$ \\
ASAA & $71^{\mathrm{a}} \pm 4$ & $80^{\mathrm{aA}} \pm 2$ \\
\hline${ }^{\mathrm{A}}$ números com a mesma letra na mesma coluna não são significativamente diferentes. \\
${ }^{\mathrm{a}}$ números com a mesma letra na mesma linha não são significativamente diferentes. \\
Fonte: Própria autoria
\end{tabular}

Após 14 dias de armazenamento, somente as amostras com menos sal e menos ácido apresentaram redução na força de cisalhamento $(\mathrm{p}<0,05)$. Houve diferenças significativas $(\mathrm{p}<0,05)$ entre as amostras tratadas com diferentes pressões, sendo que as amostras tratadas com $600 \mathrm{MPa}$ ficaram mais duras que todas as outras. Ke et al. (2009) encontraram 34,8 \pm 1,6 $\mathrm{N}$ no músculo semitendinosus marinado com ácido cítrico mas sem HPP. Grossi et al. (2014) estudaram a modificação de proteínas no músculo semitendinosus de porco tratado com $600 \mathrm{MPa}$ por seis minutos. Eles também encontraram um aumento na dureza para as amostras e explicaram o fato como causado 
pela agregação de proteínas/peptídeos, resultando em endurecimento carne e diminuição da maciez.

\subsubsection{Teor de sódio}

A concentração de sal $(\mathrm{NaCl})$ nas soluções de marinada foi calculado de acordo com a literatura, sendo estudados o valor de $2 \%$ comumente empregado em produtos cárneos e a metade desse valor (1\%). A Tabela 22 mostra os valores do teor de sódio na carne in natura (sem soluções) e na carne marinada.

Tabela 22 - Valores do teor de sódio medido em contrafilé bovino in natura e marinado com diferentes soluções.

\begin{tabular}{cccccc}
\hline $\begin{array}{c}\text { Teor de sódio } \\
(\mathbf{m g} / \mathbf{g})\end{array}$ & \multicolumn{4}{c}{ Soluções aplicadas } \\
\cline { 2 - 5 } & $\begin{array}{c}\text { Carne in } \\
\text { natura }\end{array}$ & BSBA & BSAA & ASBA & ASAA \\
\hline Média* $^{*}$ & 0,94 & 1,8 & 2,1 & 3,8 & 3,9 \\
Desvio Padrão & 0,05 & 0,1 & 0,3 & 0,4 & 0,3 \\
\hline
\end{tabular}

*Média de 9 resultados por amostra.

Baixo teor de sal e baixo teor de ácido (BSBA)/ Baixo teor de sal e alto teor de ácido (BSAA)/ Alto teor de sal e baixo teor de ácido (ASBA)/ Alto teor de sal e alto teor de ácido (ASAA). Fonte: Própria autoria

O USDA (Dietary Guidelines for Americans, 2010) recomenda que adultos saudáveis limitem a sua ingestão de sódio para menos de 2.300 miligramas de sódio por dia. No Brasil, o Ministério da Saúde (2006) recomenda um máximo de 2400 miligramas por dia. A carne marinada produzida nesta pesquisa contém uma quantidade muito menor do que isso em 100g. O tratamento BSBA contém 180 mg /100 g e ASBA $380 \mathrm{mg} / 100 \mathrm{~g}$. Para que um alimento seja rotulado como reduzido na quantidade de sódio, ele deve ter pelo menos $25 \%$ a menos de sódio do que um alimento de referência adequado, tendo como base o valore de referencia normalmente consumido, (ou para as refeições e pratos principais, pelo menos, $25 \%$ a menos de sódio por 100 g) (FDA, 2013). Comparando ASBA e BSBA uma redução de 46,9\% foi alcançada em teor de 
sódio para BSBA, o que torna possível rotular este produto como alimento com teor sódio reduzido, de acordo com a FDA (2013).

\subsection{CONCLUSÃO}

O processamento em alta pressão aliado às soluções marinada pode ser considerado um meio eficiente para conservar os produtos cárneos. Mesmo a menor pressão aplicada (300MPa) foi capaz de alcançar 6 reduções decimais para L. innocua quando foi utilizada solução com $2 \%$ de $\mathrm{NaCl}$ e $2 \%$ de ácido cítrico ASAA. O uso de ácido cítrico ajudou a evitar a oxidação nas amostras, mesmo quando foi aplicada a pressão mais elevada (600Mpa).

Os resultados mostram a possibilidade de fabricar produtos cárneos com reduzido teor de sal sem comprometer os principais atributos do produto, trazendo os benefícios de alimentos mais saudáveis. Recomenda-se a realização de análise sensorial em estudos posteriores a fim de avaliar a percepção do consumidor sobre as características sensoriais do produto. 


\section{REFERÊNCIAS}

ANDRES, A. I. et al. High pressure treatment of dry-cured Iberiam ham: Effect on radical formation, lipid oxidation and colour. European Food Research Technology, Heidelberg, v. 219, p. 205-210, 2004.

APPLE, J. K. et al. Color stability and tenderness variations within the gluteus medius from beef top sirloin butts. Meat Science, Amsterdam, v. 96, p. 56-64, 2014.

BAK, K.H. et al. High pressure effect on the color of minced cured restructured ham at different levels of drying, pH, and $\mathrm{NaCl}$. Meat Science, Amsterdam, v. 90, p. 690-696, 2012.

BRASIL, Ministério da Saúde. Secretaria de Atenção à Saúde. Guia alimentar para a população brasileira : promovendo a alimentação saudável / Ministério da Saúde, Secretaria de Atenção à Saúde, . - Brasília : Ministério da Saúde, 2008. 210 p. - (Série A. Normas e Manuais Técnicos).

CAMPUS, M. et al. Effect of high pressure treatment on colour, microbial and chemical characteristics of dry cured loin. Meat Science, Amsterdam, v. 80, p. 1174-1181, 2008.

CAVA, R. et al. Effect of pressure and holding time on colour, protein and lipid oxidation of sliced dry-cured Iberian ham and loin during refrigerated storage. Innovative Food Science and Emerging Technologies, Amsterdam, v. 10, p. 76-81, 2009.

CREHAN, C.M.; TROY, D.J. ; BUCKLEY, D.J. Efects of salt level and high hydrostatic pressure processing on frankfurters formulated with 1.5 and $2.5 \%$ salt. Meat Science, Amsterdam, v. 55 p. 123-130, 2000.

DURANTON, F. et al. Combined use of high pressure and salt or sodium nitrite to control the growth of endogenous microflora in raw pork meat. Innovative Food Science and Emerging Technologies, Amsterdam, v. 16, p. 373-380, 2012.

FDA. Guidance for Industry: A Food Labeling Guide 9- Appendix A: Definitions of Nutrient Content Claims. 2013. Available in < http://www.fda.gov/Food/GuidanceRegulation/GuidanceDocumentsRegulatoryInformat ion/LabelingNutrition/ucm064911.htm> Acess in Sep-20-2015.

GARRIGA, M. et al. Microbial inactivation after high-pressure processing at $600 \mathrm{MPa}$ in commercial meat products over its shelf life. Innovative Food Science and Emerging Technologies, Amsterdam, v. 5, p. 451-457, 2014.

GOLI, T. et al.. Influence of sodium chloride and $\mathrm{pH}$ during acidic marination on water retention and mechanical properties of turkey breast meat. Meat Science, Amsterdam, v. 96, p. 1133-1140, 2014. 
GROSSI, A. et al. Reduction of salt in pork sausages by the addition of carrot fibre or potato starch and high pressure treatment. Meat Science, Amsterdam, v. 92, p.481489, 2012.

GROSSI, A. et al. High pressure treatment of brine enhanced pork semitendinosus: Effect on microbial stability, drip loss, lipid and protein oxidation, and sensory properties. Innovative Food Science and Emerging Technologies, Amsterdam, v. 22, p. 11-21, 2014.

HORITA, C.N. et al. Textural, microstructural and sensory properties of reduced sodium frankfurter sausages containing mechanically deboned poultry meat and blends of chloride salts. Food Research International, Kidlington, v. 66, p. 29-35, 2014.

KANNER, J., HAREL, S.; JAFFE, R. Lipid peroxidation of muscle food as affected by $\mathrm{NaCl}$. Journal of Agricultural and Food Chemistry, Washington, DC, v. 39, n. 6, p. 1017-1021, 1991.

$\mathrm{KE}$, S. et al. Impact of citric acid on the tenderness, microstructure and oxidative stability of beef muscle. Meat Science, Amsterdam, v. 82, p. 113-118, 2009.

LERASLE, M. et al. Assessment of Salmonella and Listeria monocytogenes level in ready-to-cook poultry meat: Effect of various high pressure treatments and potassium lactate concentrations. International Journal of Food Microbiology, Amsterdam, v. 186, p. 74-83, 2014.

MYERS, K. et al. The effect of high hydrostatic pressure, sodium nitrite and salt concentration on the growth of Listeria monocytogenes on RTE ham and turkey. Meat Science, Amsterdam, v. 93, p. 263-268, 2013.

NISIOTOU, A., et al. Effect of wine-based marinades on the behavior of Salmonella Typhimurium and background flora in beef fillets. International Journal of Food Microbiology, Amsterdam, v. 164, p. 119-127, 2013.

O'FLYNN, CC. et al. The application of high-pressure treatment in the reduction of phosphate levels in breakfast sausages. Meat Science, Amsterdam, v. 96, p. 633-639, 2014.

OMANA, D.A.; PLASTOW, G.; BETTI, M. Effect of different ingredients on color and oxidative characteristics of high pressure processed chicken breast meat with special emphasis on use of $\beta$-glucan as a partial salt replacer. Innovative Food Science and Emerging Technologies, Amsterdam, v. 12, p. 244-254, 2011.

RHEE, K.S., SMITH, G.C.; TERRELL, R.N. Effect of reduction and replacement of sodium-chloride on rancidity development in raw and cooked ground pork. Journal of Food Protection, Des Moines, v. 46, n.7, p. 578, 1983.

RHOADES, J. et al. Use of marination for controlling Salmonella enterica and Listeria monocytogenes in raw beef. Food Microbiology, London, v. 36, p. 248-253, 2013. 
ROS-POLSKI, V., et al. Effects of high hydrostatic pressure processing parameters and $\mathrm{NaCl}$ concentration on the physical properties, texture and quality of white chicken meat. Innovative Food Science and Emerging Technologies, Amsterdam, v. 30, p. 31-42, 2015.

TOOMIK, P. et al. The effect of tenderizing acids on linoleic acid oxidation during marination of pork. Meat Science, Amsterdam, v. 92, p. 870-873, 2012.

USDA- United States Department of Agriculture. Food Standards and Labeling Policy Book. Food Safety And Inspection Service, 2005. Disponível em: <http://www.fsis.usda.gov/OPPDE/larc/Policies/Labeling_Policy_Book_082005.pdf> Acesso em: 14 abr. 2015.

VINCKE, W. Direct of the Thiobarbituric Acid Value in Trichlorcetic Acid Extracts of Fish as a Measure of Oxidative Rancidity. Fette Seifen Anstrichmittel, Leifekden, v.72, n.12 p1-84-1087, 1970.

YI, J. et al. High hydrostatic pressure and thermal treatments for ready-to-eat winemarinated shrimp: An evaluation of microbiological and physicochemical qualities.

Innovative Food Science and Emerging Technologies, Amsterdam, v. 20, p. 16-23, 2013.

YUSTE, J. et al. Listeria innocua and aerobic mesophiles during chill storage of inoculated mechanically recovered poultry meat treated with high hydrostatic pressure. Meat Science, Amsterdam, v. 53, p. 251- 257, 1999. 
ANEXO A - Ficha com escala hedônica utilizada no teste de aceitação

Nome:

Data:

Ficha

Você está recebendo uma amostra de CARNE DE CORDEIRO. Por favor, avalie o produto e marque na escala o quanto você gostou ou desgostou das seguintes características:

Número da amostra

\begin{tabular}{|c|c|c|c|}
\hline Número da amostra & & Nota & \\
\hline ESCALA & AROMA & & Comentários: \\
\hline $\begin{array}{l}\text { 1-Detestei } \\
\text { 2-Desqostei }\end{array}$ & TEXTURA & & Comentários: \\
\hline $\begin{array}{l}\text { 3-Desgostei moderadamente } \\
\text { 4-Desgostei ligeiramente }\end{array}$ & SUCULËNCIA & & Comentários: \\
\hline $\begin{array}{l}\text { 5-Nem gostei/nem desgostei } \\
\text { 6-Gostei ligeiramente } \\
\text { 7-Gostei moderadamente }\end{array}$ & SABOR & & Comentários: \\
\hline $\begin{array}{l}\text { 8-Gostei muito } \\
\text { 9-Adorei }\end{array}$ & $\begin{array}{l}\text { QUALIDADE } \\
\text { GLOBAL }\end{array}$ & & Comentários: \\
\hline
\end{tabular}


Anexo B- Ficha de Ordenação de Preferência

Nome:

Data: Ficha

\section{TESTE DE ORDENAÇÃO DE PREFERENCIA}

Por favor, avalie as 5 amostras de carne de cordeiro em relação á aparência global e ordene-as em ordem crescente de preferência

Menos preferida

Mais preferida

Comentários:

Nome:

Data:

Ficha 
Anexo C - Ficha de Recrutamento

Nome:

Data:

Por favor, responda às seguintes questões:

1. Gosta de carne de cordeiro ? Sim $\square \quad$ Não $\square$

2. Indique na escala abaixo quanto de carne de cordeiro você consome em média?

$\square$ Quase sempre (quase todo dia)

$\square$ Muito (3 a 4 vezes por semana)

$\square$ Moderado (1 a 2 vezes por semana)

$\square$ Pouco (menos de uma vez por semana)

$\square$ Quase nunca (menos de uma vez por mês)

Nome:

Data:

Por favor, responda às seguintes questões:

1. Gosta de carne de cordeiro? Sim $\square \quad$ Não $\square$

2. Indique na escala abaixo quanto de carne de cordeiro você consome em média?

$\square$ Quase sempre (quase todo dia)

$\square$ Muito (3 a 4 vezes por semana)

$\square$ Moderado (1 a 2 vezes por semana)

$\square$ Pouco (menos de uma vez por semana)

$\square$ Quase nunca (menos de uma vez por mês)

Nome:

Data:

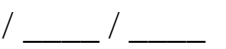

Por favor, responda às seguintes questões:

1. Gosta de carne de cordeiro? Sim $\square$

Não $\square$

2. Indique na escala abaixo quanto de carne de cordeiro você consome em média?

$\square$ Quase sempre (quase todo dia)

$\square$ Muito (3 a 4 vezes por semana)

$\square$ Moderado (1 a 2 vezes por semana)

$\square$ Pouco (menos de uma vez por semana)

$\square$ Quase nunca (menos de uma vez por mês) 
ANEXO D- Ficha de Recrutamento

Nome:

Data:

Sexo:

I

Localidade em que reside: Estado

Município

Idade: $\square$ Até 20 anos $\square$ de 20 a 40 anos $\square$ de 40 a 60 anos $\square$ acima de 60 anos

Escolaridade: $\square$ Nível Fundamental $\square$ Nível Médio $\square$ Superior

Renda Familiar: $\square$ até 5 SM $\square$ de 5 a 10 SM $\square$ de 10 a 20 SM $\square$ mais de 20 SM

Por favor, responda às seguintes questões:

1. Você gosta de carne de cordeiro? Sim $\square \quad$ Nao $\square$

2. Com que freqüência, em média, você consome carne de cordeiro:

$\square$ Quase sempre (1 ou mais vezes por semana)

$\square$ Muito (2 ou 3 vezes por mês)

$\square$ Moderado (pelo menos 1 vez por mês)

$\square$ Pouco (menos de 1 vez por mês)

$\square$ Quase nunca (somente em ocasiões especiais)

3. Com que freqüência, em média, você compra carne (de qualquer espécie) embalada à vácuo?

$\square$ Quase sempre (1 ou mais vezes por semana)

$\square$ Muito ( 2 ou 3 vezes por mês)

$\square$ Moderado (pelo menos 1 vez por mês)

$\square$ Pouco (menos de 1 vez por mês)

$\square$ Quase nunca (somente em ocasiões especiais) 